\title{
JV TASK 59 - DEMONSTRATION OF ACCELERATED IN SITU CONTAMINANT DEGRADATION BY VACUUM-ENHANCED NUTRIENT DISTRIBUTION
}

Final Report

Prepared for:

AAD Document Control

U.S. Department of Energy

National Energy Technology Laboratory

PO Box 10940, MS 921-107

Pittsburgh, PA 15236-0940

Cooperative Agreement No.: DE-FC26-98FT40321

Performance Monitor: Heino Beckert

Prepared by:

Jaroslav Solc

Energy \& Environmental Research Center University of North Dakota 15 North 23rd Street, Stop 9018

Grand Forks, North Dakota 58202-9018 


\section{DISCLAIMER}

This report was prepared as an account of work sponsored by an agency of the United States Government. Neither the United States Government, nor any agency thereof, nor any of their employees makes any warranty, express or implied, or assumes any legal liability or responsibility for the accuracy, completeness, or usefulness of any information, apparatus, product, or process disclosed or represents that its use would not infringe privately owned rights. Reference herein to any specific commercial product, process, or service by trade name, trademark, manufacturer, or otherwise does not necessarily constitute or imply its endorsement, recommendation, or favoring by the United States Government or any agency thereof. The views and opinions of authors expressed herein do not necessarily state or reflect those of the United States Government or any agency thereof.

This report is available to the public from the National Technical Information Service, U.S. Department of Commerce, 5285 Port Royal Road, Springfield, VA 22161; phone orders accepted at (703) 487-4650.

\section{EERC DISCLAIMER}

LEGAL NOTICE This research report was prepared by the Energy \& Environmental Research Center (EERC), an agency of the University of North Dakota, as an account of work sponsored by the U.S. Department of Energy (DOE). Because of the research nature of the work performed, neither the EERC nor any of its employees makes any warranty, express or implied, or assumes any legal liability or responsibility for the accuracy, completeness, or usefulness of any information, apparatus, product, or process disclosed or represents that its use would not infringe privately owned rights. Reference herein to any specific commercial product, process, or service by trade name, trademark, manufacturer, or otherwise does not necessarily constitute or imply its endorsement or recommendation by the EERC. 


\title{
JV TASK 59 - DEMONSTRATION OF ACCELERATED IN SITU CONTAMINANT DEGRADATION BY VACUUM-ENHANCED NUTRIENT DISTRIBUTION
}

\begin{abstract}
The Energy \& Environmental Research Center (EERC) conducted remediation of hydrocarbon-contaminated soils and groundwater at a former Mohler Oil site in Bismarck, North Dakota. The remedial strategy was based on the application of two innovative concepts: 1) design and deployment of the mobile extraction, treatment, and injection units to overcome site limitations associated with urban settings in high-traffic areas and 2) vacuum-controlled nutrient injection within and on the periphery of an induced hydraulic and pneumatic depression.

Combined contaminant recovery since the beginning of the project in June 2003 totals over $13,600 \mathrm{lb}(\sim 6,170 \mathrm{~kg})$ of hydrocarbons, equivalent to 2176 gallons (8236 I) of product. In situ delivery of $1504 \mathrm{lb}(682 \mathrm{~kg})$ of ionic nitrate and $540 \mathrm{lb}(245 \mathrm{~kg})$ of dissolved oxygen translates into further reduction of about $489 \mathrm{lb}(222 \mathrm{~kg})$ of benzene for the same period and provides for long-term stimulation of the natural attenuation process. In addition to contaminant recovered by extraction and reduced by in situ biodegradation, a total of $4136 \mathrm{lb}(1876 \mathrm{~kg}) \mathrm{of}$ oxygen was delivered to the saturated zone, resulting in further in situ reduction of an estimated $1324 \mathrm{lb}(600 \mathrm{~kg})$ of dissolved-phase hydrocarbons. Based on the results of the EERC demonstration, the North Dakota Department of Health approved site abandonment and termination of the corrective action.
\end{abstract}




\section{TABLE OF CONTENTS}

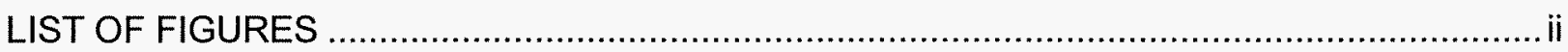

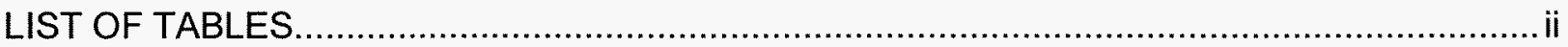

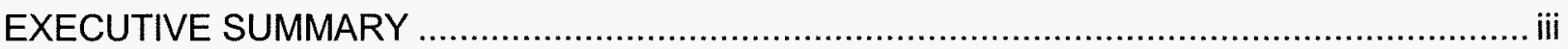

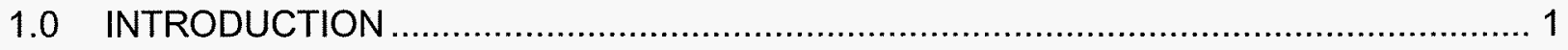

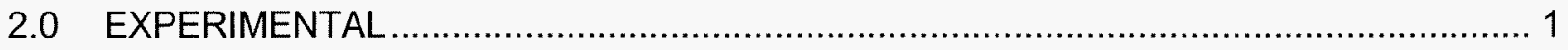

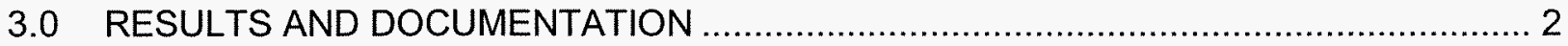

S.1 Site Characteristics.................................................................................... 2

3.1.1 Site Location and Contaminant Release History ....................................... 2

3.1.2 Hydrogeology and Contaminant Transport................................................ 4

3.2 Remediation Systems............................................................................... 4

3.2.1 Extraction, Monitoring, and Injection Well Fields ....................................... 4

3.2.2 Multiphase Extraction and Treatment System ………………………...... 5

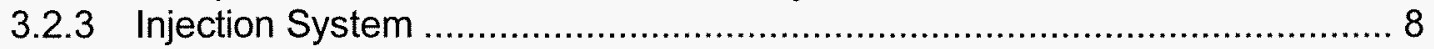

3.3 Contaminant Recovery and Degradation Estimates........................................... 9

3.4 Groundwater Quality Monitoring ........................................................................11

3.4.1 Sampling Program ........................................................................ 11

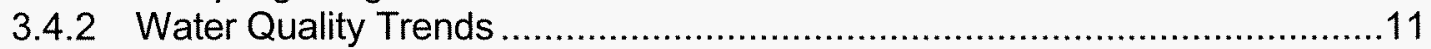

3.5 Technical and Economic Summary and Discussion..........................................12

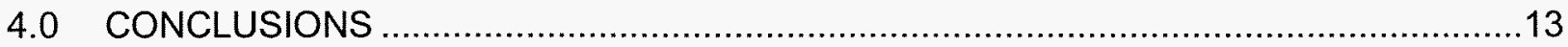

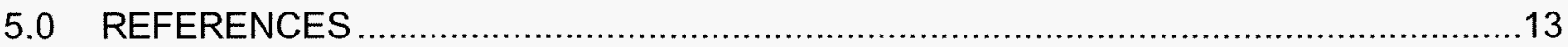

SITE PLAN AND EXTRACTION/INJECTION WELL FIELDS......................................Appendix A

GROUNDWATER TABLE MONITORING - SUMMARY OF DATA .............................Appendix B

RECOVERY AND INJECTION SYSTEMS .......................................................... Appendix C

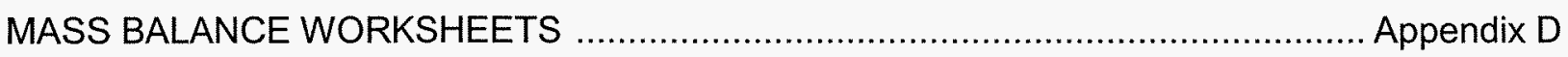
CONTAMINANT RECOVERY - LIQUID PHASE ...................................... Appendix D-1 CONTAMINANT RECOVERY - VAPOR PHASE ....................................... Appendix D-2 INJECTION SYSTEM ....................................................................... Appendix D-3

SUMMARY OF DATA - SYSTEM MONITORING ..................................................Appendix E

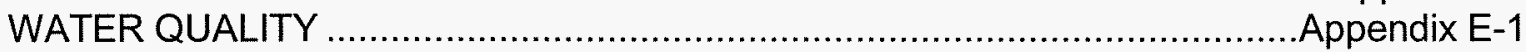

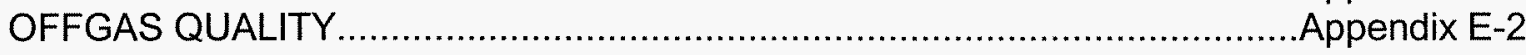

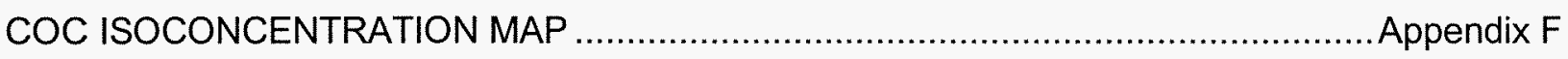

GROUNDWATER QUALITY MONITORING - SUMMARY OF DATA ....................... Appendix G COC IN GROUNDWATER ……...................................................... Appendix G-1 BIODEGRADATION INDICATORS …………………........................ Appendix G-2 


\section{LIST OF FIGURES}

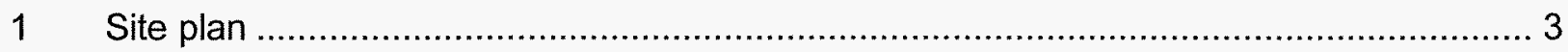

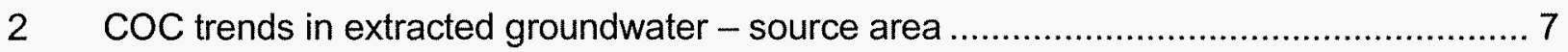

$3 \mathrm{COC}$ trends in extracted groundwater - downgradient area................................. 7

4 Hydrocarbon concentration trends in offgas - source area $2003 \ldots \ldots \ldots \ldots \ldots \ldots \ldots \ldots \ldots . . \ldots \ldots$

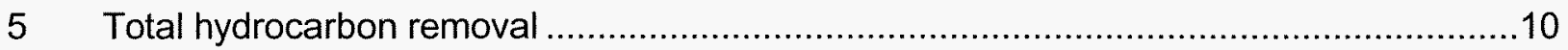

\section{LIST OF TABLES}

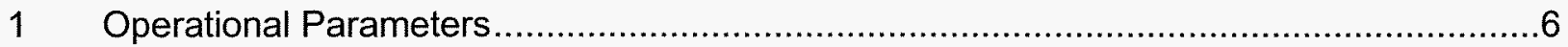

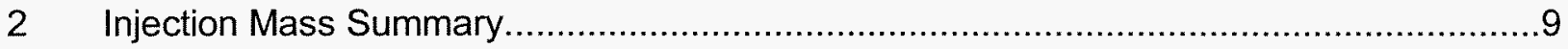

3 MPE System Contaminant Recovery .......................................................... 10

4 Contaminant Recovery/Degradation Breakdown Estimates .....................................11 


\section{JV TASK 59 - DEMONSTRATION OF ACCELERATED IN SITU CONTAMINANT DEGRADATION BY VACUUM-ENHANCED NUTRIENT DISTRIBUTION}

\section{EXECUTIVE SUMMARY}

At the request of the North Dakota Department of Health (NDDH) and the North Dakota Petroleum Tank Release Compensation Fund (NDPTRCF), the Energy \& Environmental Research Center (EERC) conducted remediation of hydrocarbon-contaminated soils and groundwater at a former Mohler Oil site in Bismarck, North Dakota. The remedial strategy was based on the application of two innovative concepts: 1) design and deployment of the mobile extraction, treatment, and injection units to overcome site limitations associated with urban settings in high-traffic areas and 2) vacuum-controlled nutrient injection within and on the periphery of an induced hydraulic and pneumatic depression.

Over $13,600 \mathrm{lb}(\sim 6170 \mathrm{~kg})$ of hydrocarbons, equivalent to 2176 gallons (8236 I) of product, has been recovered from contaminated soils and groundwater since the beginning of the project in June 2003. In situ delivery of $1504 \mathrm{lb}(682 \mathrm{~kg})$ of ionic nitrate and $540 \mathrm{lb}(245 \mathrm{~kg})$ of dissolved oxygen translates into further reduction of about $489 \mathrm{lb}(222 \mathrm{~kg})$ of benzene for the same period and provides for long-term stimulation of the natural attenuation process. In addition to contaminant recovered by extraction and reduced by in situ biodegradation, a total of $4136 \mathrm{lb}(1876 \mathrm{~kg})$ of oxygen was delivered to the saturated zone. By providing necessary electron acceptors, this volume translates into further in situ reduction of an estimated $1324 \mathrm{lb}$ $(600 \mathrm{~kg})$ of dissolved-phase hydrocarbons.

Based on groundwater-sampling results documenting declining $\mathrm{COC}$ trends in the source area, stagnant plume with rate-limited release of residual contaminants, and low environmental risks, NDDH approved site abandonment and termination of corrective action. 


\section{JV TASK 59 - DEMONSTRATION OF ACCELERATED IN SITU CONTAMINANT DEGRADATION BY VACUUM-ENHANCED NUTRIENT DISTRIBUTION}

\subsection{INTRODUCTION}

At the request of the North Dakota Department of Health (NDDH) and the North Dakota Petroleum Tank Release Compensation Fund (NDPTRCF), the Energy \& Environmental Research Center (EERC) conducted remediation of hydrocarbon-contaminated soils and groundwater at a former Mohler Oil site in Bismarck, North Dakota.

The overall objective of the project activities was to design, implement, and operate a vacuum-enhanced recovery/multiphase extraction (MPE) system combined with nutrient injection to reduce contaminant concentration levels in soils and groundwater at the subject site to levels that would allow for natural attenuation processes to complete in situ degradation of residual contaminants.

Characteristics of the target zone, site urban location, and high traffic required the application of highly flexible remediation technology capable of simultaneously removing contaminants in both the vapor and liquid phases. MPE combined with nutrient injection using specifically designed mobile extraction and injection systems was recommended as the technically most feasible option capable of achieving high contaminant removal rates while controlling the contaminant migration off-site. The project was initiated in March 2003. The MPE system operated between June and September 2003 and 2004. In addition to contaminants of concern (COC) recovery, simultaneous nutrient injection and plume interception in the permeable treatment barrier were conducted each spring/summer season from 2003 to 2006 to accelerate the in situ biodegradation process.

This report presents a summary of results including a description of the technology applied. More detailed information, original data sets, and primary documentation are compiled in technical progress reports provided to the sponsors and regulatory agency on a quarterly basis. The project was sponsored by NDPTRCF and the U.S. Department of Energy (DOE) and supervised by NDDH.

\subsection{EXPERIMENTAL}

The remedial strategy at the subject site was based on application of two innovative concepts: 1) design and deployment of the mobile extraction, treatment, and injection units to overcome site limitations associated with urban setting in high traffic areas, and 2) vacuumcontrolled nutrient injection within and on the periphery of a vacuum-induced hydraulic and pneumatic depression.

Definition of the contaminated target zone, contaminant properties, and the results of the EERC pilot test indicated that remediation technology or a combination of technologies suitable for the subject site must be capable of:

- Efficiently removing contaminants from both the vadose and saturated zones in tight heterogeneous sediments with extremely low permeability. 
- Creating a hydraulic impact that would allow for contaminant recovery from inaccessible plume areas and reduce/control free product (FP) and contaminant migration off-site.

- Being flexible enough to address water table fluctuation across the contaminant smear zone.

- Providing for accelerated nutrient supply to stimulate biodegradation.

- Providing nutrient supply to the permeable treatment barrier intercepting the plume to stimulate in situ contaminant degradation processes.

Additional objectives and requirements for this demonstration were:

- A flexible design and operation of mobile extraction and injection systems to overcome site limitations associated with an urban setting in high-traffic areas.

- Well field design that would not be disruptive to traffic and daily operation of facilities at the site.

\subsection{RESULTS AND DOCUMENTATION}

\subsection{Site Characteristics}

\subsubsection{Site Location and Contaminant Release History}

The original source area at Mohler Oil Company, Inc. (J\&D Service Station), currently Mr. Muffler and Mr. Tire Services, 704 East Bowen Avenue, T138N R80W Section 4, Burleigh County, Bismarck, North Dakota, is approximately $100 \times 100 \mathrm{ft}$. The documented extent of the contaminant plume is at approximately $400 \times 300 \mathrm{ft}$ and covers all corners of the intersection between 7th Street and Bowen Avenue. The site layout including the inferred contaminant plume is provided in Figure 1 and Appendix A.

A line leak of unknown volume discovered in April 1990 was reported to NDDH on March 18, 1992. Actions taken prior to initiation of the EERC corrective action included environmental site assessment (ESA) Phases I and II conducted by Braun Intertec, Inc., in 1992, 1993, and 1995 [1-3] and groundwater monitoring and product absorbent installation by Water Supply, Inc., in 2002 [4]. A pilot test and feasibility study for vacuum-enhanced nutrient injection were conducted by the EERC in 2002 [5]. 


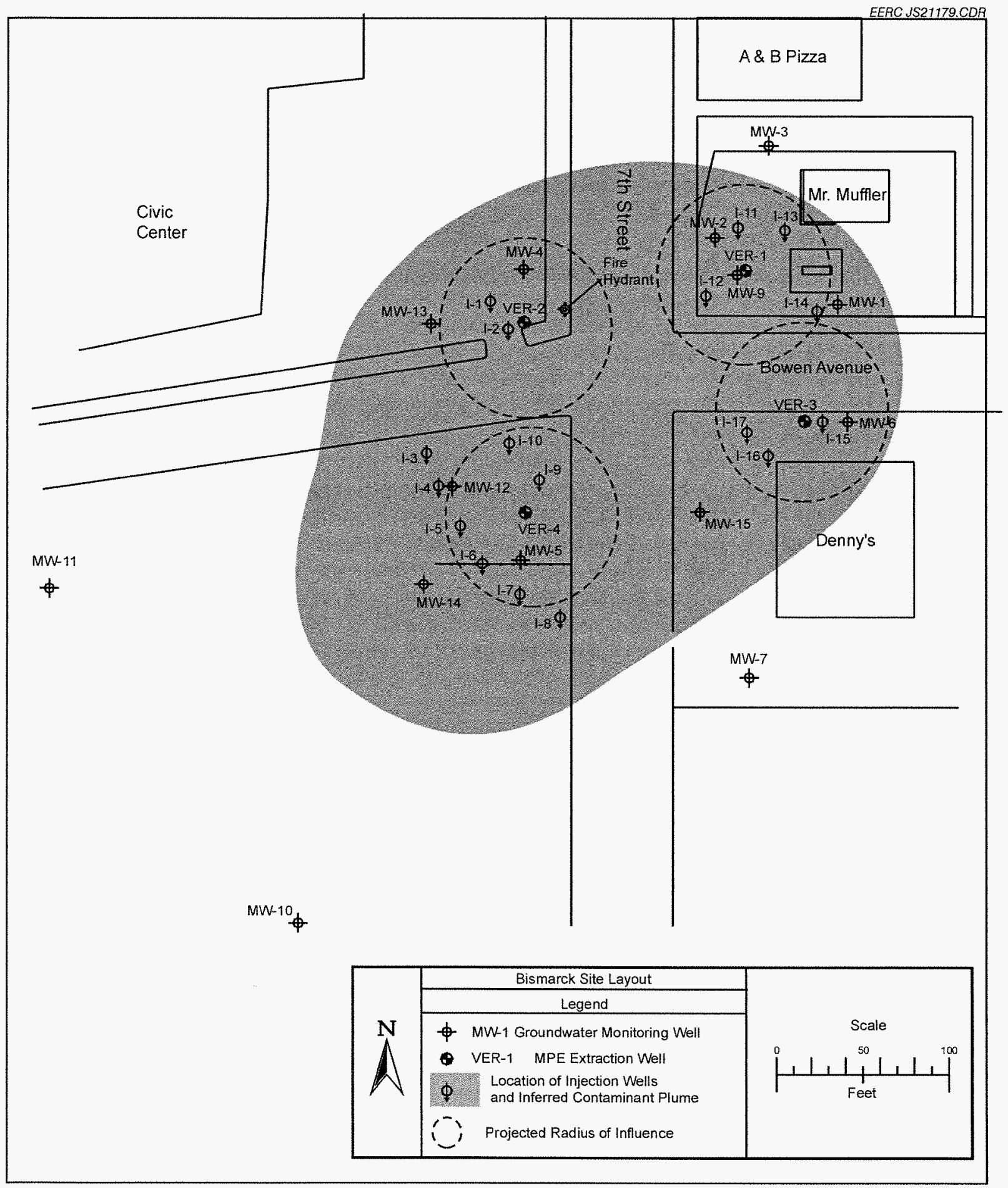

Figure 1. Site plan. 


\subsubsection{Hydrogeology and Contaminant Transport}

The geology of the impacted area is dominated by a heterogeneous complex of clays, silts, and silty sands developed in the depositional environment on the margin of the alluvial plain and upper terrace. The sediment profile consists of up to 12 feet of fill material in the source (original contaminant release) area, underlain by 10-15-ft-thick till dominated by silty clays interbedded with thin layers of sandy silts. Till is underlain by a layer of poorly sorted fine to medium silty sand at a depth of about $25 \mathrm{ft}$.

The groundwater flow and downgradient contaminant migration is bound to discrete silty and sandy layers interbedding mostly clayey silts and silty clays that dominate the geology of the target area. The unconfined water table ranged from 13.28 to $22.51 \mathrm{ft}$ below ground. The relatively abrupt gradient change on the margin of the terrace and alluvial plain may provide for partial groundwater confinement in the downgradient section of the impacted area. Water-table fluctuation during the project was about $4.7 \mathrm{ft}$, with the highest levels recorded in June 2003 and the lowest in November 2006. A summary of semiannual groundwater-monitoring data, including a water-table map, is in Appendix B.

Reflecting on-site geology, the hydraulic parameters exhibit considerable horizontal and vertical variability across the impacted area. In spite of low hydraulic conductivity for most of the sediments, contamination was detected in MW-5 (over $200 \mathrm{ft}$ downgradient from the source) as early as 2 years after leak detection. Although previous undetected contaminant release cannot be ruled out, deduced transport velocity of about $100 \mathrm{ft} /$ year is higher than that derived from results of hydraulic testing. Contamination as far as $300 \mathrm{ft}$ from the source was confirmed in soil samples. The layers of preferential flow that allow for transport of free- and dissolved-phase contaminants off the site could have hydraulic conductivity several orders of magnitude higher than ambient till. Groundwater table fluctuation is an additional factor contributing to contaminant distribution, allowing for faster migration when the product-water interface is in more permeable materials. This factor is even more pronounced under semiconfining conditions or if the water level is as low as the sandy layer underlying the impacted area.

\subsection{Remediation Systems}

\subsubsection{Extraction, Monitoring, and Injection Well Fields}

The extraction, injection, and monitoring well fields for full-scale contaminant extraction and nutrient injection consist of four (4) extraction wells, 17 injection wells, and 14 monitoring wells. Well fields were completed May 27 - June 1, 2003. Existing wells including wells completed for the EERC pilot test [1] were integrated into the final extraction and monitoring well field (Figure 1 and Appendix A). Based on hydraulic and pneumatic response during MPE and hydraulic testing conducted in October 2002, the projected radius of influence for extraction wells was 35-50 ft. Injection wells are located on the periphery or within the projected radius of influence to allow for enhanced nutrient distribution in response to vacuum-induced depression. Wells forming a permeable treatment zone in the southwest portion of the plume are spaced approximately $20 \mathrm{ft}$ apart to intercept groundwater flow and downgradient spreading of the contaminant plume (Figure 1).

Extraction well boreholes were advanced by a 6-in.-i.d. (10-in.-o.d.) hollow-stem (HS) auger. Wells were completed with 4-in.-diameter flush-threaded PVC, Schedule 40, with a 0.020 -in. slot screen and No. 30 red flint pack. Extraction wells were sealed and equipped with a 1-in. PVC suction tube extending 4-6 ft below the water table (at the time of operation). 
Monitoring wells were advanced using 4-in.-i.d. by 8-in.-o.d. hollowstem auger and completed as 2 in.-diameter flush-threaded PVC, Schedule 40 groundwater-monitoring wells. All extraction monitoring wells were further equipped with pressure- and water-table-monitoring ports with a $3 / 4$-in. drop tube extending to $<1 \mathrm{ft}$ from the bottom of the well.

Injection wells were advanced using the same drilling technology and completed with 2-in.-diameter flush-threaded PVC, Schedule 40, with a 10-15 ft of 0.020-in. slot screen. In the absence of well-defined permeable preferential pathways in tight geology, this drilling and well completion design was preferred to direct push injection points. Using the same gravel pack material, this injection well construction provides about a 6.7 times (85\%) larger contact area per unit length and over 44 times (98\%) larger storage volume above the water table (20 ft) than a 1.5-in.-diameter direct push injection point.

Well completion data including geologic and survey logs are provided in the Technical Progress Report for April-June 2003 [6]. Following NDDH and EERC agreement on final activities at the site from November 28, 2006, five monitoring wells, namely MW-2, MW-9, MW13, MW-14, and MW-15, were preserved for monitoring of site conditions and natural attenuation parameters. The remaining extraction, injection, and monitoring wells including piping and manifolds in the ground will be sealed in compliance with North Dakota Administrative Code Article 33-18 and NDDH guidelines for well abandonment in April 2007.

\subsubsection{Multiphase Extraction and Treatment System}

In order to overcome site limitations associated with its urban location and high-traffic areas, the EERC team in cooperation with Specialty Systems Integrators, Inc., designed and constructed trailer-mounted extraction and injection systems powered by an auxiliary generator.

The mobile MPE system consists of a CoVac-300 4-stage, 15-hp, oil-free regenerative blower with a maximum rating of $205 \mathrm{cfm}$ and 24.5-in. $\mathrm{Hg}$ (135 cfm @ 24.5-in. Hg). Recovered water and air pass through the 60-gal vapor-liquid separator (VLS) to the oil-water separator (OWS) with a 60-gal product storage tank. Water from OWS overflows to a 60-gal equalization tank, is charged in a Freije Series $S$ treatment unit, and then pumped to a 5-stage air stripper (AS). Water from the AS is filtered and treated by GAC (granular activated carbon) prior to discharge. Offgas was treated in two vessels in series with $1000 \mathrm{lb}$ of vapor carbon each prior to discharge to the atmosphere during the first month before representative offgas analyses became available. A process and instrumentation diagram for the extraction system is provided in Appendix C.

The extraction and treatment system is equipped with a NEMA 4 electric controller and a programmable logic controller (PLC) allowing for system control and data acquisition. The entire system is mounted on a $6-\times 15-\mathrm{ft}$ trailer platform. Basic operational parameters are summarized in Table 1.

\subsubsection{System Performance Monitoring and Sampling}

The operation of the MPE and treatment system started on June 11,2003. Operation of the injection system started on June 18, 2003, after a sufficient hydraulic and pneumatic depression was developed around the extraction well. Performance monitoring, effluent water, and offgas sampling, including sampling of nutrient concentrations in the injected mixture were conducted on a weekly basis. The relocation of remediation systems was performed after COC 
trends in recovered groundwater and offgas exhibited asymptotic trends for a given extraction field.

Table 1. Operational Parameters

\begin{tabular}{lcccc}
\hline Extraction Well & VER-1 & VER-2 & VER-3 & VER-4 \\
\hline Operated (2003) & $6 / 10-8 / 5$ & $10 / 15-11 / 1$ & $8 / 5-9 / 3$ & $9 / 4-10 / 15$ \\
Operated (2004) & $7 / 14-8 / 31$ & $6 / 1-7 / 8$ & - & $9 / 14-10 / 7$ \\
Inlet Vacuum (in. Hg) & $18.5-22.5$ & $16-18$ & $18.5-23$ & $17-22$ \\
Wellhead Vacuum (in. $\mathrm{H}_{2} \mathrm{O}$ ) & $87.3-104.9$ & $165-170$ & $\mathrm{NR}^{1}$ & $141.3-144.2$ \\
Groundwater Flow (gpm) & $0.4-2.2$ & $0.9-2.4$ & $0.1-0.6$ & $3.1-3.6$ \\
Groundwater Recovered (gal) & 167,356 & 101,837 & 118,417 & 111,626 \\
Airflow (scfm) & $37.4-48$ & $32.7-39.1$ & $24.2-41.3$ & $21.1-42.9$ \\
Actual Time (day) & 104 & 53 & 52 & 41 \\
Runtime (h) & 2420 & 807 & 915 & 542 \\
Downtime (h) & 90 & 463 & 324 & 441 \\
\hline
\end{tabular}

${ }^{1}$ Not representative - wellhead dilution required.

\subsubsection{System Water Quality}

Samples of extracted water and treated effluent were analyzed for COC (benzene, toluene, ethylbenzene, xylenes, phenols, and total petroleum hydrocarbons [TPH] as gasoline range organics [GRO]), total iron and manganese, and suspended solids. Field measured parameters included $\mathrm{pH}$, electrical conductivity $(\mathrm{EC})$, and temperature.

Values representing contaminant recovery confirmed declining trends in the source area with a 95\% GRO and BTEX decline in groundwater recovered between June 2003 and August 2004 (Figure 2). Contrary to the source area, relatively stable or even increasing COC concentrations were documented downgradient from the source (Figure 3 ) in response to vacuum-induced flow (and recovery) of residual contaminant in sediments underlying the intersection of Bowen Avenue and 7th Street. A summary of extraction and treatment data is provided in Appendix E-1; complete analytical documentation is in the respective technical progress reports. A $100 \%$ water treatment system efficiency was achieved for BTEX removal.

\subsubsection{Offgas Quality}

Offgas quality from combined exhaust was monitored using charcoal tubes and real-time monitoring of hydrocarbons, $\mathrm{CO}_{2}$, and $\mathrm{O}_{2}$ using a photoionization detector (PID), a flame ionization detector (FID), and a Summit hydrocarbon analyzer.

Offgas-sampling results using charcoal tube desorption and analyzed by gas chromatography (GC)/FID are summarized in Appendix E-2. Volatile organic contaminants (VOC) concentration trends from the 2003 extraction trial are provided in Figure 4. To overcome fluctuating airflow velocities typical of MPE systems, offgas was collected in a 1-I Tedlar bag at a rate of approximately $0.3 \mathrm{l} / \mathrm{min}$. Charcoal tube samples were subsequently collected directly from the Tedlar bag using an SKC pump with flow regulated at $0.28 \mathrm{l} / \mathrm{min}$. In addition, carbon dioxide and oxygen trends in extracted vapors were monitored using the Summit analyzer. The 


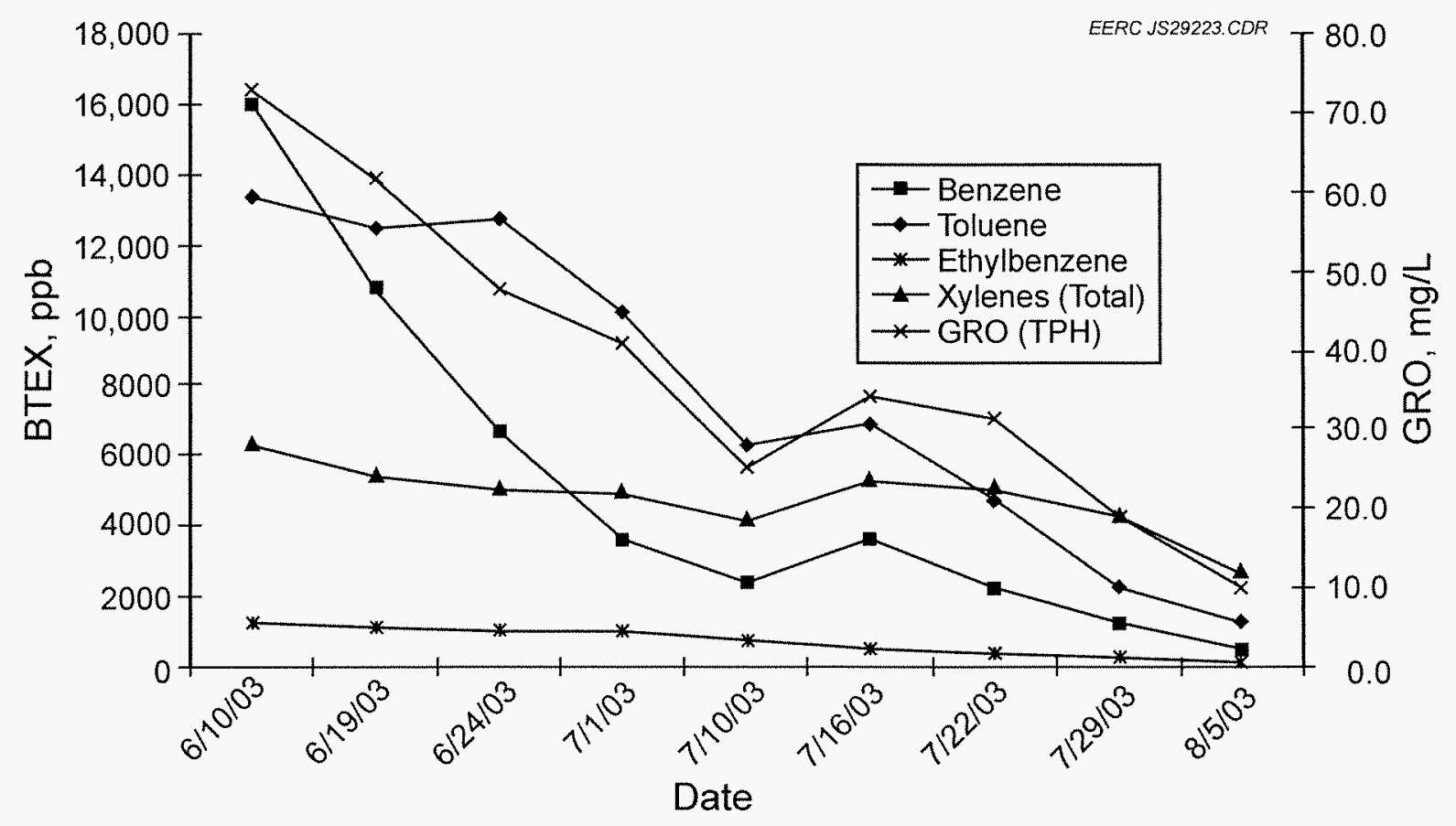

Figure 2. COC trends in extracted groundwater - source area (data from 2003).

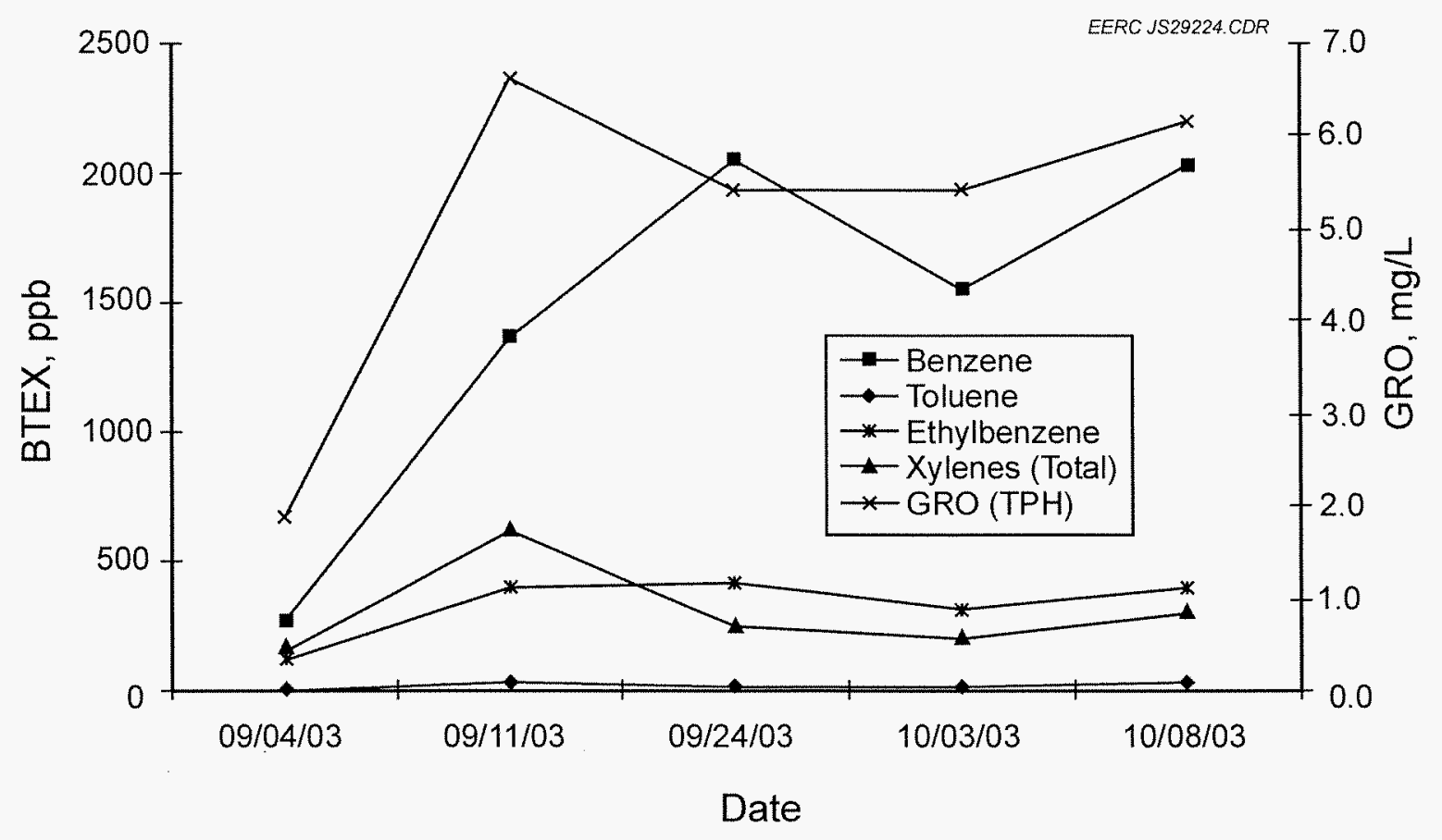

Figure 3. COC trends in extracted groundwater - downgradient area (data from 2003). 


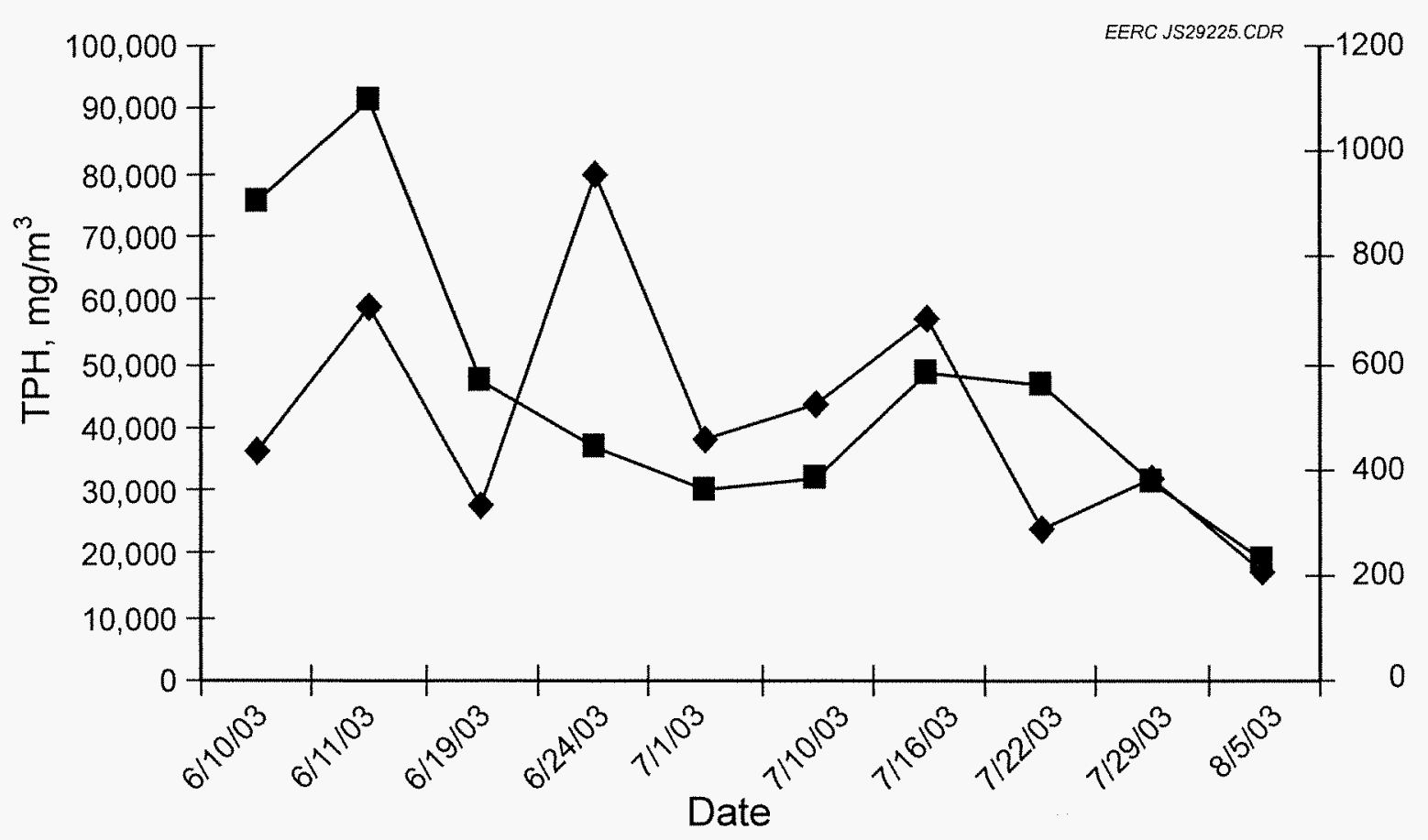

Figure 4. Hydrocarbon concentration trends in offgas - source area 2003.

mass balance for recovered VOCs and average emission loads was calculated based on results of offgas analyses and average exhaust airflow corrected to standard conditions and reported to $\mathrm{NDDH}$ on a quarterly basis.

Extremely high VOC concentrations peaked at $146,000 \mathrm{mg} / \mathrm{m}^{3}$ (TPH) and $12,990 \mathrm{mg} / \mathrm{m}^{3}$ for BTEX during the first days of extraction and indicated the presence of considerable amounts of residual FP trapped within the vadose and dewatered smear zone (Appendix E-2). VOCs in offgas typically sharply declined within several weeks of operation of a new well field and were below the NDDH required limit for VOCs of $16 \mathrm{lb} / \mathrm{hr}$.

\subsubsection{Hydraulic and Pneumatic Response}

Groundwater table monitoring at the extraction and monitoring wells was conducted on a weekly basis during operation of remediation systems. In spite of tight site geology, pneumatic and hydraulic response in the source area was confirmed at monitoring wells as far as $58 \mathrm{ft}$. Hydraulic data indicate relatively slow response to induced gradient change, representative of tight sediments.

\subsubsection{Injection System}

The injection system consists of a 375-gal equalization tank allowing for continuous or batch injection feed. Water from the equalization tank is enriched with nutrients using an automatic chemical/nutrient feed pump and oxygen from a generator using pressure swing adsorption via molecular sieves to deliver oxygen into the water stream. Nutrient and oxygenenriched water passes through a high-pressure gas liquid contactor (GLC) prior to its diversion into individual injection links. The entire system including its electronic process controllers is 
mounted on an enclosed trailer. A process and instrumentation diagram for the injection system is provided in Appendix $\mathrm{C}$.

\subsubsection{Injection System Performance Monitoring}

Operation of the injection system in 2003 followed the relocation pattern of the MPE system, starting in the source area after a sufficient hydraulic and pneumatic depression was developed around extraction well VER-1. Formation capability to accept and conduct injected water between injection and extraction wells exceeded original expectations based on hydraulic testing. Nitrogen concentrations in injected water and groundwater extracted from well VER-1 indicate that nitrate breakthrough or recirculation of injected water occurred within the first days of injection (Appendix D-3). After MPE recovery from the first location reached asymptotic trends, the entire combined operation was relocated to the south (VER-3), southwestern (VER4 ), and northwestern (VER-2) corner of the plume (Figure 1). Injection system operation in 2004-2006 focused on nutrient delivery in the southwestern portion of the plume, creating a permeable treatment barrier consisting of injection wells I-3, 4, 5, 6, 7, 8, 9, and 10 and VER-4.

City water enriched with oxygen $\left(20-44 \mathrm{mg} / / \mathrm{O}_{2}\right)$ and nitrogen in the form of a mixture of liquid fertilizers UAN 28-0-0 (urea ammonium nitrate) and 10-34-0 (polyphosphate and ammonia nitrogen) was injected into injection wells. The average nitrogen concentration in injected water ranged from 20 to $38.8 \mathrm{mg} / \mathrm{l}$ (Appendix D-3). Background concentrations of nitrogen in groundwater upgradient from the contaminant plume documented from unimpacted well MW-3 ranged between 62 and $78 \mathrm{mg} / \mathrm{l}$ during the project. Nitrogen concentrations in most wells within the impacted area were below detection limits. Similarly, the results from injection wells forming a permeable barrier sampled in October 2004, May 2005, and October 2006 (after four injection seasons were completed) document fast nitrogen consumption, indicating both a severe deficit of electron acceptors within the plume and active biodegradation.

Over 1.7 million gallons $\left(6.7 \mathrm{~m}^{3}\right)$ of $\mathrm{O}_{2}$-oversaturated and nutrient-enriched water was injected between June 2003 and September 2006. A total of $1504 \mathrm{lb}(682 \mathrm{~kg})$ of ionic nitrate (338 lb-153.4 kg nitrogen) and $540 \mathrm{lb}(245 \mathrm{~kg}$ ) of oxygen was delivered to the contaminated aquifer to stimulate in situ biodegradation processes. A summary of injected volumes is provided in Table 2, mass balance estimates for primary electron acceptors (oxygen and nitrate) are presented in Appendix D-3.

Table 2. Injection Mass Summary

\begin{tabular}{|c|c|c|c|c|c|}
\hline \multirow[b]{2}{*}{ Season } & \multicolumn{2}{|c|}{ Date } & \multirow{2}{*}{$\begin{array}{l}\text { Water Injected } \\
\text { (gal) }\end{array}$} & \multirow{2}{*}{$\begin{array}{c}\mathrm{N} \\
(\mathrm{kg})\end{array}$} & \multirow{2}{*}{$\begin{array}{c}\mathrm{O}_{2} \\
(\mathrm{~kg})\end{array}$} \\
\hline & Start & End & & & \\
\hline 2003 & $06 / 16 / 03$ & $11 / 03 / 03$ & 554,985 & 28.9 & 92.9 \\
\hline 2004 & $06 / 08 / 04$ & $10 / 07 / 04$ & 546,261 & 41.7 & 65.0 \\
\hline 2005 & $06 / 22 / 05$ & $09 / 13 / 05$ & 382,850 & 53.1 & 45.0 \\
\hline 2006 & $06 / 12 / 06$ & 09/06/06 & 282,788 & 29.7 & 41.7 \\
\hline Total & & & $1,766,884$ & 153.4 & 244.6 \\
\hline
\end{tabular}

\subsection{Contaminant Recovery and Degradation Estimates}

The contaminant mass removal estimates were determined using the volumes for extracted groundwater and vapor and average VOC concentration obtained during two 
consecutive sampling events. A total of 499,119 gallons $\left(1,889 \mathrm{~m}^{3}\right)$ of groundwater and 11 million $\mathrm{ft}^{3}\left(-313,000 \mathrm{~m}^{3}\right)$ of soil vapor was extracted from recovery wells during two extraction seasons, resulting in removal of $13,630 \mathrm{lb}(6,183 \mathrm{~kg})$ of hydrocarbons prior to stripping and an additional $66.5 \mathrm{lb}(30 \mathrm{~kg})$ from the treated groundwater. The average liquid flow rate was approximately $2.1 \mathrm{gpm}$, ranging from 0.9 to $5.5 \mathrm{gpm}$, depending on performance of individual wells (Table 1); the airflow rate ranged from 21.1 to $60.2 \mathrm{scfm}$. The mass of recovered contaminant is equivalent to approximately 2176 gallons $(8,236 \mathrm{l})$ of product, assuming a specific gravity for gasoline of $0.75 \mathrm{~g} / \mathrm{cm}^{3}$.

Total summary of contaminant recovery is in Table 3; data for mass removal calculations are provided in Appendix D; cumulative recovery is presented in Figure 5.

Table 3. MPE System Contaminant Recovery

\begin{tabular}{lccc}
\hline Phase & 2004 & 2003 & \\
\hline Vapor (lb) & 4325 & 9306 & \\
Liquid (lb) & 21 & 45.5 & \\
\hline Total (lb) & 4346 & 9351.5 & 13,698 \\
\hline
\end{tabular}

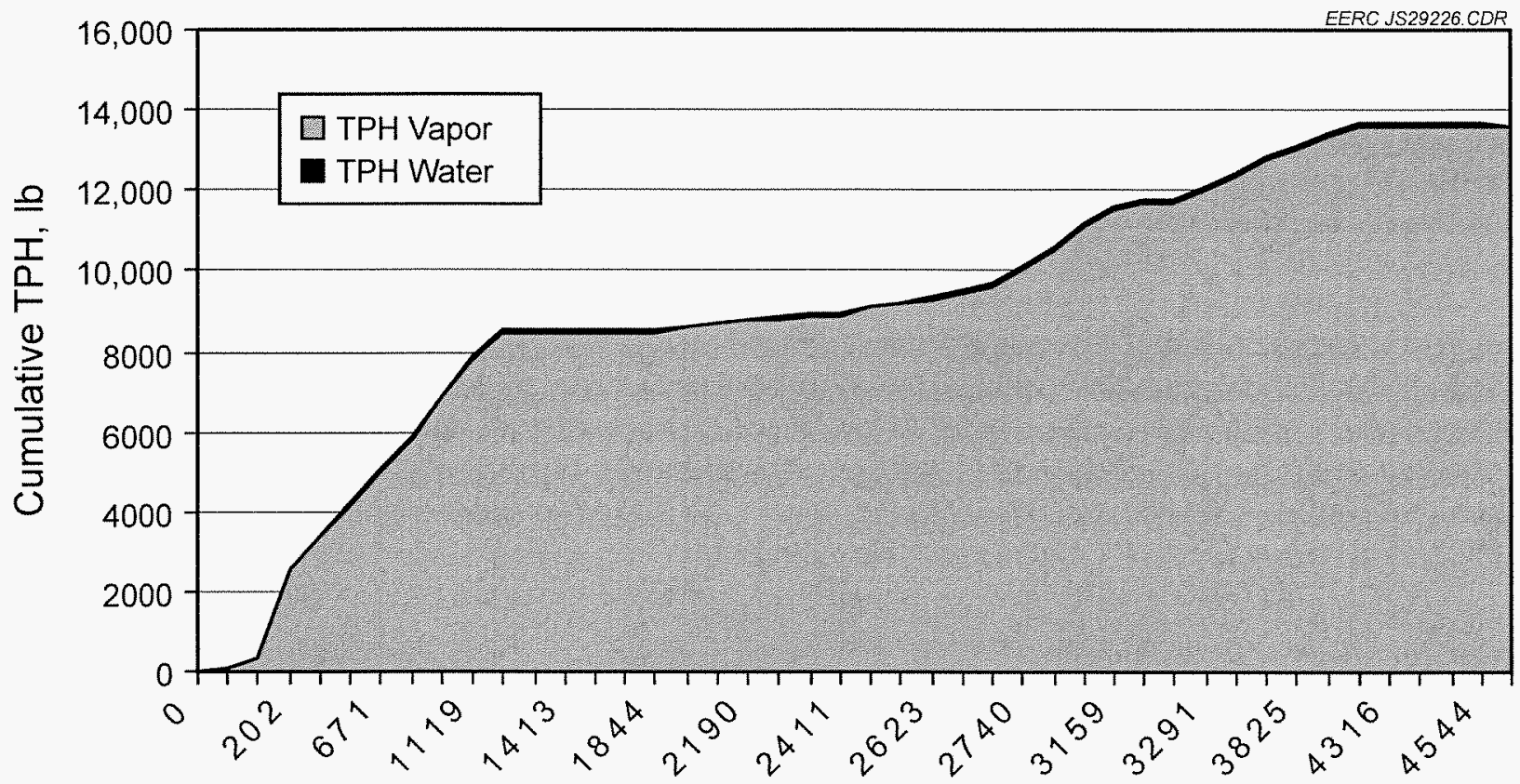

Run Time since Start-Up, hours

Figure 5. Total hydrocarbon removal.

Over 1.7 million gallons $\left(6.7 \mathrm{~m}^{3}\right)$ of $\mathrm{O}_{2}$-oversaturated and nutrient-enriched water was injected, delivering $1504 \mathrm{lb}(682 \mathrm{~kg})$ of ionic nitrate and $540 \mathrm{lb}(245 \mathrm{~kg})$ of dissolved oxygen to the contaminated aquifer. Based on simplified stochiometry for electron donors (petroleum hydrocarbons) and electron acceptors, a reduction of $1 \mathrm{mg} / \mathrm{l}$ of dissolved oxygen consumed by microbes results in biodegradation of $0.32 \mathrm{mg} / \mathrm{l}$ of benzene, and each $1 \mathrm{mg} / \mathrm{l}$ of ionic nitrate contributes to biodegradation of $0.21 \mathrm{mg} / \mathrm{l}$ of benzene. Injected volumes for oxygen and nitrate 
translate into in situ reduction of $489 \mathrm{lb}(222 \mathrm{~kg})$ of benzene and provide for long-term stimulation of the natural attenuation process. A summary of injected volumes is provided in Table 2, mass balance estimates for primary electron acceptors (oxygen and nitrate) are presented in Appendix D-3.

In addition to contaminant recovered by extraction and reduced by in situ biodegradation as a result of nutrient injection, a total of $4136 \mathrm{lb}(1876 \mathrm{~kg})$ of oxygen was delivered to the saturated zone during operation of the MPE system in 2003 and 2004, assuming $2 \%$ oxygen transfer efficiency [7] and 11 million $\mathrm{ft}^{3}\left(313\right.$ thousand $\mathrm{m}^{3}$ ) soil vapor exchanged/recovered. By providing the necessary electron acceptor and using the same stoichiometry as for injection estimates, this volume translates into further in situ reduction of $1324 \mathrm{lb}(600 \mathrm{~kg})$ of contaminant. Contaminant recovery/degradation breakdown is provided in Table 4 . It is apparent that MPE technology using air as the primary contaminant carrier by far exceeds COC recovery and degradation efficiency of conventional pump-and-treat or in situ degradation based only on nutrient injection.

Table 4. Contaminant Recovery/Degradation Breakdown Estimates

\begin{tabular}{lrrrr}
\hline COC Recovered/Degraded & (lb) & \multicolumn{1}{c}{ Total } & \multicolumn{1}{c}{ (gal) } & \multicolumn{1}{c}{ (\%) } \\
\hline Vapor Extraction & 13631 & 6183 & 2178 & 87.9 \\
Water Extraction & 66.5 & 30 & 11 & 0.4 \\
Nutrient Injection $\left(\mathrm{NO}_{3}\right.$, Dissolved $\left.\mathrm{O}_{2}\right)$ & 489 & 222 & 78 & 3.2 \\
Degradation by Air Exchange/ $\mathrm{O}_{2}$ Delivery & 1324 & 601 & 212 & 8.5 \\
\hline Total & 15,111 & 7036 & 2478 & 100.0 \\
\hline
\end{tabular}

\subsection{Groundwater Quality Monitoring}

\subsubsection{Sampling Program}

Monitoring and extraction wells were sampled for BTEX, GRO, and biodegradation indicators on a semiannual basis to document overall remediation system impact on groundwater quality compared to original site data collected in June 2003 (prior to system startup). The final sampling was conducted on November 10-11, 2006.

Groundwater samples were collected using disposable PVC bailers, preserved on-site, and stored on ice prior to and during shipment. Samples for dissolved metals were filtered using $0.45-\mu \mathrm{m}$ Geotech disposable filters. Analyses were conducted by MVTL in Bismarck, North Dakota, and New UIm, Minnesota. Quality assurance/quality control samples included duplicates, equipment blanks, field blanks, and trip blanks for each sampling event. Fieldmonitored water quality parameters were measured in wells with an YSI-556 multiprobe.

\subsubsection{Water Quality Trends}

Consistently declining trends and $50 \%$ average COC reduction are documented from wells in the source area, namely VER-1, MW-1, MW-2, and MW-9. FP thickness downgradient from the source area was reduced in well MW-5 (sheen) but remains variable in wells MW-4 $(1.8 \mathrm{ft})$ and VER-2 (1 ft, Civic Center corner) and in hydraulically isolated MW-6 (2.42 ft). COC concentrations around VER-2 and VER-4 indicate that formation of a hydraulic depression 
around extraction wells in response to MPE accelerated the flow (and recovery) of residual contaminant in sediments underlying the intersection of Bowen Avenue and 7th Street. Observed COC trends for wells downgradient from the source area suggest that the majority of contaminant is trapped within the smear zone underlying the noted intersection, and any downgradient migration is limited by extremely low hydraulic conductivity and limited hydraulic connectivity of potential preferential pathways in silty clays.

A contaminant isoconcentration map for BTEX indicating the geometry of the contaminant plume as of October 9,2006, is presented in Appendix F; a summary of groundwater analyses is in Appendix G-1.

With respect to prevailing groundwater flow direction (Appendix B), location of the abandoned landfill, and occurrence of contaminated soils discovered during construction of the Civic Center, the origin of contamination in this area is likely not related only to the source area and may suggest the presence of additional contaminant source(s).

Summary tables for biodegradation indicators are provided in Appendix G-2. Compared to unimpacted wells (outside of the plume), and in spite of an increased nitrogen load in the nutrient mixture injected, biodegradation indicators persistently exhibit trends typical for an anaerobic contaminant plume with suppressed oxygen, nitrate, phosphorus, and sulfate concentrations; elevated concentrations of organic carbon; and reduced forms of iron and manganese. Analyses from monitoring wells presented in Appendix G-2 indicate that oxygen, nitrogen (both in nitrate-nitrite and ammonia form), and sulfate, as primary (high energy) electron acceptors during biodegradation, are effectively consumed within the plume area. Nitrate levels remain above nondetect levels only in the background and a few injection wells and appear to be quickly consumed by indigenous bacteria within the plume. Under prevailing reducing conditions and excess carbon (contaminants) within the contaminant plume, the deficit of electron acceptors and imbalance between C-N-P considerably reduce biodegradation potential. Increased ammonia nitrogen (representing nitrate injected and reduced to ammonia $\mathrm{N}$ under anaerobic conditions) is documented from wells MW-1, 2, and 9 in the source area and well MW-4, MW-12, and I-8.

\subsection{Technical and Economic Summary and Discussion}

The remedial strategy was based on application of two innovative concepts: 1) design and deployment of the mobile extraction, treatment, and injection units to overcome site limitations associated with urban setting in high-traffic areas and 2) vacuum-controlled nutrient injection within and on the periphery of an induced hydraulic and pneumatic depression.

High contaminant removal efficiency of dual-phase (multiphase) extraction technology is a result of a combination of simultaneous extraction of water and vapor. It follows from contaminant recovery/degradation breakdown estimates (Table 4) that vapor extraction efficiency by far exceeds that for groundwater (in this case by a factor of 205) and, to a certain extent, draws a comparison between soil vapor extraction and pump-and-treat systems. Documented high contaminant recovery using vapor as a primary carrier could not, however, be achieved without simultaneous dewatering of the targeted smear zone.

An additional advantage of dual-phase extraction is air exchange/oxygen delivery to the contaminated zone during operation of the MPE system. Because quantification of in situ oxygen partitioning between soil- and groundwater-bound contaminants and their subsequent 
reduction is extremely difficult, this means of degradation, albeit substantial, is often not considered by the environmental industry in mass balance estimates.

Based on project cost and total contaminant recovery of $14,187 \mathrm{lb}$ per unit, the cost for contaminant recovery was $\$ 48.9 / \mathrm{lb}(\$ 107.70 / \mathrm{kg})$. If in situ degradation resulting from oxygen delivery is considered, the cost would be $\$ 44.70 / \mathrm{lb}(\$ 98.60 / \mathrm{kg})$ of contaminant recovered/degraded. The relatively high cost per unit of contaminant recovered/degraded reflects on the site location in a developed urban setting, the requirement for initial offgas treatment and a robust monitoring program, as well as site abandonment activities being integrated into the total project cost.

\subsection{CONCLUSIONS}

A total of 499,119 gallons $\left(1889 \mathrm{~m}^{3}\right)$ of groundwater and 11 million $\mathrm{ft}^{3}\left(\sim 313,000 \mathrm{~m}^{3}\right)$ of soil vapor were extracted from recovery wells during two extraction seasons, resulting in removal of $13,630 \mathrm{lb}(6183 \mathrm{~kg})$ of hydrocarbons prior to stripping and an additional $66.5 \mathrm{lb}$ $(30 \mathrm{~kg})$ from the treated groundwater. The mass of recovered contaminant is equivalent to 2176 gallons ( $8236 \mathrm{I}$ ) of product recovered at the site since the beginning of the project in June 2003.

In situ delivery of $1504 \mathrm{lb}(682 \mathrm{~kg})$ of ionic nitrate and $540 \mathrm{lb}(245 \mathrm{~kg})$ of dissolved oxygen conducted in 2003-2006, i.e., four injection seasons, translates into further reduction of about $489 \mathrm{lb}(222 \mathrm{~kg})$ of benzene for the same period and provides for long-term stimulation of the natural attenuation process.

In addition to contaminant recovered by extraction and reduced by in situ biodegradation as a result of direct nutrient injection, a total of $4136 \mathrm{lb}(1876 \mathrm{~kg})$ of oxygen was delivered to the saturated zone during operation of the MPE system in 2003 and 2004. By providing the necessary electron acceptor, this volume translates into further in situ reduction of an estimated $1324 \mathrm{lb}(600 \mathrm{~kg})$ of dissolved-phase hydrocarbons.

Based on groundwater-sampling results documenting declining COC trends in the source area, stagnant plume with rate-limited release of residual contaminant, and low environmental risks, NDDH approved termination of corrective action and initiation of site abandonment. Wells MW-2, $9,13,14$, and 15 will be preserved for postclosure site monitoring.

\subsection{REFERENCES}

1. Braun Intertec Environmental, Inc., July 1992, Report on preliminary subsurface assessment at former J\&D Service Station.

2. Braun Intertec Environmental, Inc., January 1993, Expanded subsurface assessment at former J\&D Service Station in Bismarck, North Dakota.

3. Braun Intertec Environmental, Inc., January 1995, Upgradient petroleum product release investigation for former J\&D Service Station.

4. Water Supply, Inc., January 2002, Monitoring at former J\&D Service Station. 
5. Solc, J., and Reilkoff, T.E., 2002, Mohler Oil - feasibility of remedial alternatives: EERC final report no. 2002-EERC-12-04.

6. Solc, J., and Reilkoff, T.E., 2003, Mohler Oil: EERC technical progress report for AprilJune 2003.

7. Kuo, J., 1999, Practical design calculations for groundwater and soil remediation: Boca Raton, Florida, CRC Press, LLC Lewis Publishers. 


\section{APPENDIX A}

SITE PLAN AND EXTRACTION/INJECTION WELL

FIELDS 


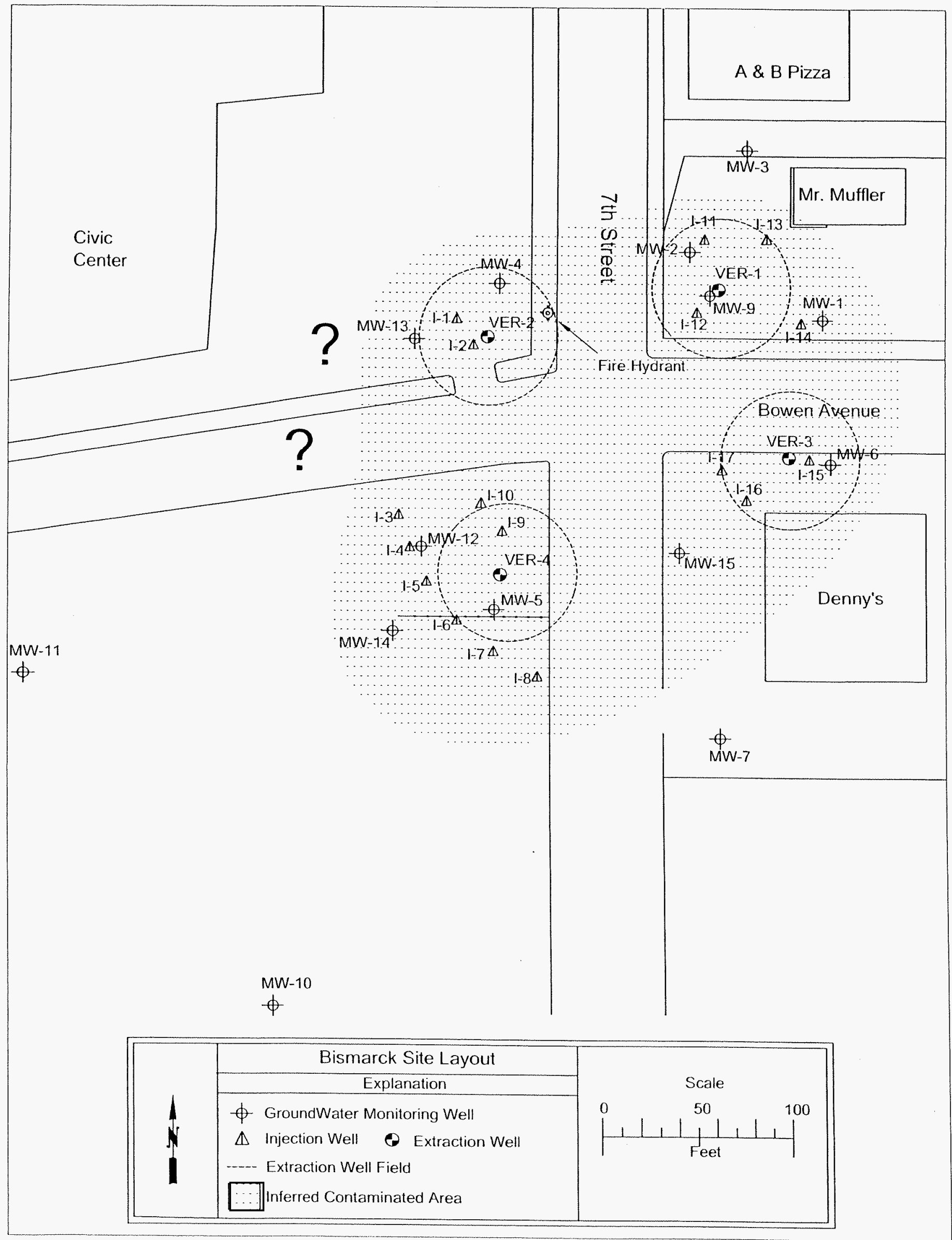


APPENDIX B

\section{GROUNDWATER TABLE MONITORING - SUMMARY OF DATA}




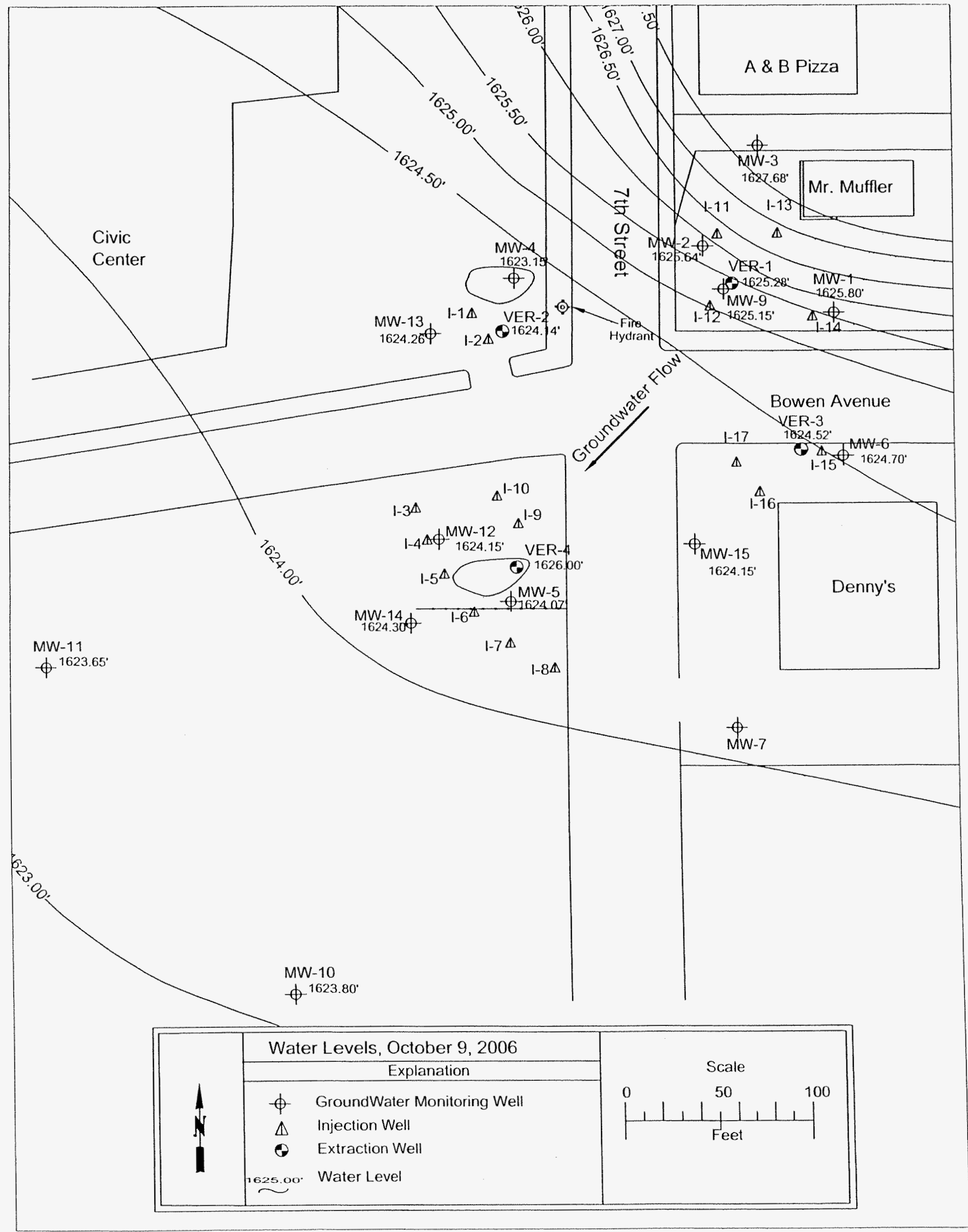




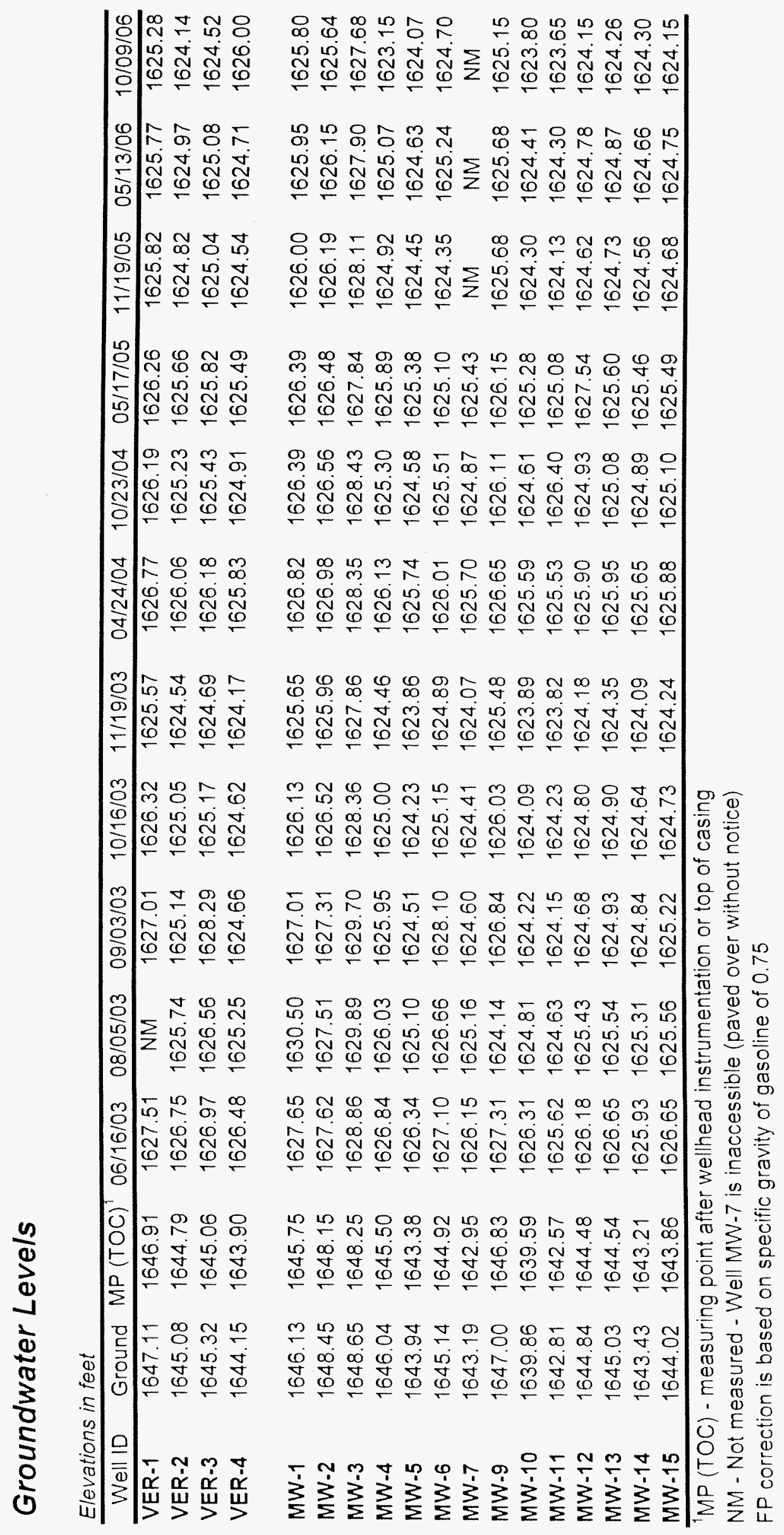


APPENDIX C

RECOVERY AND INJECTION SYSTEMS 


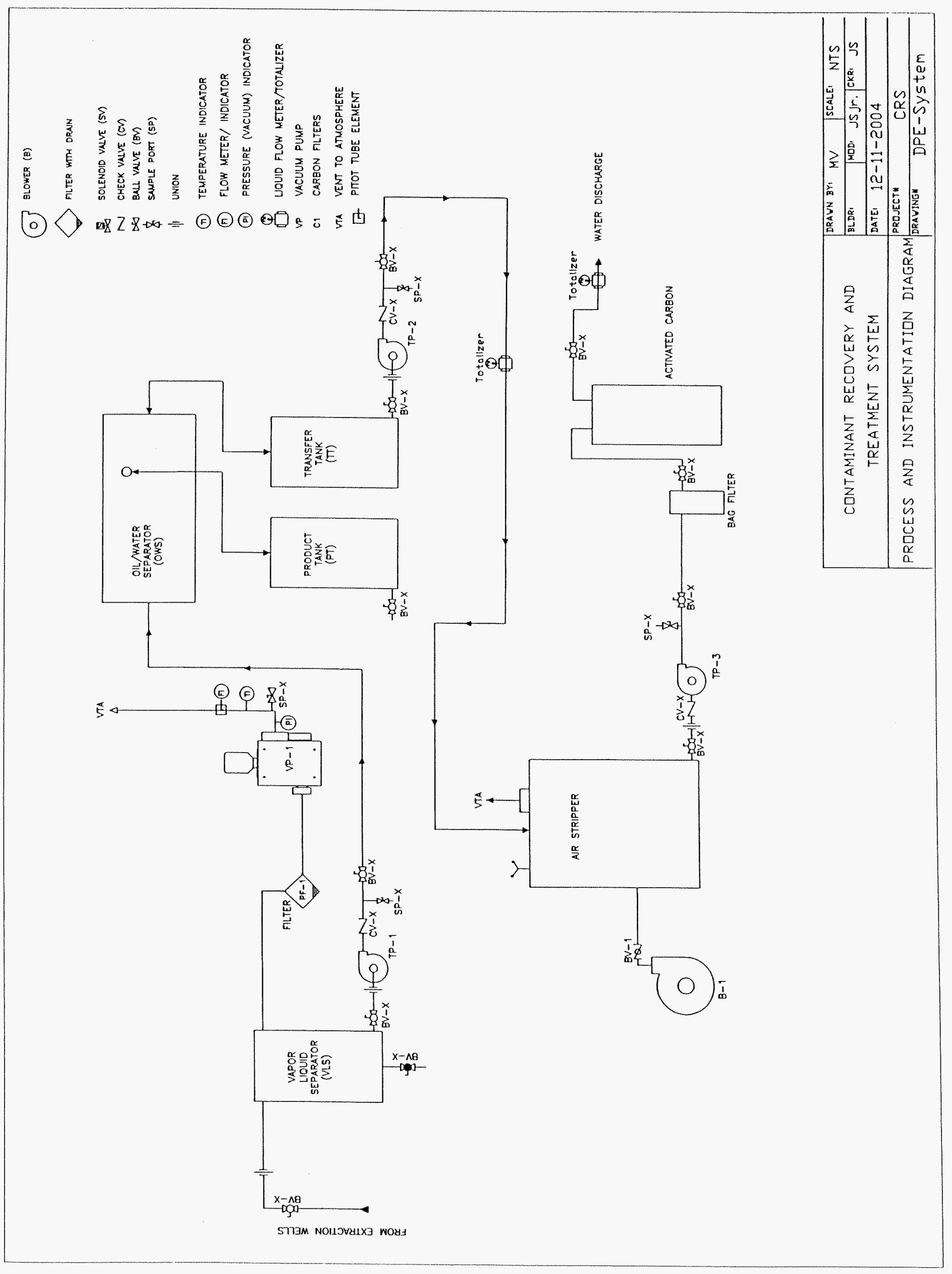



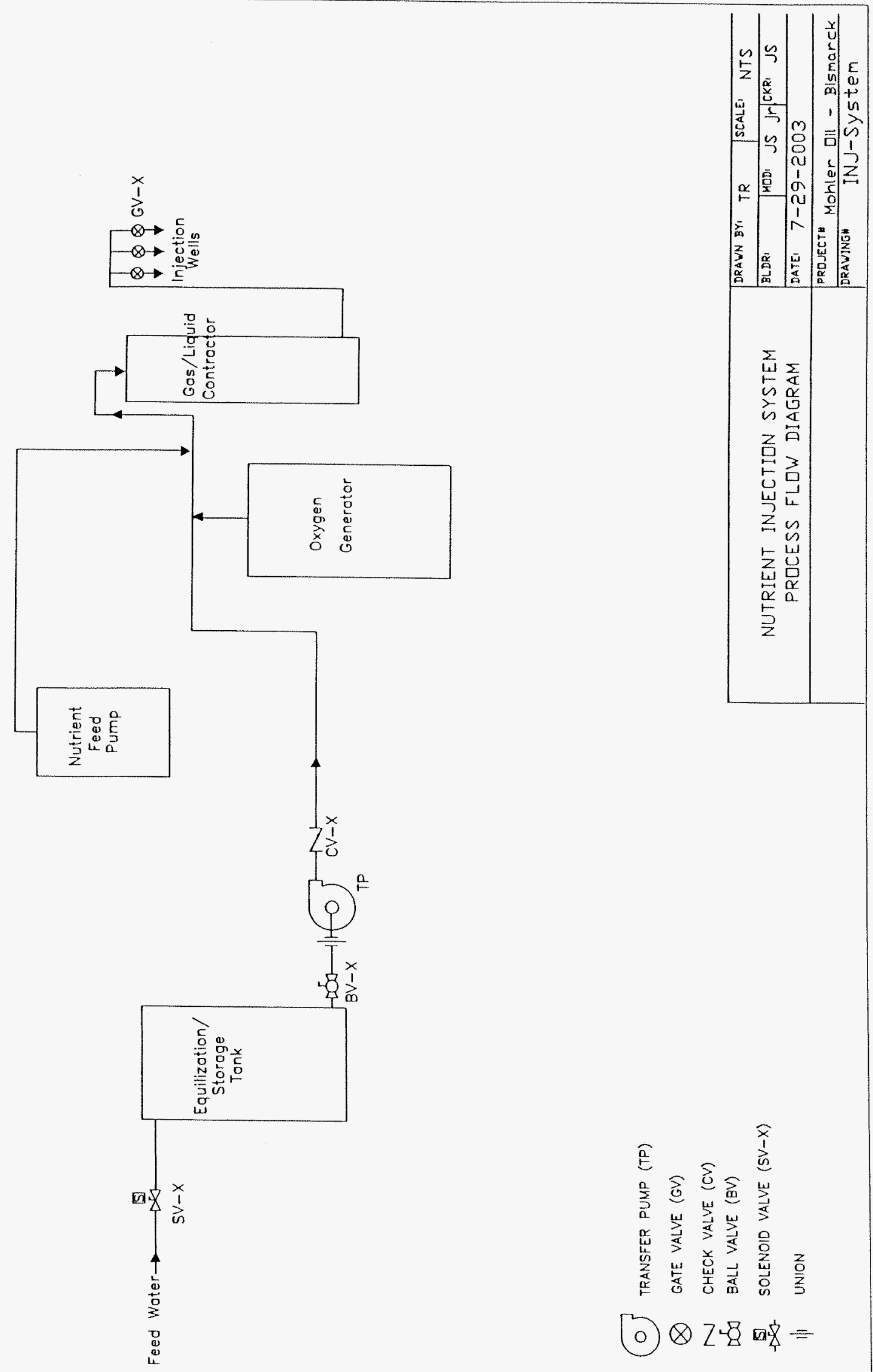

i.

$\stackrel{5}{\omega} \frac{\sum}{\alpha}$

玄皆

z台

点各

넌

는

出

뭉

$\frac{2}{5}$

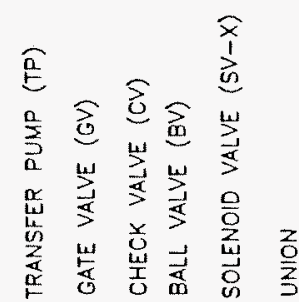

(0) 878 叫 $=$ 
APPENDIX D

\section{MASS BALANCE WORKSHEETS}




\section{APPENDIX D-1}

\section{CONTAMINANT RECOVERY - LIQUID PHASE}




\section{CONTAMINANT RECOVERY}

TPH - Liquid Phase 2003 Season

\begin{tabular}{|c|c|c|c|c|c|c|}
\hline Date & $\begin{array}{c}\text { Totalizer } \\
\text { (gal) }\end{array}$ & $\begin{array}{l}\text { Flow } \\
\text { (gpm) }\end{array}$ & $\begin{array}{c}\mathrm{TPH}_{\text {water }} \\
\mathrm{mg} / \mathrm{l}\end{array}$ & $\begin{array}{c}\text { BTEX }_{\text {water }} \\
\mathrm{mg} / \mathrm{l}\end{array}$ & $\begin{array}{c}\mathrm{TPH}_{\text {mass }} \\
\text { (Ib) }\end{array}$ & $\begin{array}{l}\text { BTEX }_{\text {mass }} \\
\text { (lb) }\end{array}$ \\
\hline \multicolumn{7}{|c|}{ Recovery Field VER-1 } \\
\hline $06 / 10 / 03$ & 1209 & 0.4 & 72.8 & 37.0 & 0.1 & 0.0 \\
\hline $06 / 11 / 03$ & 1987 & 0.8 & 52.5 & 24.6 & 0.4 & 0.2 \\
\hline 06/19/03 & 12325 & 1.0 & 61.4 & 29.7 & 4.9 & 2.3 \\
\hline $06 / 24 / 03$ & 25345 & 1.7 & 47.5 & 25.5 & 5.9 & 3.0 \\
\hline 07/01/03 & 44317 & 2.1 & 40.7 & 19.6 & 7.0 & 3.5 \\
\hline 07/10/03 & 69215 & 2.2 & 25.4 & 13.7 & 6.9 & 3.4 \\
\hline $07 / 16 / 03$ & 80510 & 1.3 & 34.1 & 16.5 & 2.8 & 1.4 \\
\hline $07 / 22 / 03$ & 85176 & 0.5 & 31.1 & 12.4 & 1.3 & 0.6 \\
\hline $07 / 29 / 03$ & 97011 & 1.2 & 19.3 & 8.1 & 2.5 & 1.0 \\
\hline 08/05/03 & 117528 & 1.9 & 11.7 & 4.1 & 2.7 & 1.0 \\
\hline \multicolumn{7}{|c|}{ Recovery Field VER-3 } \\
\hline 08/06/03 & 117599 & 0.1 & 0 & 0.1 & 0.0 & 0.0 \\
\hline $08 / 12 / 03$ & 120139 & 0.4 & 0 & 0.5 & 0.0 & 0.0 \\
\hline 08/26/03 & 128703 & 0.6 & 0 & 0.0 & 0.0 & 0.0 \\
\hline 09/03/03 & 135198 & 0.6 & 0.9 & 0.6 & 0.0 & 0.0 \\
\hline \multicolumn{7}{|c|}{ Recovery Field VER-4 } \\
\hline $09 / 04 / 03$ & 135198 & 3.6 & 1.9 & 0.5 & 0.0 & 0.0 \\
\hline 09/11/03 & 158645 & 3.6 & 6.6 & 2.4 & 0.8 & 0.3 \\
\hline $09 / 24 / 03$ & 176000 & 3.4 & 5.4 & 2.7 & 0.9 & 0.4 \\
\hline $10 / 03 / 03$ & 207888 & 3.4 & 5.4 & 2.1 & 1.4 & 0.6 \\
\hline $10 / 08 / 03$ & 231847 & 3.6 & 6.1 & 2.8 & 1.1 & 0.5 \\
\hline $10 / 15 / 03$ & 246824 & 3.1 & 6.1 & 2.8 & 0.8 & 0.3 \\
\hline \multicolumn{7}{|c|}{ Recovery Field VER-2 } \\
\hline $10 / 17 / 03$ & 248231 & 0.9 & 24.9 & 11.6 & 0.3 & 0.1 \\
\hline $10 / 22 / 03$ & 257319 & 1.4 & 24.7 & 12.9 & 1.9 & 0.9 \\
\hline $10 / 29 / 03$ & 261330 & 1.7 & 35.2 & 15.3 & 1.0 & 0.5 \\
\hline $11 / 01 / 03$ & 271190 & 2.4 & 35.2 & 15.3 & 2.9 & 1.3 \\
\hline Total & 269,981 & & & & 45.5 & 21.4 \\
\hline
\end{tabular}




\section{CONTAMINANT RECOVERY}

TPH - Liquid Phase 2004 Season

\begin{tabular}{|c|c|c|c|c|c|c|}
\hline Date & $\begin{array}{c}\text { Totalizer } \\
\text { (gal) }\end{array}$ & $\begin{array}{l}\text { Flow } \\
\text { (gpm) }\end{array}$ & $\begin{array}{c}\mathrm{TPH}_{\text {water }} \\
\mathrm{mg} / \mathrm{l}\end{array}$ & $\begin{array}{c}\text { BTEX }_{\text {water }} \\
\text { mg/l }\end{array}$ & $\begin{array}{c}\mathrm{TPH}_{\text {mass }} \\
\text { (lb) }\end{array}$ & $\begin{array}{c}\text { BTEX }_{\text {mass }} \\
\text { (lb) }\end{array}$ \\
\hline & \multicolumn{6}{|c|}{ Recovery Field VER-2 } \\
\hline 06/01/04 & 20023 & & & & & \\
\hline $06 / 02 / 04$ & 21000 & 0.9 & 106.8 & 51.6 & 0.9 & 0.4 \\
\hline $06 / 03 / 04$ & 23899 & 2.3 & 25.46 & 14.1 & 1.6 & 0.8 \\
\hline 06/09/04 & 43763 & 4.2 & 30.65 & 14.9 & 4.7 & 2.4 \\
\hline $06 / 17 / 04$ & 56642 & 1.6 & 26.35 & 14.5 & 3.1 & 1.6 \\
\hline $06 / 22 / 04$ & 64260 & 2.0 & 21.29 & 10.9 & 1.5 & 0.8 \\
\hline $06 / 29 / 04$ & 76025 & 2.0 & 19.31 & 11.0 & 2.0 & 1.1 \\
\hline $07 / 07 / 04$ & 92489 & 2.3 & 11.44 & 4.9 & 2.1 & 1.1 \\
\hline \multirow[t]{2}{*}{ 07/08/04 } & 97495 & 2.6 & 11.44 & 4.9 & 0.5 & 0.2 \\
\hline & \multicolumn{6}{|c|}{ Recovery Field VER-1 } \\
\hline $07 / 14 / 04$ & 97495 & & & & & \\
\hline $07 / 14 / 04$ & 97546 & 0.1 & 5.49 & 2.2 & 0.0 & 0.0 \\
\hline $07 / 20 / 04$ & 102139 & 0.9 & 14.48 & 7.0 & 0.4 & 0.2 \\
\hline $07 / 27 / 04$ & 109470 & 0.7 & 11.44 & 4.9 & 0.8 & 0.4 \\
\hline 08/05/04 & 119231 & 0.7 & 11.04 & 4.3 & 0.9 & 0.4 \\
\hline 08/11/04 & 125570 & 0.7 & 8.89 & 3.5 & 0.5 & 0.2 \\
\hline 08/17/04 & 132269 & 0.7 & 6.23 & 2.3 & 0.4 & 0.2 \\
\hline $08 / 23 / 04$ & 137900 & 0.7 & 5.41 & 2.0 & 0.3 & 0.1 \\
\hline \multirow[t]{2}{*}{$08 / 31 / 04$} & 148414 & 0.8 & 4.32 & 1.4 & 0.4 & 0.1 \\
\hline & \multicolumn{6}{|c|}{ Recovery Field VER-4 } \\
\hline $09 / 14 / 04$ & 320 & & & & & \\
\hline 09/15/04 & 8698 & 4.0 & 1.89 & 0.6 & 0.1 & 0.0 \\
\hline $09 / 22 / 04$ & 19327 & 5.5 & 1.62 & 0.6 & 0.2 & 0.1 \\
\hline $10 / 01 / 04$ & 63514 & 4.6 & 0.79 & 0.3 & 0.4 & 0.2 \\
\hline $10 / 07 / 04$ & 101067 & 4.5 & 0.78 & 0.4 & 0.2 & 0.1 \\
\hline Total & 229,138 & & & & 21.0 & 10.2 \\
\hline
\end{tabular}


APPENDIX D-2

\section{CONTAMINANT RECOVERY - VAPOR PHASE}




\section{CONTAMINANT RECOVERY}

TPH - Vapor Phase 2003 Season

\begin{tabular}{|c|c|c|c|c|c|c|c|}
\hline Date & $\begin{array}{l}\text { Runtime } \\
\text { (cum. h) }\end{array}$ & $\begin{array}{c}Q_{\text {air }} \\
(\mathrm{cfm})\end{array}$ & $\begin{array}{l}\text { Volume } \\
\left(1000 \mathrm{ft}^{3}\right)\end{array}$ & $\begin{array}{c}\mathrm{TPH}_{\text {air }}{ }^{1} \\
\left(\mathrm{mg} / \mathrm{m}^{3}\right)\end{array}$ & $\begin{array}{l}\text { BTEX }_{\text {air }}{ }^{1} \\
\left(\mathrm{mg} / \mathrm{m}^{3}\right)\end{array}$ & $\begin{array}{c}\mathrm{TPH}_{\text {mass }} \\
\text { (lb) }\end{array}$ & $\begin{array}{c}\text { BTEX } \\
\text { (lb) }\end{array}$ \\
\hline & \multicolumn{7}{|c|}{ Recovery Field VER-1 } \\
\hline $06 / 10 / 03$ & 5.3 & 47.6 & 15 & 75,700 & 555.5 & 72.0 & 0.5 \\
\hline $06 / 11 / 03$ & 22.5 & 47.6 & 49 & 91,450 & 871.5 & 255.9 & 2.2 \\
\hline $06 / 19 / 03$ & 201.9 & 47.2 & 508 & 47,400 & 631.0 & 2201.6 & 23.7 \\
\hline $06 / 24 / 03$ & 327.3 & 42.2 & 317 & 36,850 & 1091.5 & 834.9 & 17.0 \\
\hline $07 / 01 / 03$ & 478.8 & 42.1 & 383 & 30,000 & 921.5 & 798.5 & 23.9 \\
\hline $07 / 10 / 03$ & 670.8 & 37.4 & 431 & 31,800 & 1239.0 & 831.1 & 28.9 \\
\hline $07 / 16 / 03$ & 814.1 & 38.5 & 331 & 48,300 & 1345.0 & 828.1 & 26.6 \\
\hline $07 / 22 / 03$ & 959.4 & 40.6 & 354 & 46,350 & 610.0 & 1045.6 & 21.5 \\
\hline $07 / 29 / 03$ & 1119.3 & 40.5 & 388 & 31,450 & 846.0 & 943.2 & 17.5 \\
\hline \multirow[t]{2}{*}{$08 / 05 / 03$} & 1294.9 & 40.5 & 427 & 19,000 & 531.0 & 672.2 & 18.2 \\
\hline & \multicolumn{7}{|c|}{ Recovery Field VER-3 } \\
\hline $08 / 06 / 03$ & 1307.9 & 24.2 & 19 & 140 & 37.0 & 0.1 & 0.0 \\
\hline $08 / 12 / 03$ & 1412.6 & 41.3 & 259 & 0 & 0.0 & 1.1 & 0.3 \\
\hline $08 / 26 / 03$ & 1655.9 & 35.7 & 521 & 0 & 0.0 & 0.0 & 0.0 \\
\hline \multirow[t]{2}{*}{$09 / 03 / 03$} & 1841.8 & 37.6 & 419 & 0 & 0.0 & 0.0 & 0.0 \\
\hline & \multicolumn{7}{|c|}{ Recovery Field VER-4 } \\
\hline $09 / 04 / 03$ & 1844.3 & 36.6 & 6 & 7.195 & 30.0 & 1.3 & 0.0 \\
\hline $09 / 11 / 03$ & 1948.9 & 37.4 & 235 & 9,895 & 88.0 & 125.2 & 0.9 \\
\hline $09 / 24 / 03$ & 2034.4 & 37.9 & 194 & 2,835 & 43.0 & 77.2 & 0.8 \\
\hline $10 / 03 / 03$ & 2190.4 & 42.9 & 402 & 3,375 & 33.0 & 77.9 & 0.9 \\
\hline $10 / 08 / 03$ & 2302.7 & 41.9 & 282 & 3,735 & 41.0 & 62.6 & 0.6 \\
\hline \multirow[t]{2}{*}{$10 / 15 / 03$} & 2384.2 & 41.9 & 205 & 3,735 & 41.0 & 47.8 & 0.5 \\
\hline & \multicolumn{7}{|c|}{ Recovery Field VER-2 } \\
\hline $10 / 17 / 03$ & 2411.1 & 32.7 & 53 & 11,600 & 239.0 & 19.1 & 0.4 \\
\hline $10 / 22 / 03$ & 2516.6 & 39.1 & 248 & 16,650 & 416.0 & 218.4 & 5.0 \\
\hline $10 / 29 / 03$ & 2556.1 & 39.1 & 93 & 11,395 & 224.0 & 81.1 & 1.8 \\
\hline $11 / 01 / 03$ & 2623.2 & 39.0 & 157 & 11,395 & 224.0 & 111.7 & 2.2 \\
\hline Total & & & 6,296 & & & 9,306 & 193 \\
\hline
\end{tabular}




\section{CONTAMINANT RECOVERY}

TPH - Vapor Phase 2004 Season

\begin{tabular}{|c|c|c|c|c|c|c|c|}
\hline Date & $\begin{array}{l}\text { Runtime } \\
\text { (cum. h) }\end{array}$ & $\begin{array}{c}Q_{\text {air }} \\
(\mathrm{cfm})\end{array}$ & $\begin{array}{l}\text { Volume } \\
\left(1000 \mathrm{ft}^{3}\right)\end{array}$ & $\begin{array}{c}\mathrm{TPH}_{\mathrm{air}}{ }^{1} \\
\left(\mathrm{mg} / \mathrm{m}^{3}\right)\end{array}$ & $\begin{array}{l}\text { BTEX }_{\text {air }}{ }^{2} \\
\left(\mathrm{mg} / \mathrm{m}^{3}\right)\end{array}$ & $\begin{array}{c}\mathrm{TPH}_{\text {mass }} \\
\text { (lb) }\end{array}$ & $\begin{array}{c}\text { BTEX }_{\text {mass }} \\
\text { (lb) }\end{array}$ \\
\hline & \multicolumn{7}{|c|}{ Recovery Field VER-2 } \\
\hline $06 / 01 / 04$ & & & & 85,200 & 1661.4 & & \\
\hline $06 / 02 / 04$ & 18.0 & 32.2 & 35 & 85,200 & 1661.4 & 185.3 & 3.6 \\
\hline $06 / 03 / 04$ & 38.7 & 31.0 & 38 & 46,200 & 832.5 & 157.4 & 3.0 \\
\hline $06 / 09 / 04$ & 116.9 & 31.3 & 147 & 39,400 & 928.0 & 392.6 & 8.0 \\
\hline $06 / 17 / 04$ & 251.7 & 27.4 & 222 & 35,300 & 957.2 & 516.5 & 13.0 \\
\hline $06 / 29 / 04$ & 413.5 & 31.3 & 304 & 24,900 & 1060.3 & 571.3 & 19.0 \\
\hline $07 / 07 / 04$ & 535.3 & 31.3 & 229 & 25,000 & 829.8 & 430.5 & 13.4 \\
\hline \multirow[t]{2}{*}{$07 / 08 / 04$} & 568.0 & 31.3 & 61 & 25,000 & 830.3 & 114.7 & 3.2 \\
\hline & \multicolumn{7}{|c|}{ Recovery Field VER-1 } \\
\hline $07 / 14 / 04$ & 580.9 & 35.6 & 28 & 34,850 & 137.0 & 40.2 & 0.2 \\
\hline $07 / 20 / 04$ & 667.5 & 59.2 & 308 & 27,250 & 862.5 & 321.6 & 9.5 \\
\hline $07 / 27 / 04$ & 838.5 & 40.4 & 415 & 19,550 & 611.1 & 335.7 & 19.0 \\
\hline $08 / 05 / 04$ & 1060.3 & 40.8 & 543 & 13,950 & 424.5 & 374.5 & 17.4 \\
\hline $08 / 11 / 04$ & 1202.3 & 40.8 & 348 & 12,000 & 282.7 & 290.8 & 7.6 \\
\hline $08 / 17 / 04$ & 1351.7 & 40.6 & 364 & 10,100 & 233.4 & 344.8 & 5.8 \\
\hline $08 / 23 / 04$ & 1484.5 & 60.2 & 480 & 16,700 & 801.0 & 219.3 & 15.4 \\
\hline \multirow{2}{*}{$08 / 31 / 04$} & 1693.1 & 59.8 & 748 & 13,650 & 665.5 & 26.8 & 34.1 \\
\hline & \multicolumn{7}{|c|}{ Recovery Field VER-4 } \\
\hline $09 / 15 / 04$ & 1727.6 & 21.1 & 44 & 995 & 66.9 & 2.6 & 0.2 \\
\hline $10 / 22 / 03$ & 1759.8 & 21.1 & 41 & 151 & 7.7 & 0.6 & 0.1 \\
\hline $10 / 29 / 03$ & 1920.3 & 23.0 & 222 & 1,380 & 25.5 & 0.0 & 0.2 \\
\hline $11 / 01 / 03$ & 2060.9 & 22.8 & 192 & 510 & 10.3 & 0.0 & 0.2 \\
\hline Total & & & 4,766 & & & 4,325 & 173 \\
\hline
\end{tabular}


APPENDIX D-3

\section{INJECTION SYSTEM}




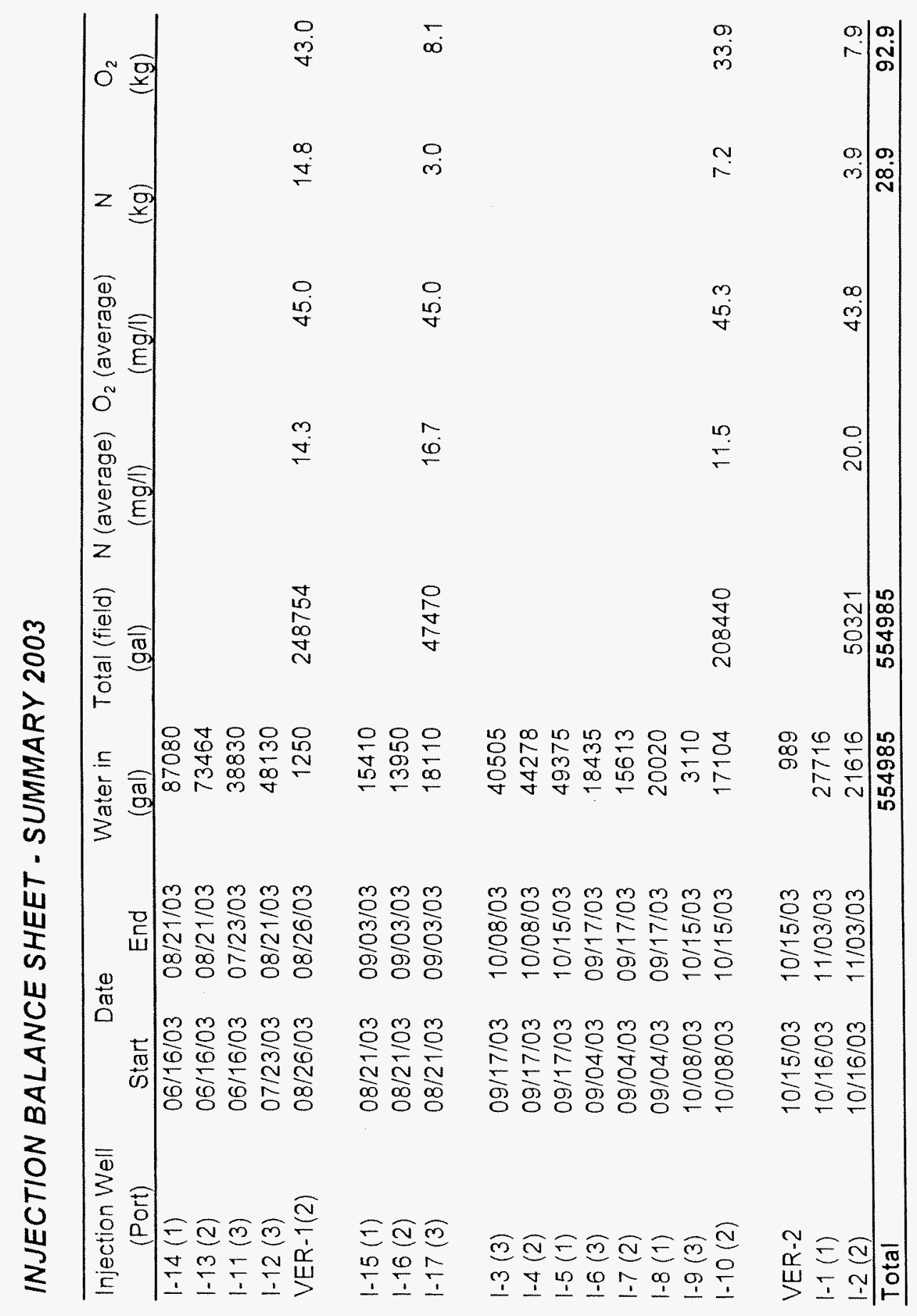




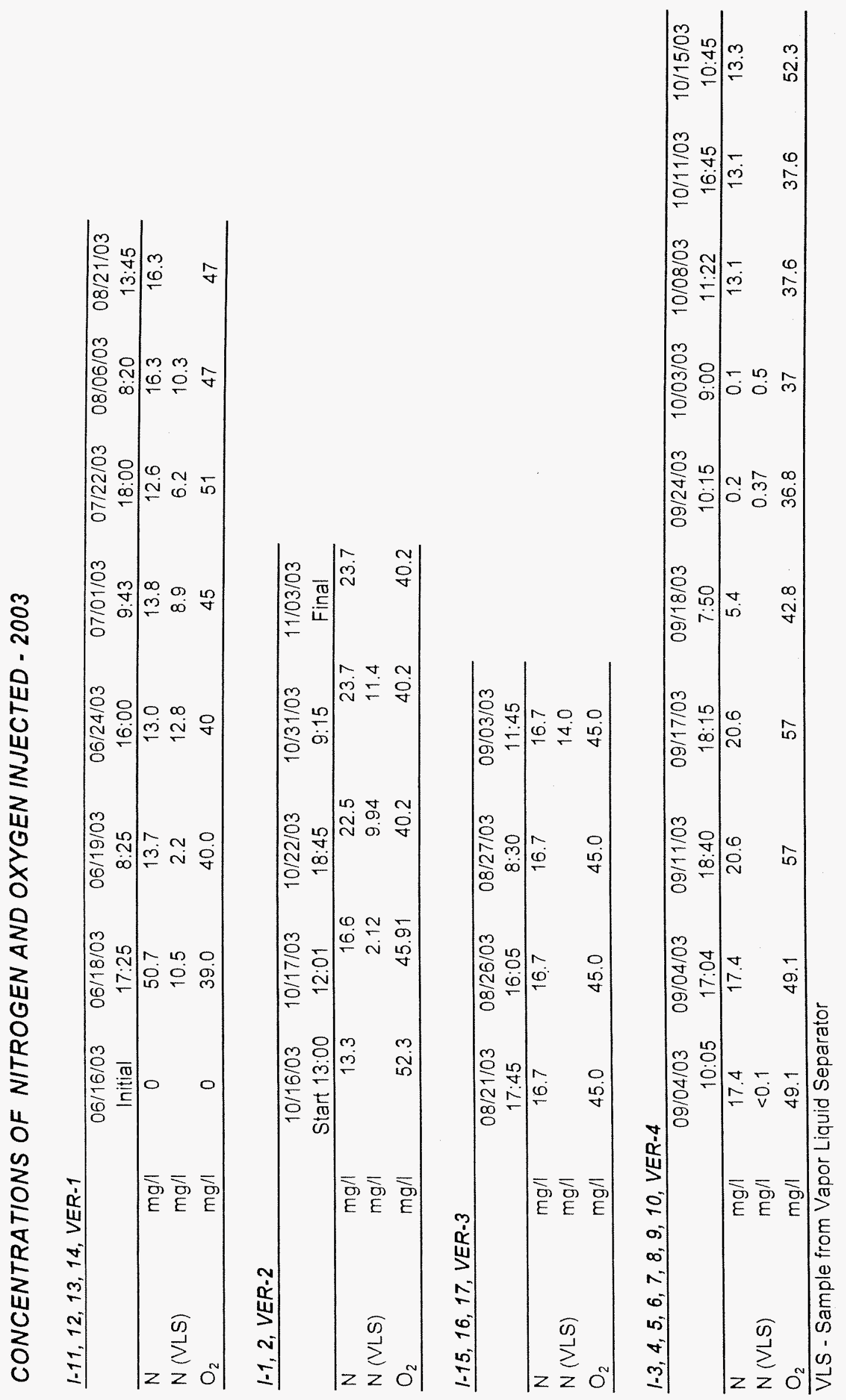




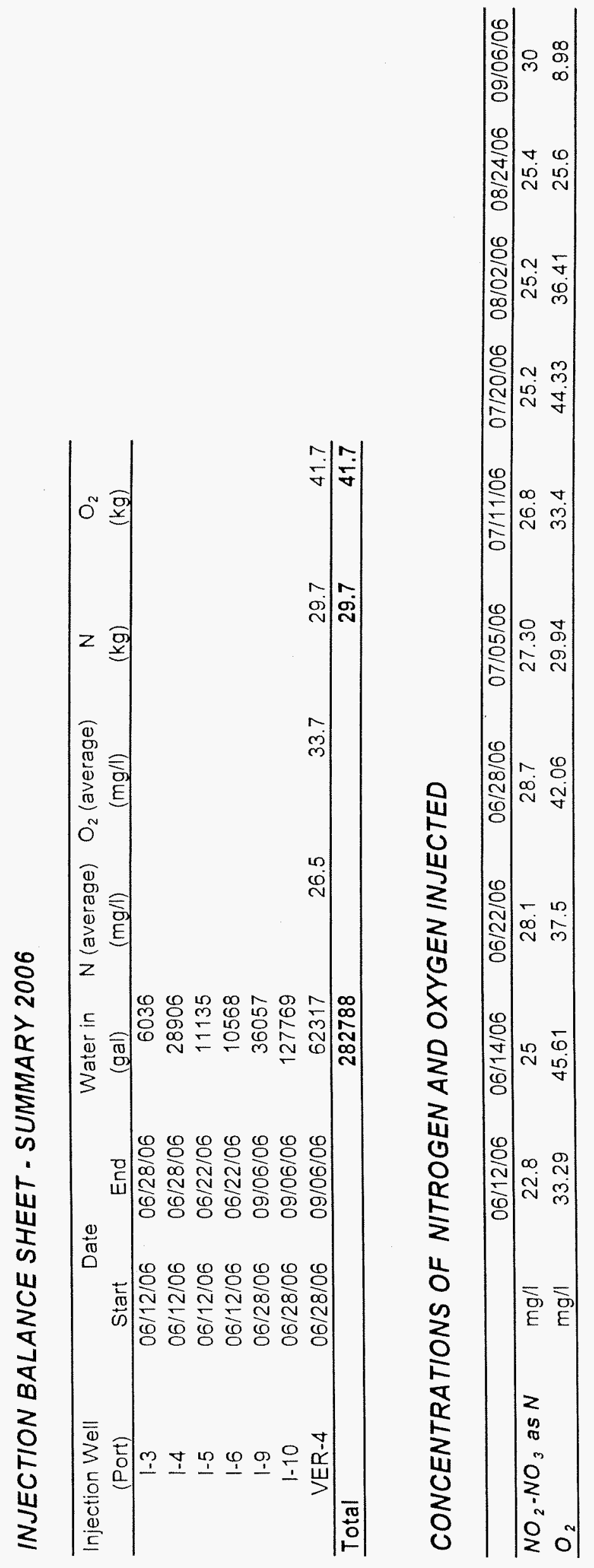




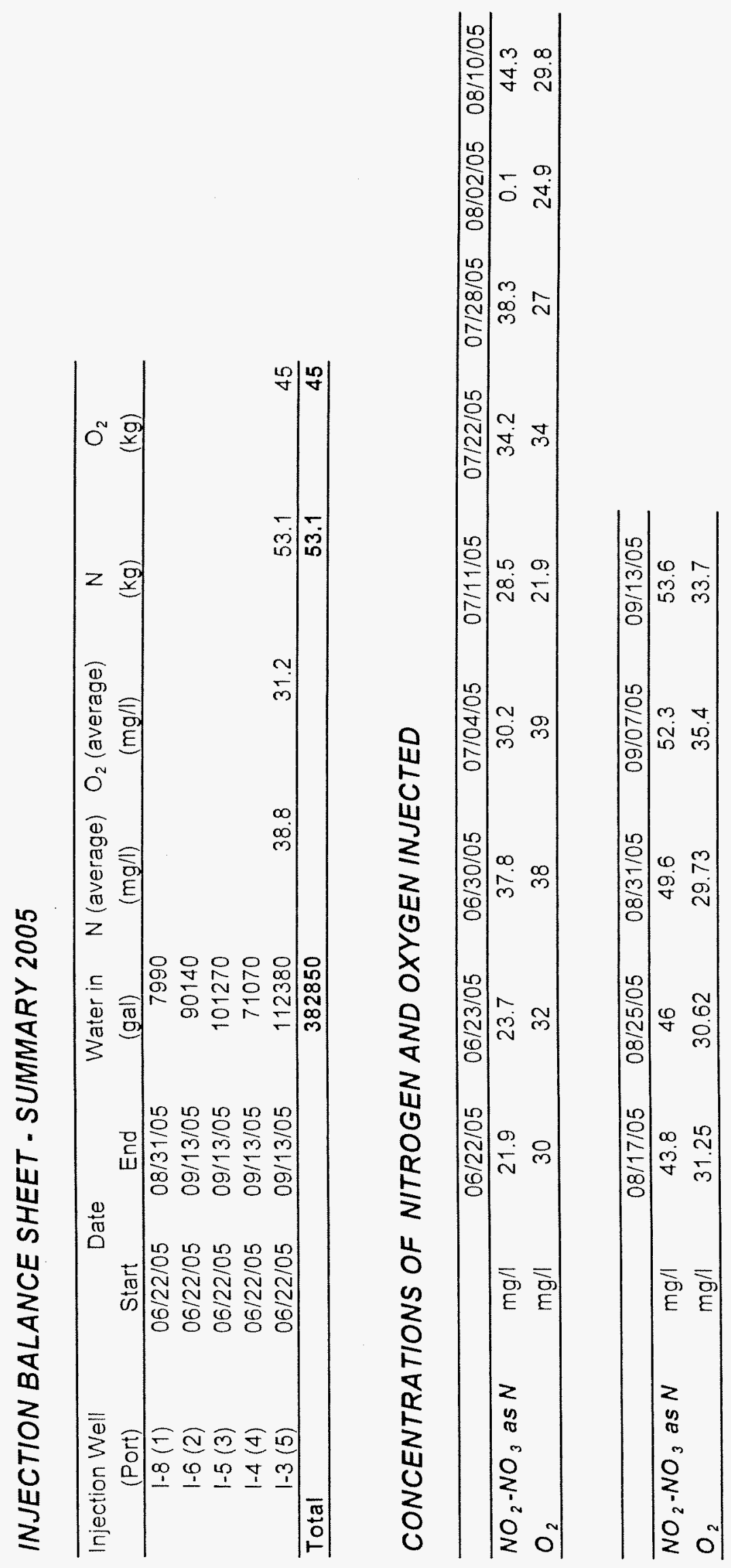




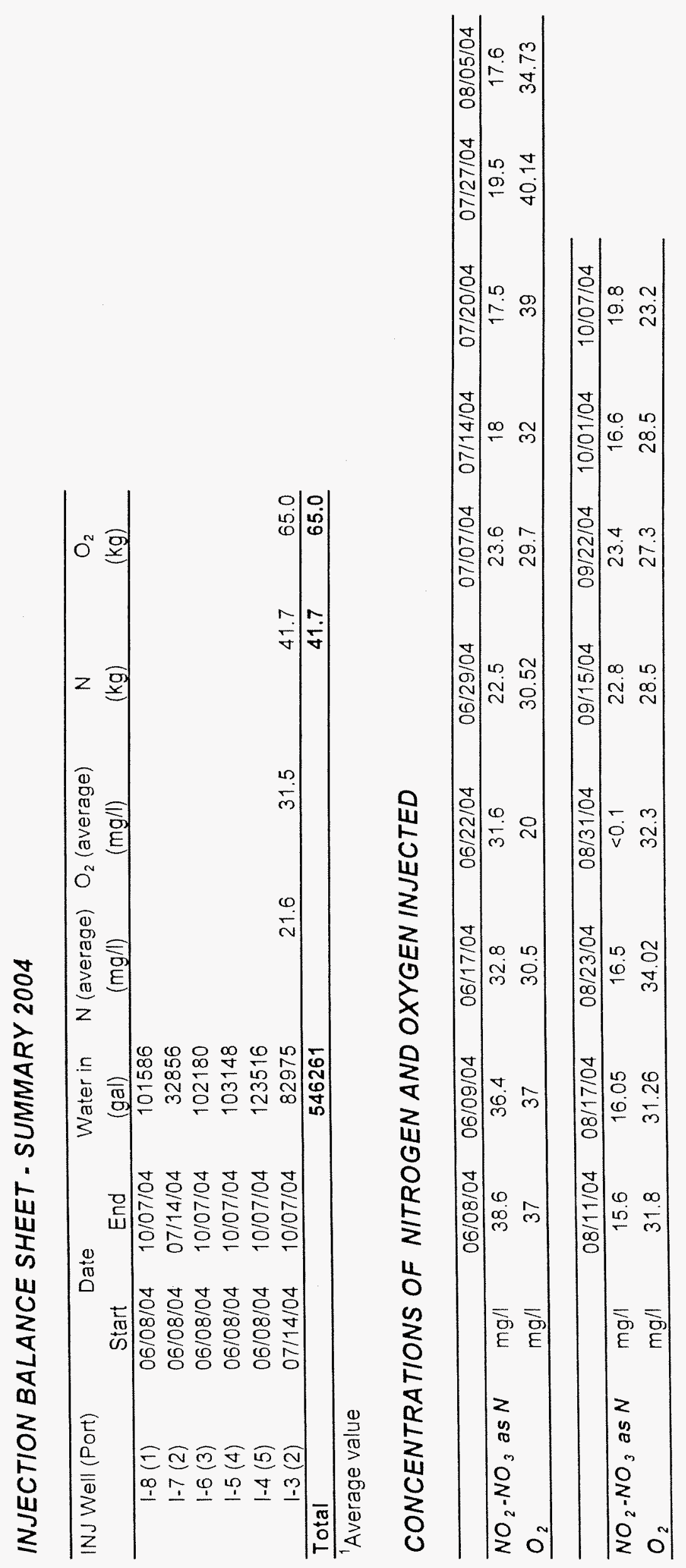


APPENDIX E

\section{SUMMARY OF DATA - SYSTEM MONITORING}


APPENDIX E-1

WATER QUALITY 


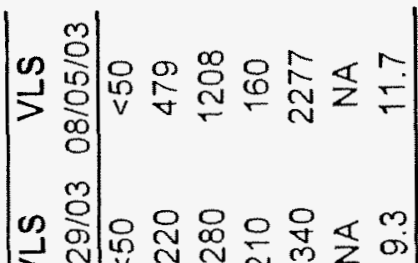

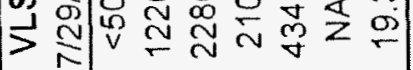

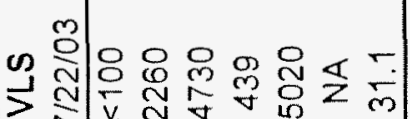

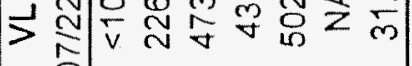

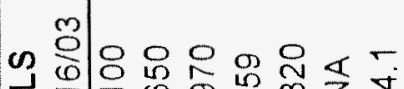

等

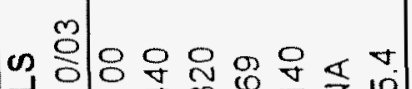

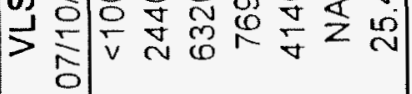

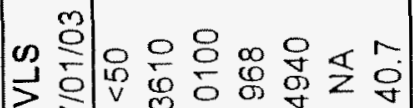

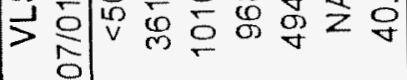

๓

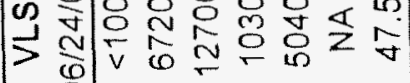

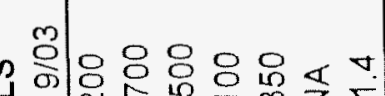

$\%>\overline{0}$

$\stackrel{2}{2}$

更

य > क्षे v

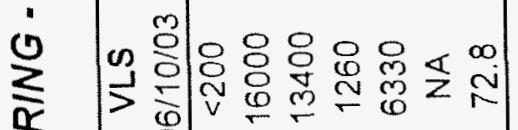

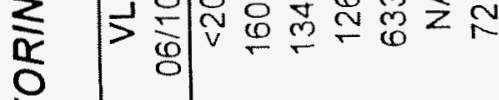

\&

\section{है}

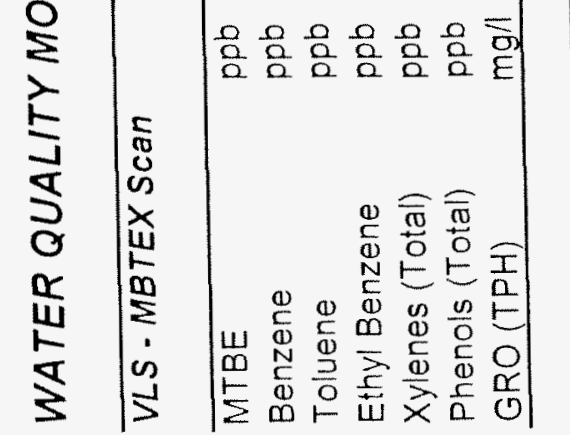

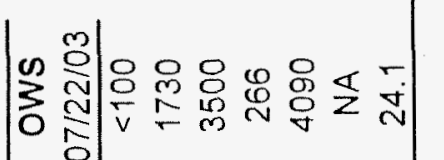

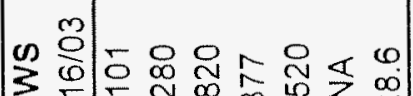

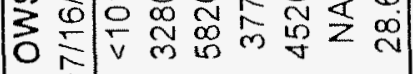

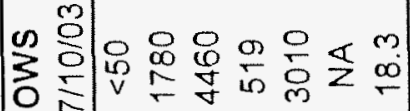

ठ․․ำ

路

3.

等

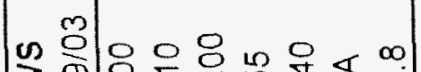

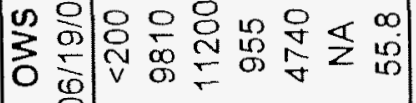

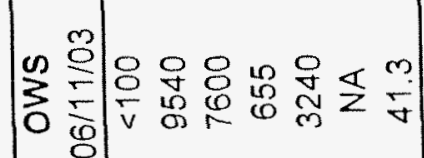

๓

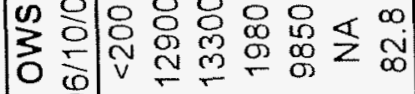

ㅇ

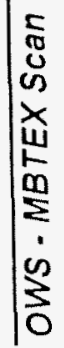

응응응응응응항 으을

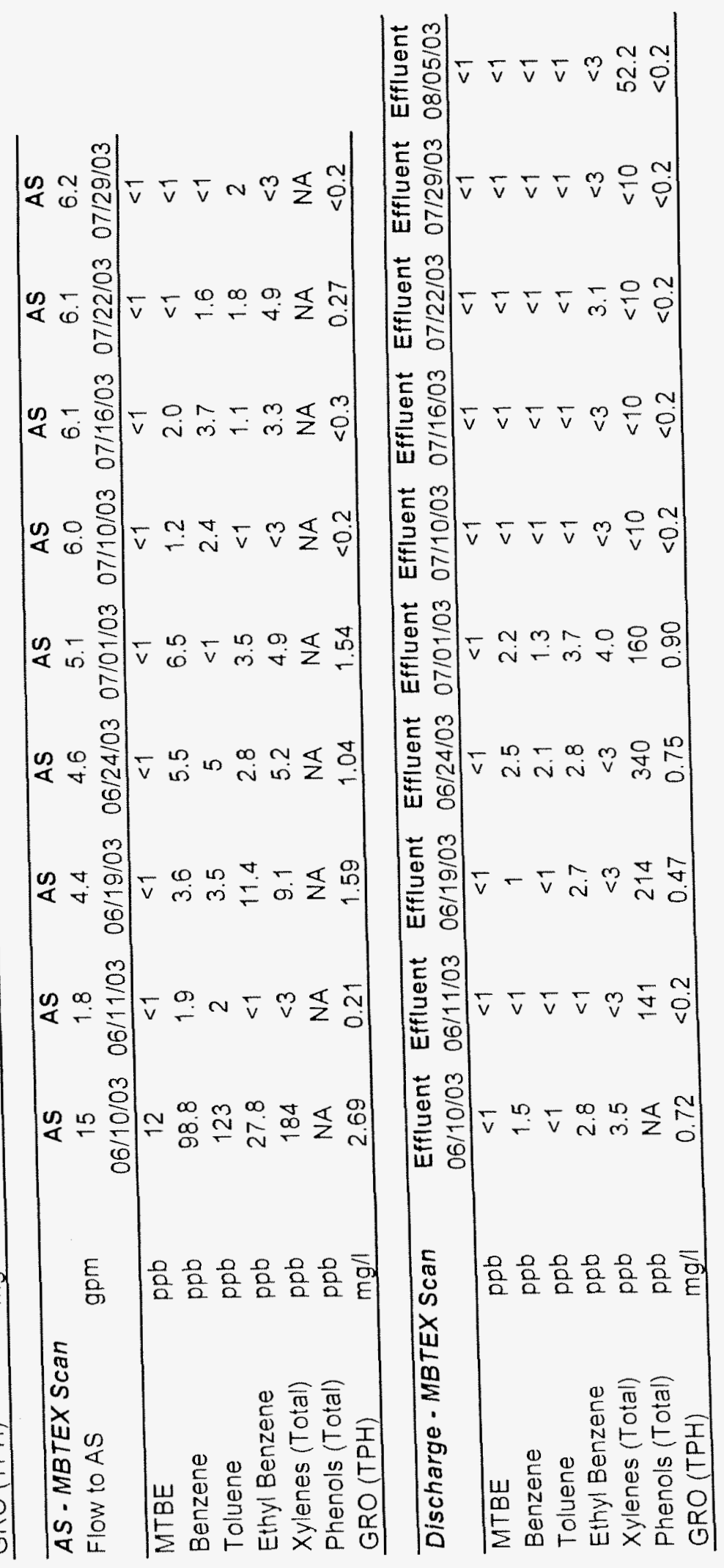




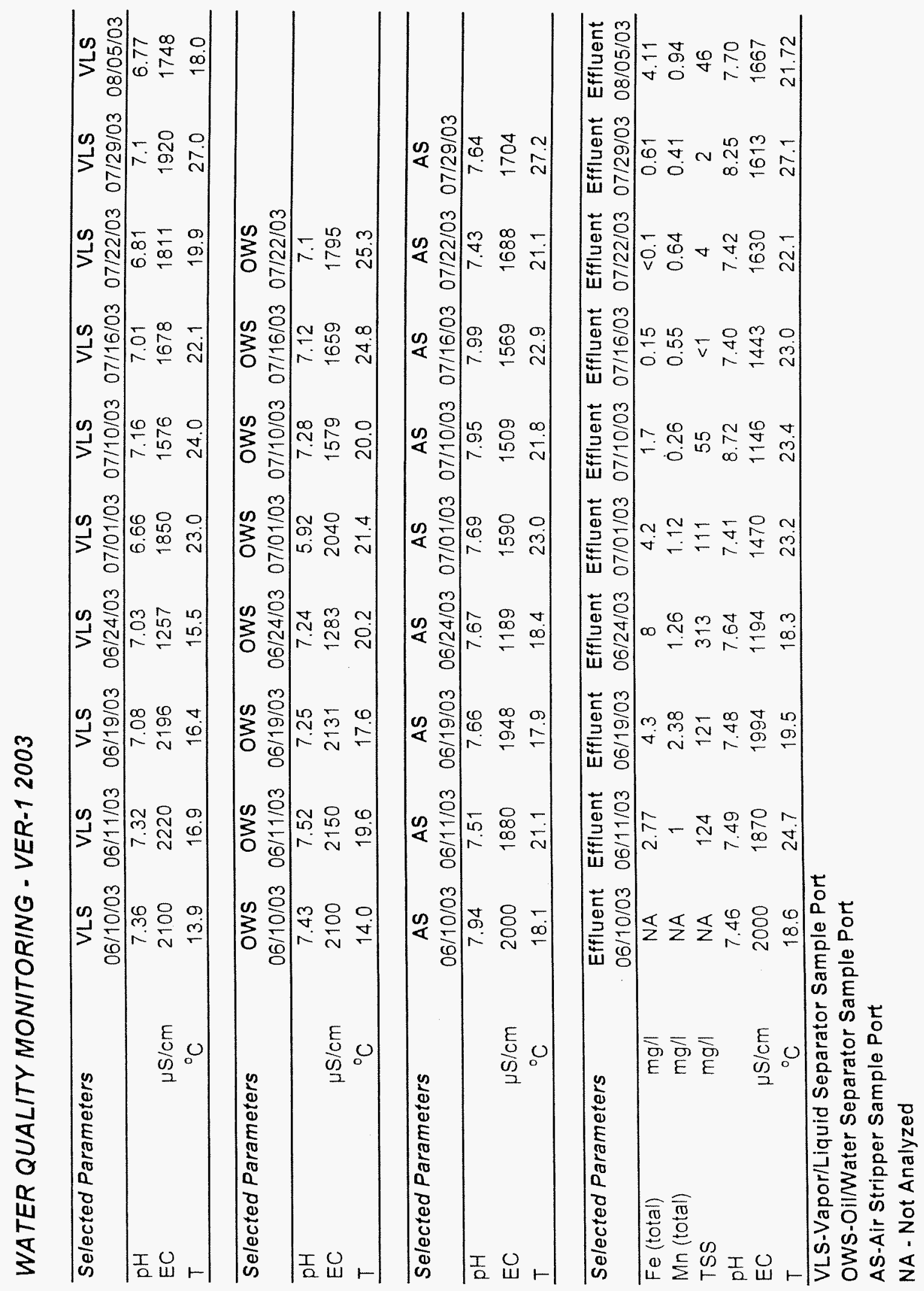




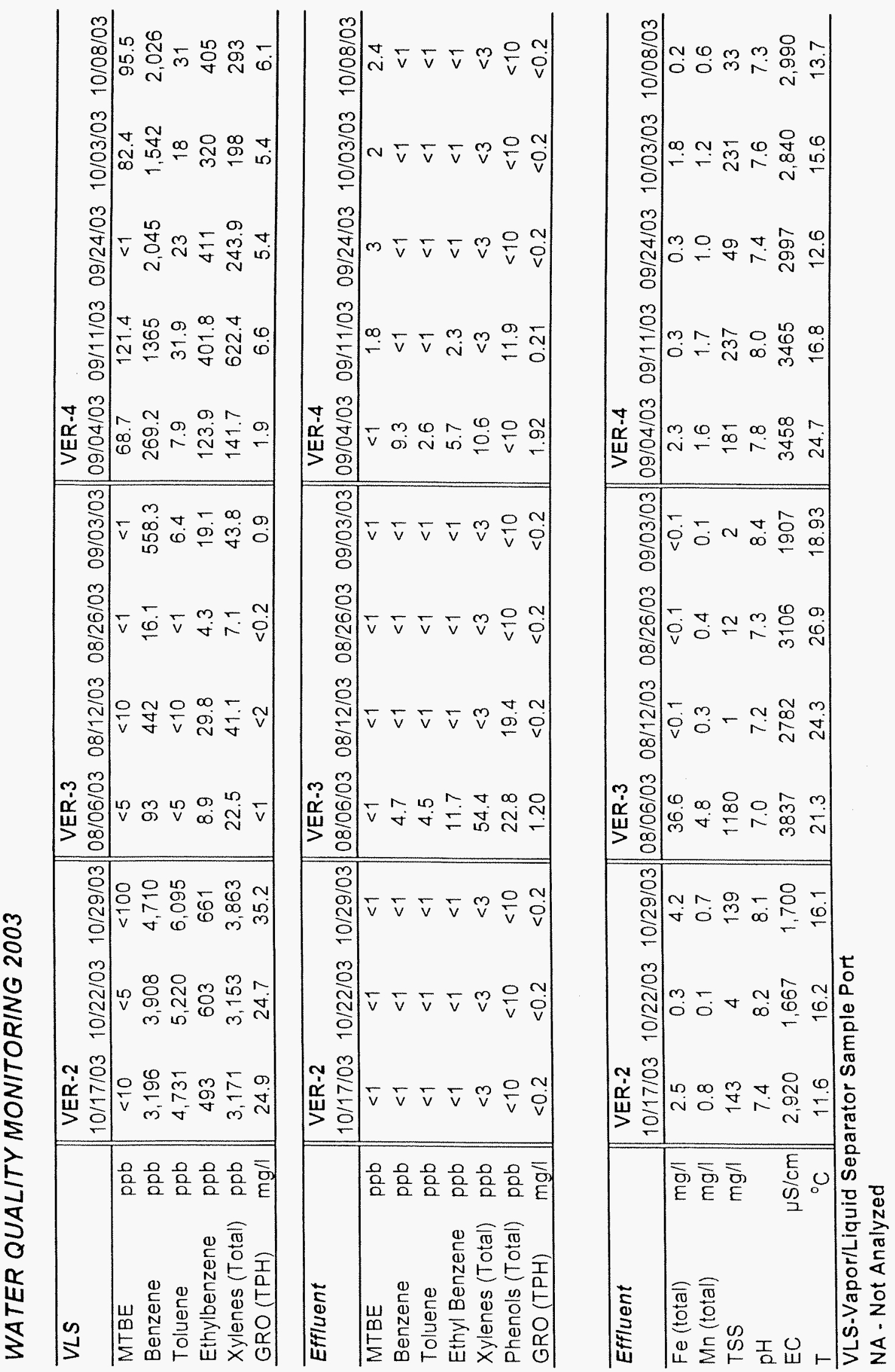



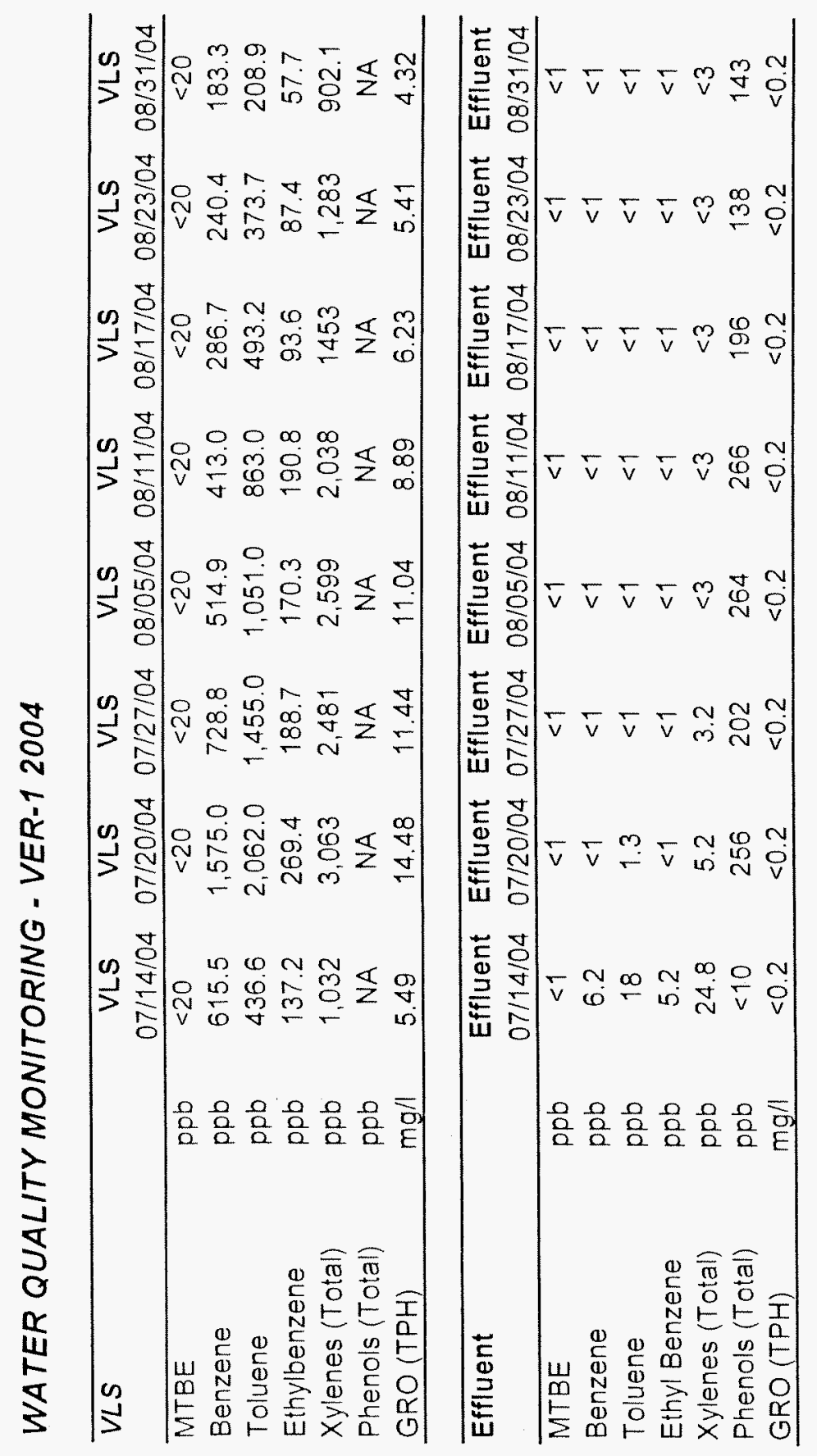

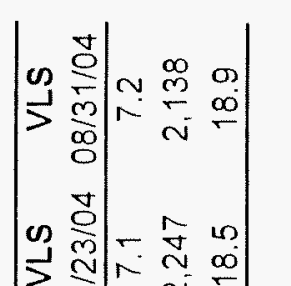

$>\underset{\infty}{\infty} \sim$

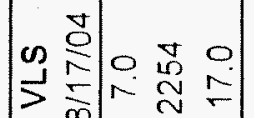

$>\frac{}{\infty}$

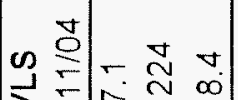

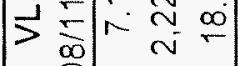

u \begin{tabular}{llll}
0 & 0 & 0 & - \\
\hline 10 & 0 & 0 & -
\end{tabular}

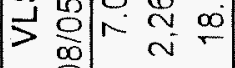

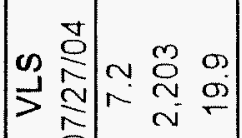

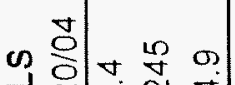

$>\underset{N}{N} \stackrel{N}{N}$

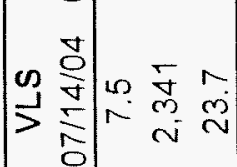

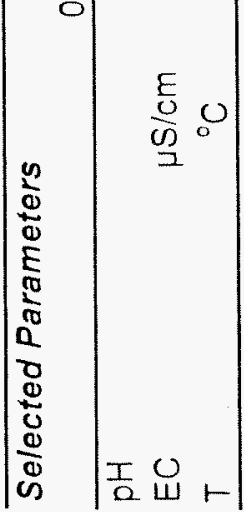

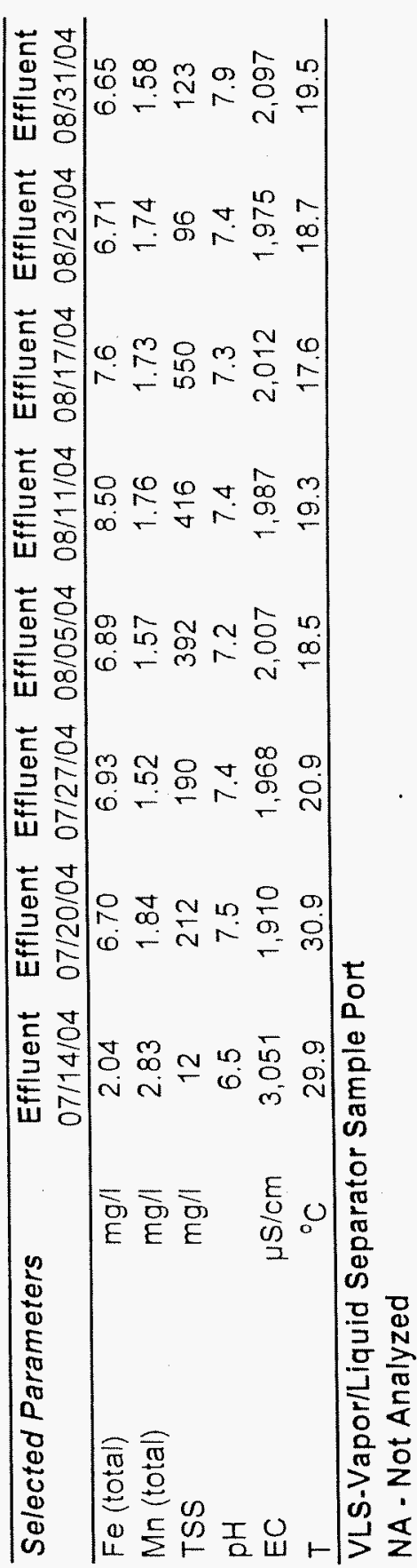




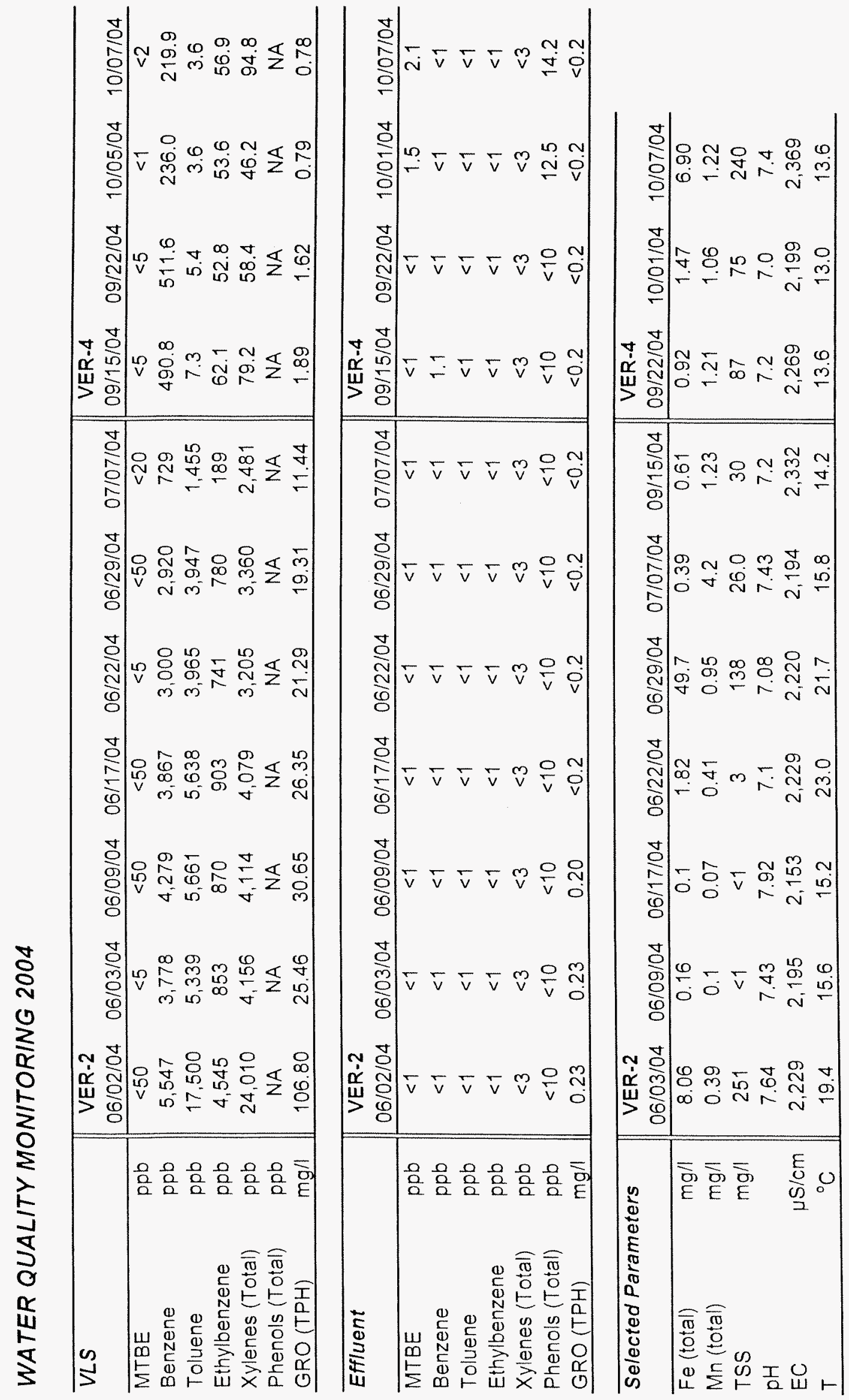


APPENDIX E-2

OFFGAS QUALITY 


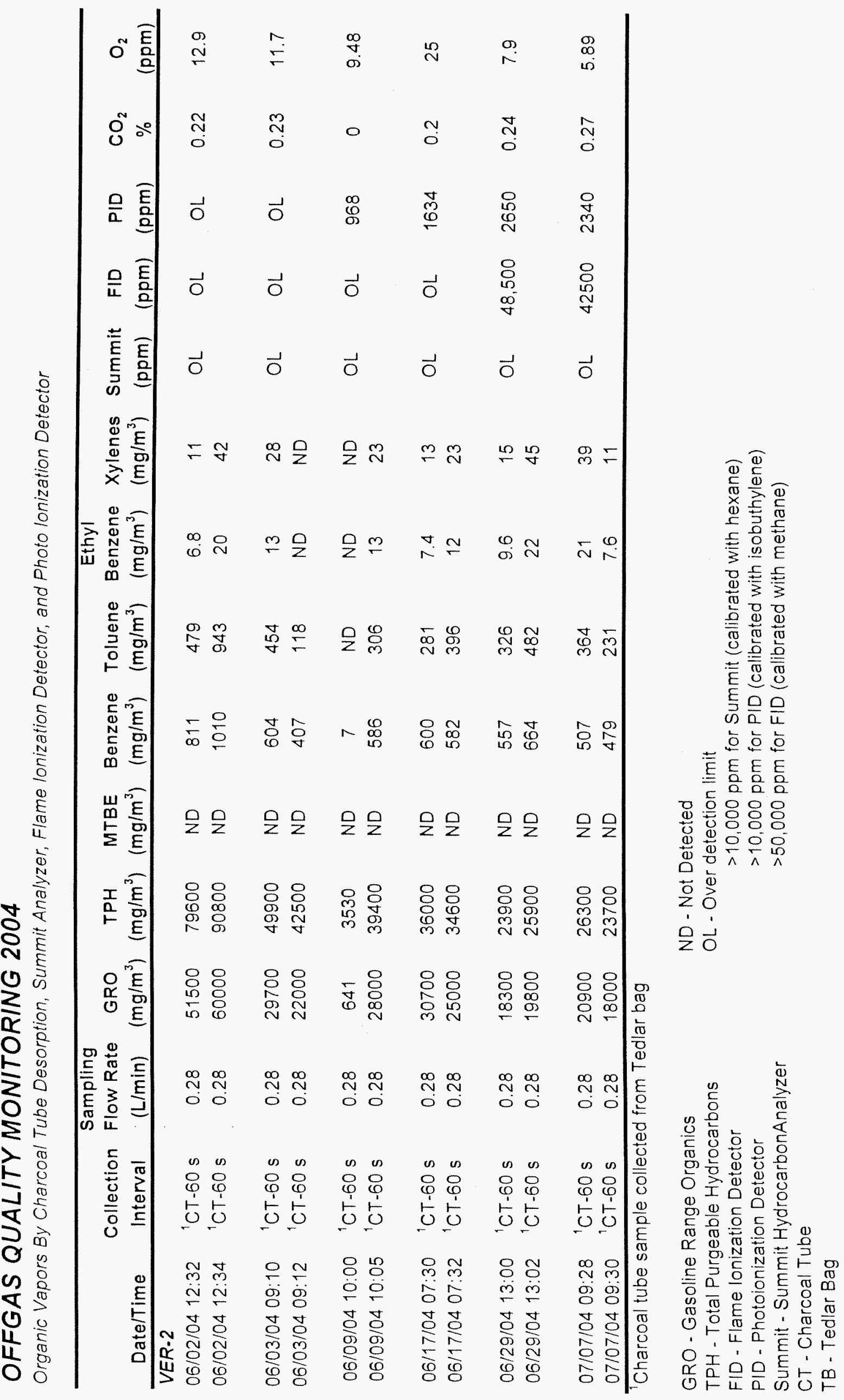




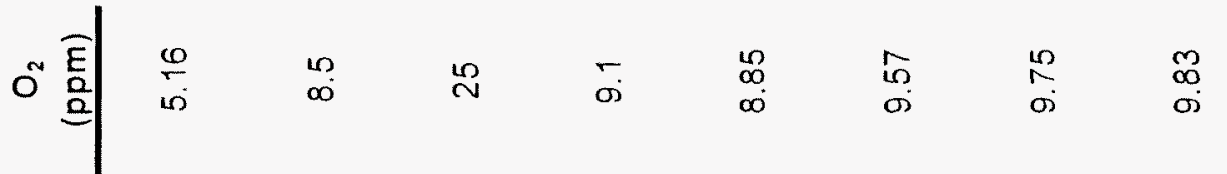

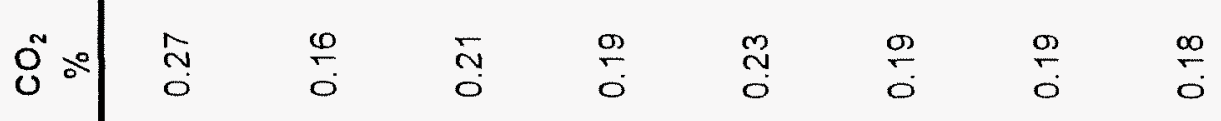

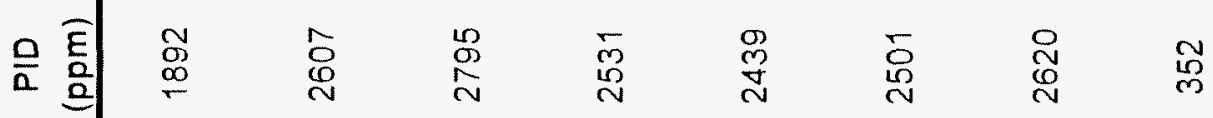

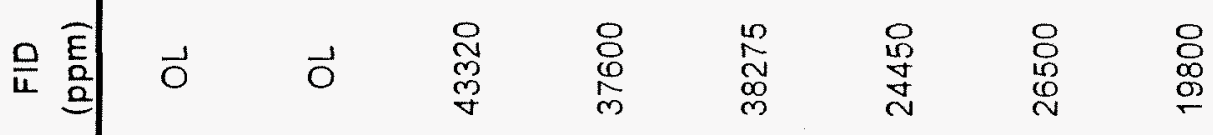

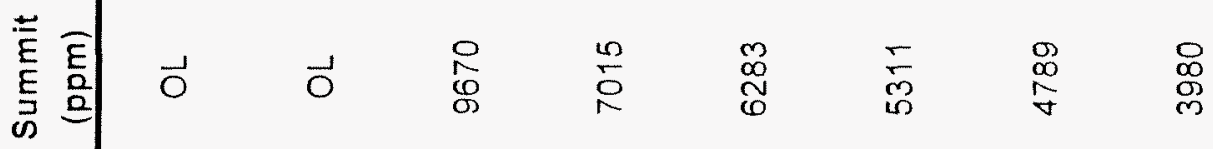

5
0
0
0
0
0
0
$\frac{0}{0}$
$\frac{0}{0}$
$\frac{\pi}{1}$
0
0
0
0
0
0

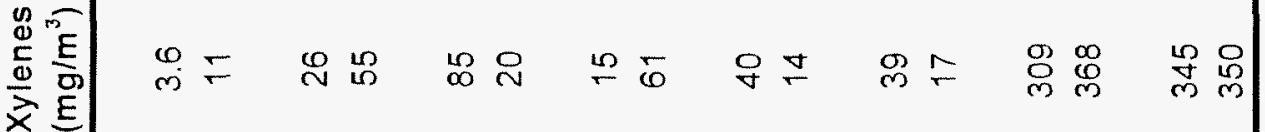

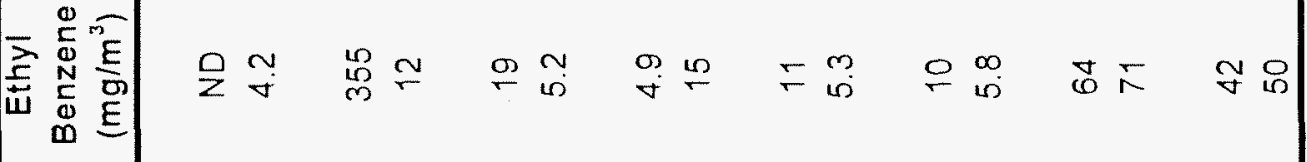

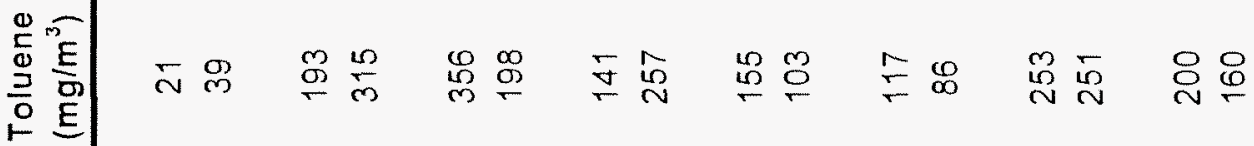

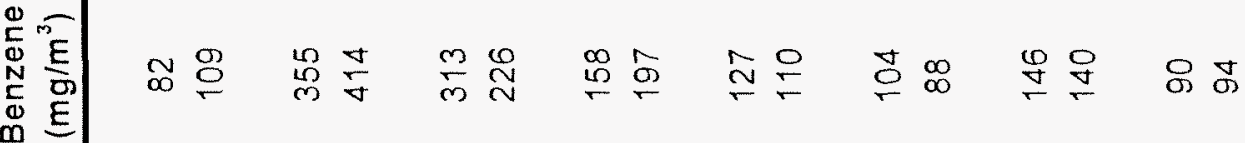

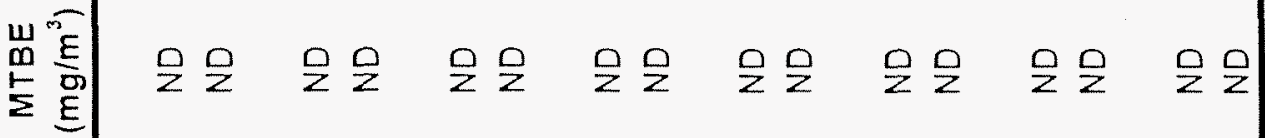

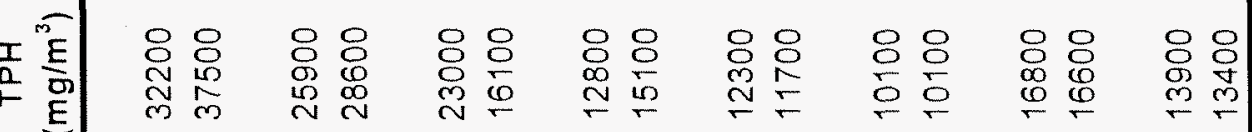

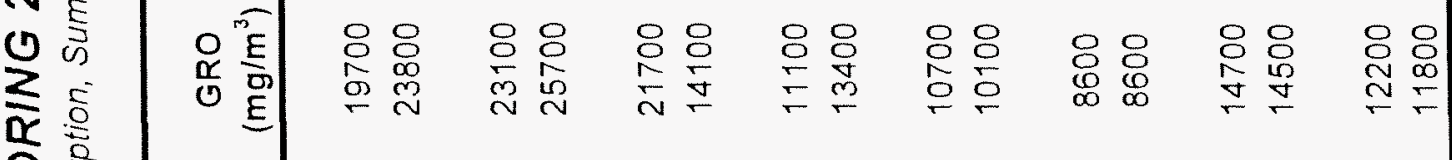

02

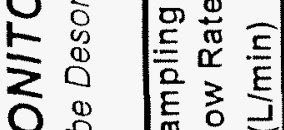

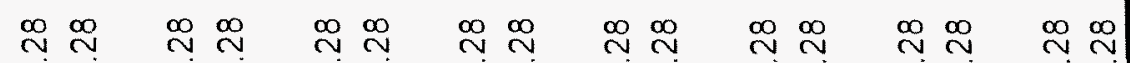

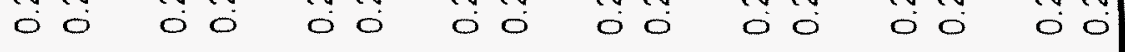

$\Sigma F$

$>\overline{0}$

I

प⿺辶寸

$\overrightarrow{\mathrm{O}}$ के

u

व

0.0

夜

0

为 은

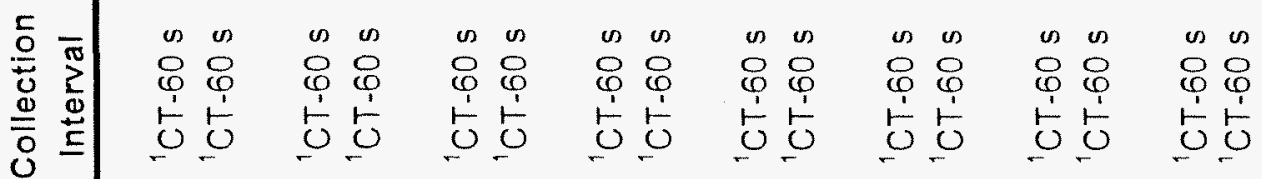

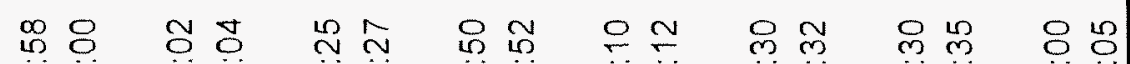

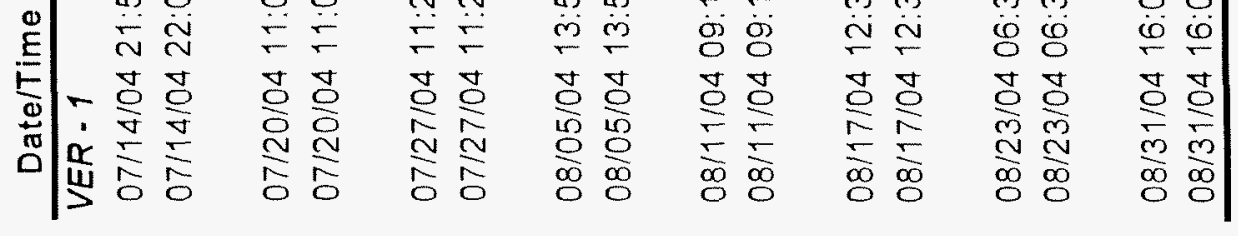




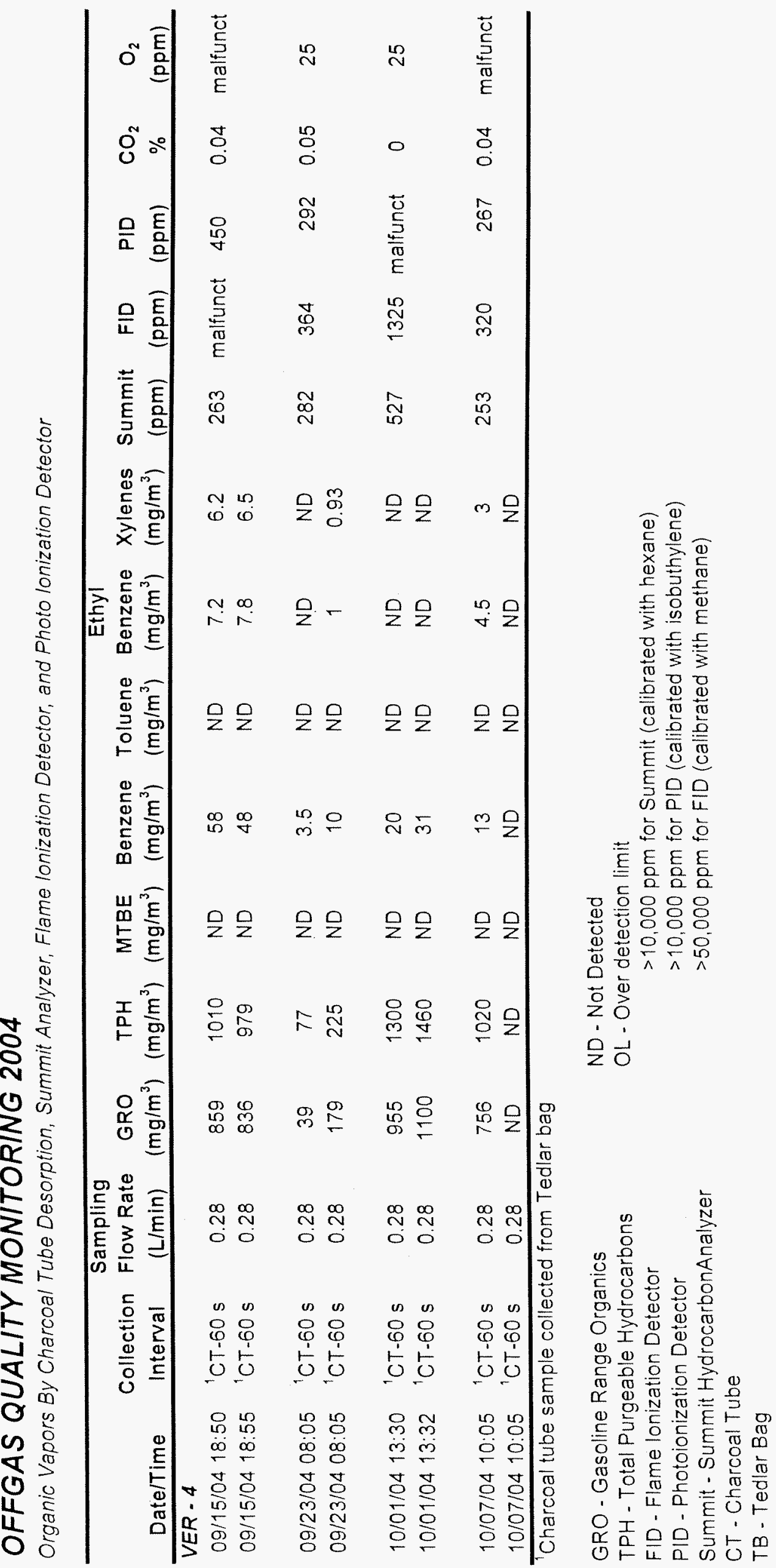




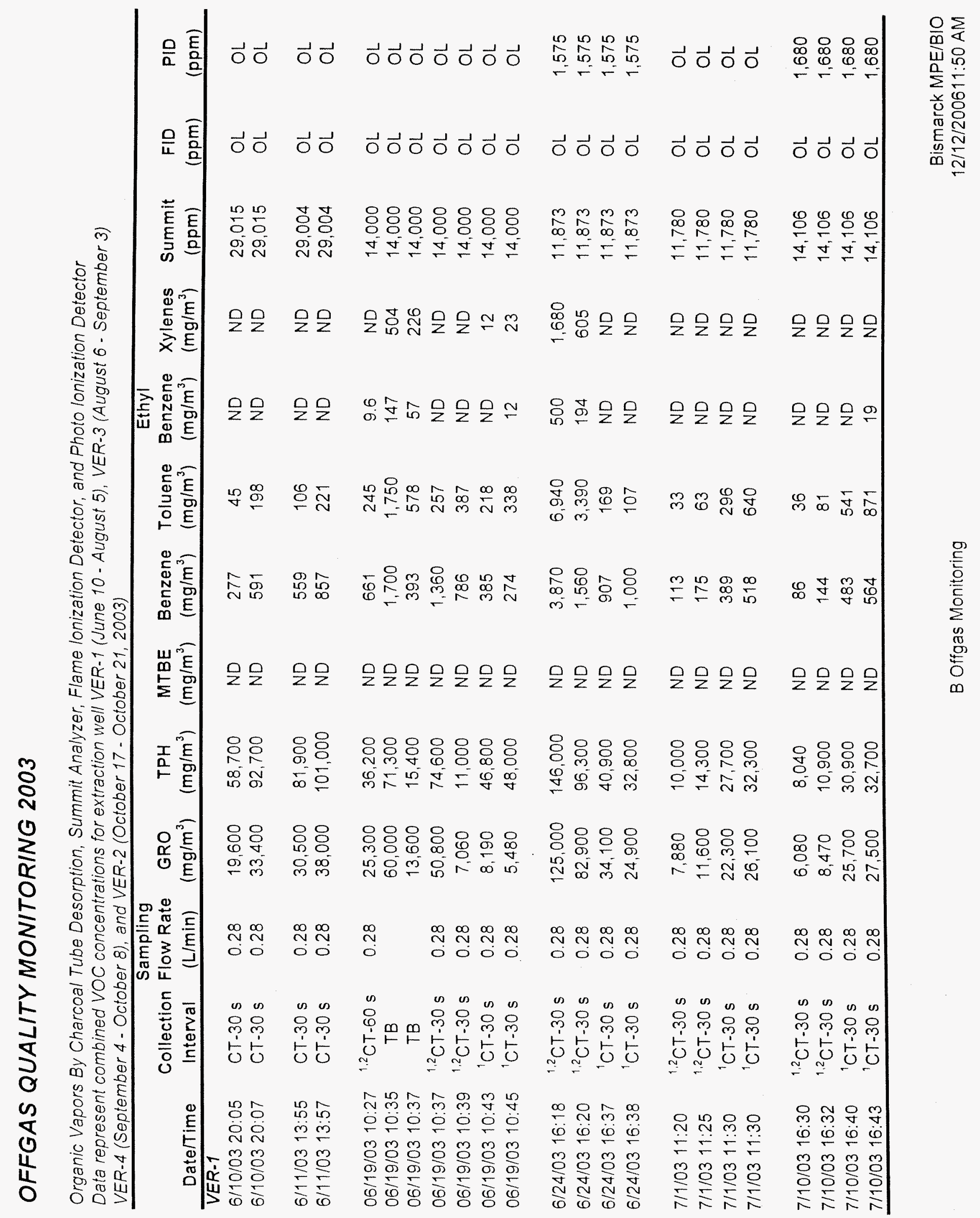




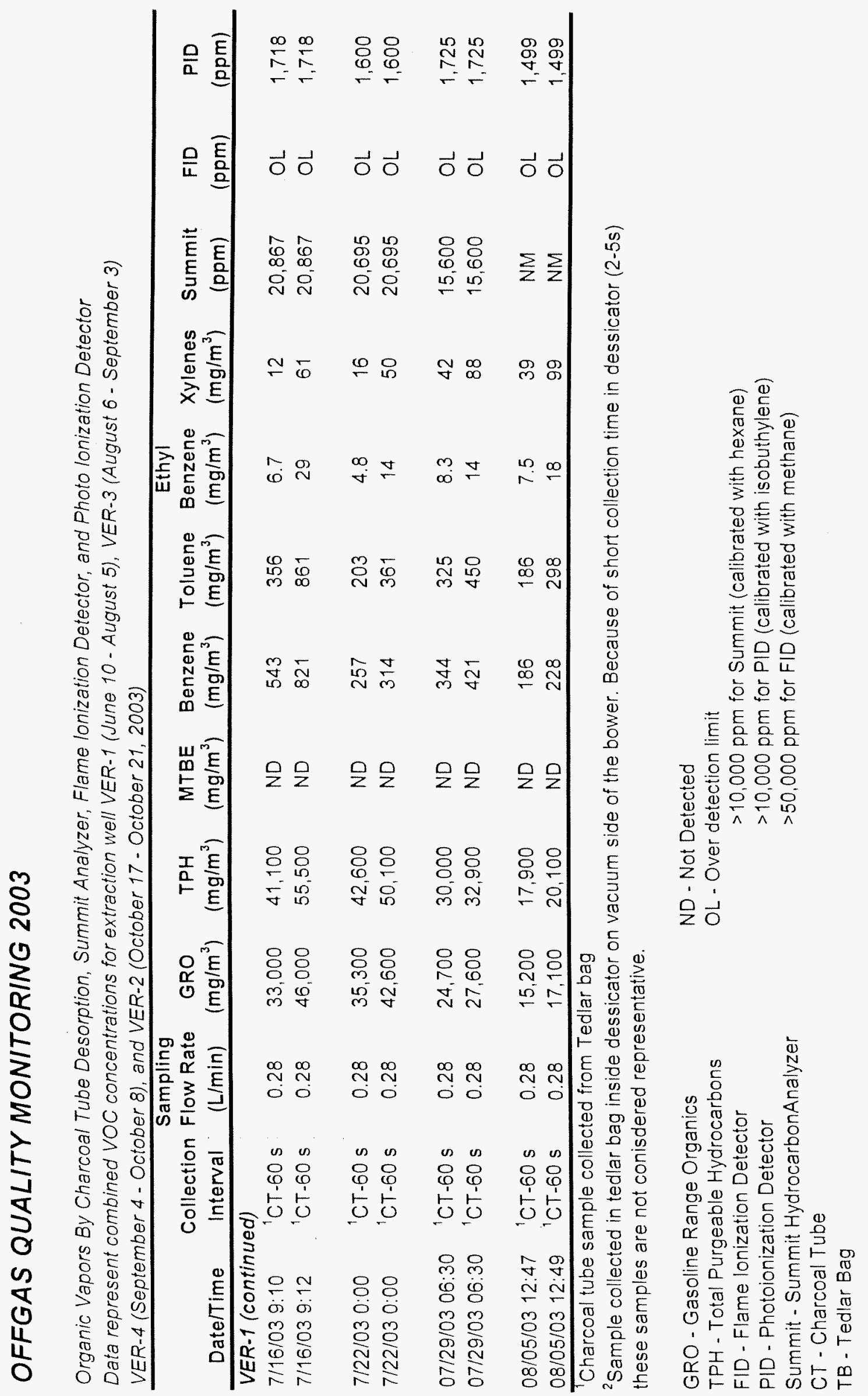

응 $\sum_{<}$

แ.

문

ㅇ

응으

E

के 


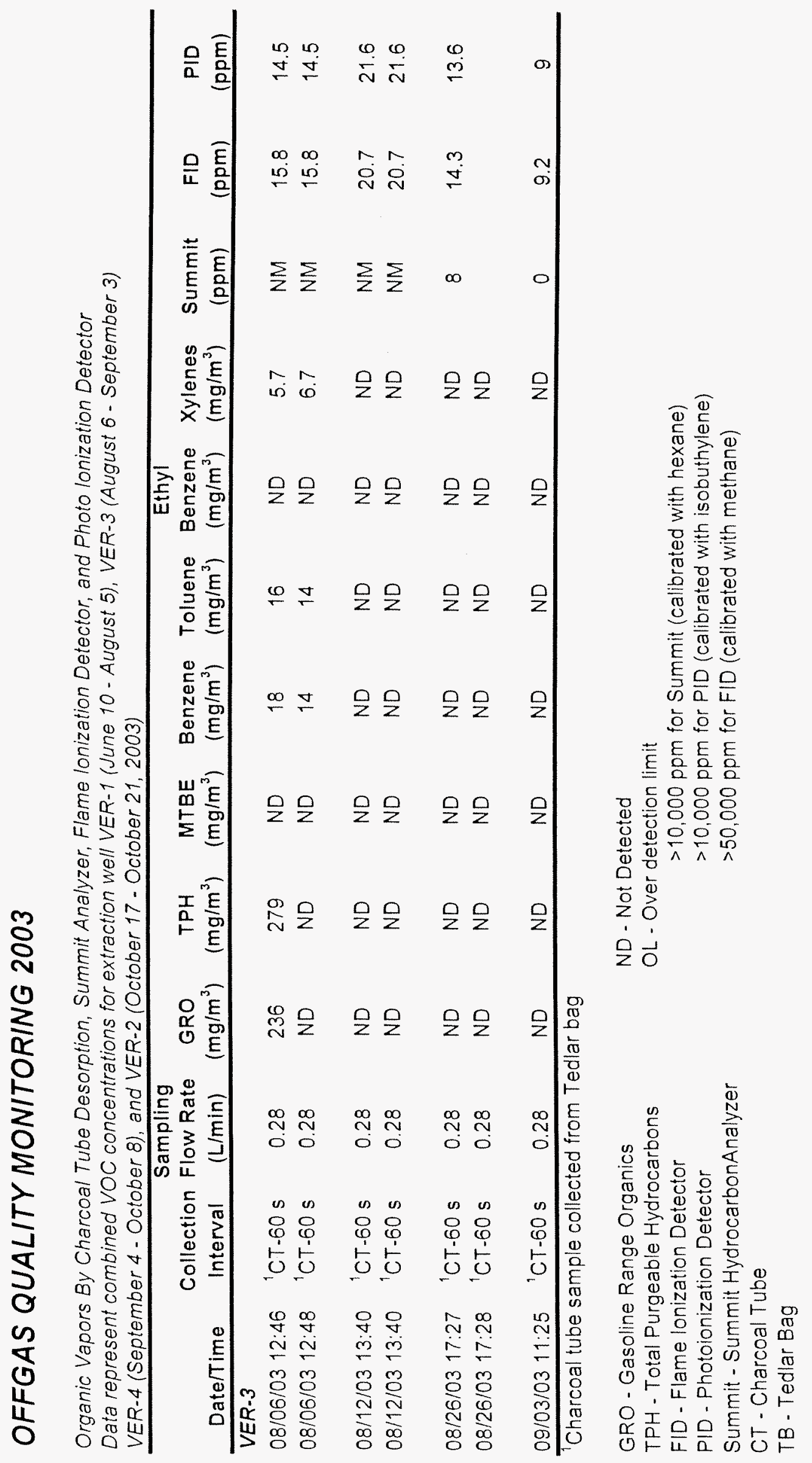

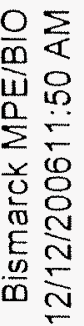




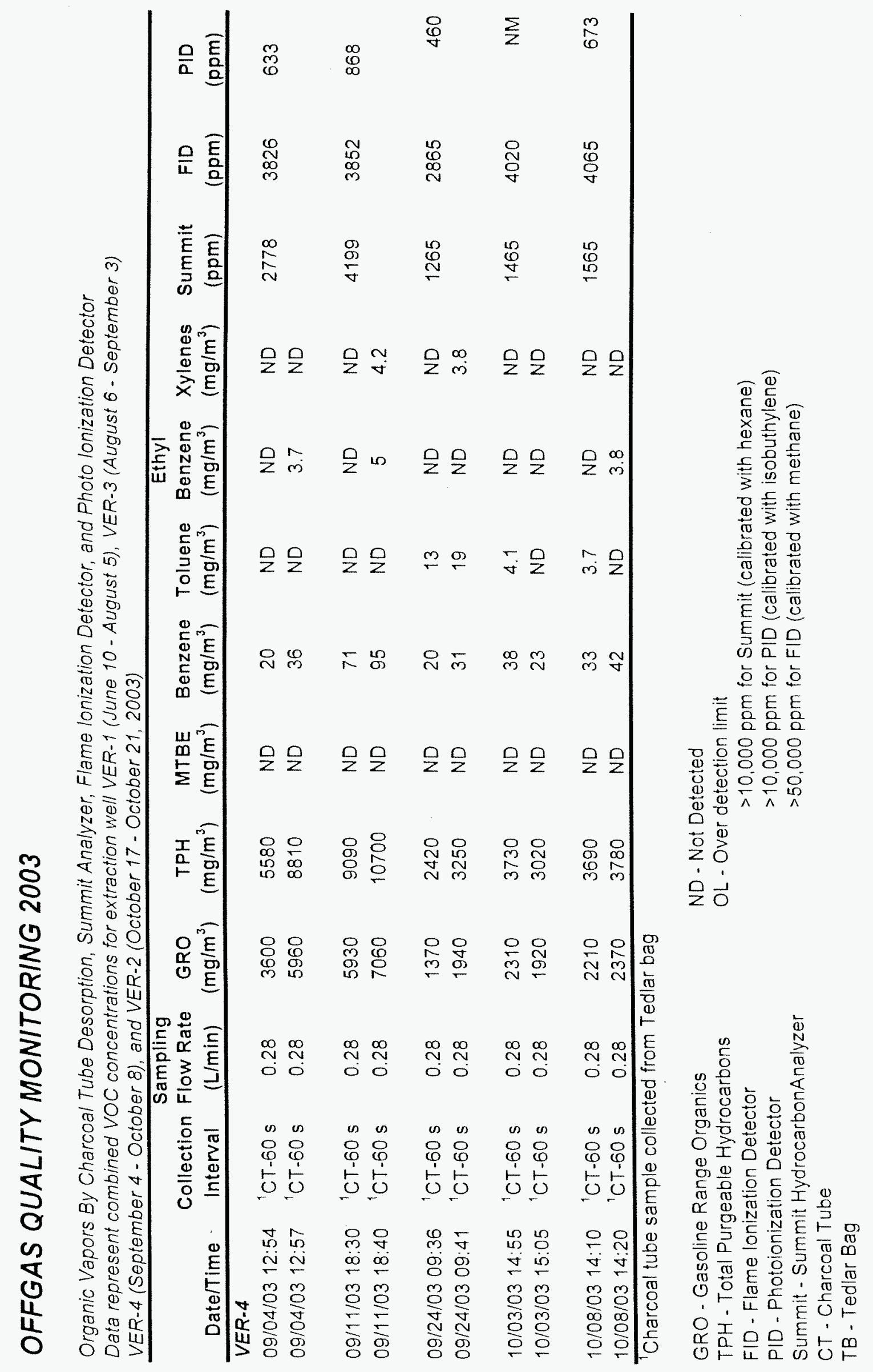

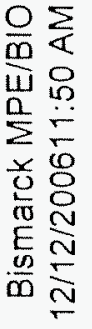




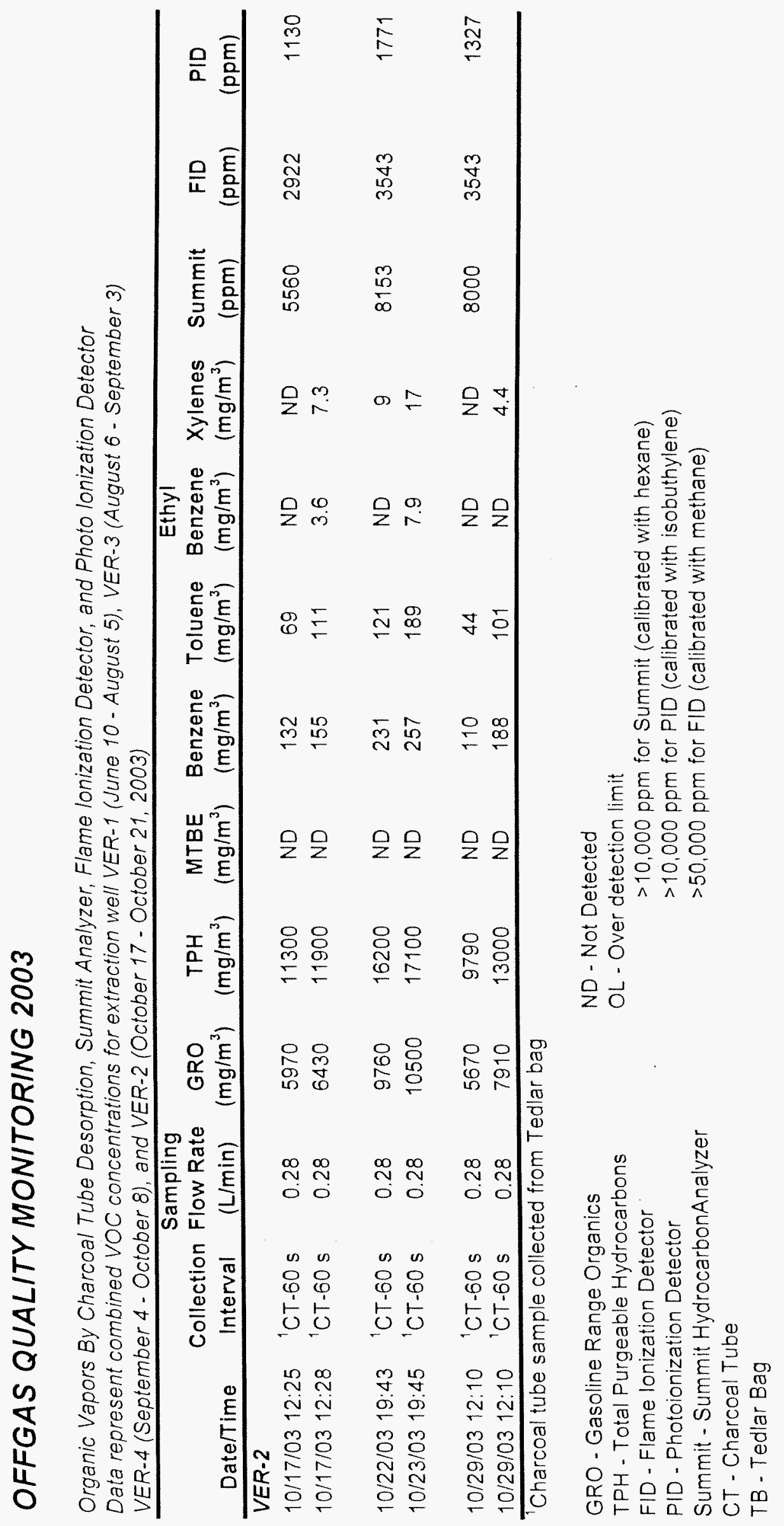

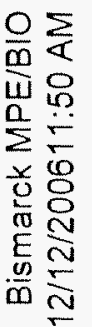


APPENDIX F

\section{COC ISOCONCENTRATION MAP}




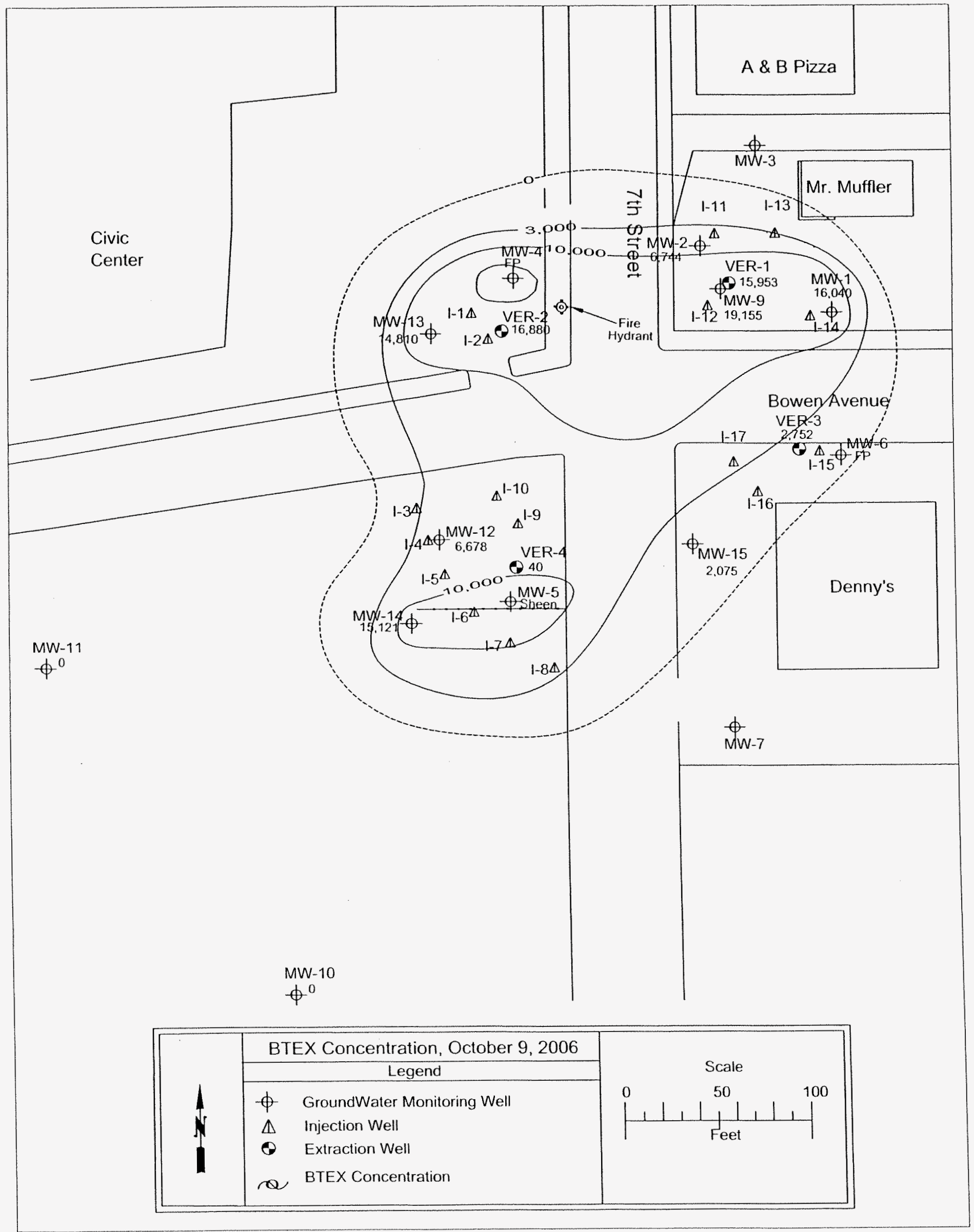




\section{APPENDIX G}

\section{GROUNDWATER QUALITY MONITORING - SUMMARY OF DATA}


APPENDIX G-1

COC IN GROUNDWATER 
GROUNDWATER QUALITY MONITORING

Extraction Wells

\begin{tabular}{|c|c|c|c|c|c|c|c|c|c|}
\hline Well ID & Date & $\begin{array}{l}\text { MTBE } \\
\mathrm{ppb}\end{array}$ & $\begin{array}{c}\text { Benzene } \\
\mathrm{ppb}\end{array}$ & $\begin{array}{c}\text { Toluene } \\
\text { ppb }\end{array}$ & $\begin{array}{c}\text { Ethylbenz. } \\
\text { ppb }\end{array}$ & $\begin{array}{l}\text { Xylenes } \\
\text { (total) ppb }\end{array}$ & $\begin{array}{c}\text { GRO (TPH) } \\
\mathrm{mg} / \mathrm{l}\end{array}$ & $\begin{array}{c}\text { BTEX } \\
\mathrm{mg} / 1\end{array}$ & $\begin{array}{l}\text { BTEX } \\
\text { Trend }\end{array}$ \\
\hline VER-1 & $06 / 10 / 03$ & $<1000$ & 14,600 & 9,960 & 2,550 & 11,450 & $<200$ & 38,560 & \\
\hline VER-1 & $11 / 19 / 03$ & $<200$ & 14,000 & 10,260 & 2,752 & 13,670 & 88.5 & 40,682 & \\
\hline VER-1 & $04 / 25 / 04$ & $<200$ & 13,890 & 10,410 & 2,842 & 13,800 & 88.5 & 40,942 & \\
\hline VER-1 & $10 / 23 / 04$ & $<200$ & 6,998 & 3,877 & 1,683 & 8,345 & 58.4 & 20,903 & 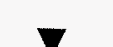 \\
\hline VER-1 & $05 / 17 / 05$ & 291 & 6,078 & 2,926 & 2,209 & 9,641 & 68.7 & 20,854 & $\nabla$ \\
\hline VER-1 & $11 / 19 / 05$ & $<200$ & 4,358 & 1,690 & 2,863 & 11,200 & 74.7 & 20,111 & \\
\hline VER-1 & $05 / 12 / 06$ & $<100$ & 3,619 & 796 & 2,747 & 10,160 & 56.7 & 17,322 & \\
\hline VER-1 & $10 / 10 / 06$ & $<100$ & 2,792 & 889 & 2,680 & 9,544 & 47.9 & 15,953 & \\
\hline VER-2 & $07 / 02 / 03$ & $<20$ & 4,000 & 2,890 & 518 & 1,630 & 19.4 & 9,038 & \multirow{8}{*}{$\boldsymbol{\Delta}$} \\
\hline VER-2 & $11 / 19 / 03$ & $<100$ & 4,642 & 7,813 & 1.419 & 7,760 & 67.3 & 21,634 & \\
\hline VER-2 & $04 / 25 / 04$ & \multicolumn{3}{|c|}{$0.04 \mathrm{ft}$ Free Product } & & & & 0 & \\
\hline VER-2 & $10 / 23 / 04$ & $<100$ & 2,089 & 2,178 & 144 & 5,525 & 43.1 & 9,936 & \\
\hline VER-2 & $05 / 17 / 05$ & 87.3 & 3,173 & 1,611 & 690 & 2,331 & 24.8 & 7,805 & \\
\hline VER-2 & $11 / 19 / 05$ & $<100$ & 5,399 & 4,319 & 943 & 3,937 & 32.3 & 14,598 & \\
\hline VER-2 & $05 / 12 / 06$ & $<50$ & 6,013 & 5,305 & 1.076 & 4,450 & 35.5 & 16,844 & \\
\hline VER-2 & $10 / 10 / 06$ & \multicolumn{2}{|c|}{$1.02 \mathrm{ft}$ Free Product } & & & & & & \\
\hline VER-3 & $07 / 02 / 03$ & $<20$ & 10,500 & 55 & 444 & 551 & $<60$ & 11,550 & \multirow{8}{*}{$\nabla$} \\
\hline VER-3 & $11 / 19 / 03$ & $<100$ & 5,039 & $<100$ & 117 & 336 & 10.8 & 5,492 & \\
\hline VER-3 & $04 / 25 / 04$ & $<25$ & 3,759 & $<25$ & 77 & 155 & 7.4 & 3,992 & \\
\hline VER-3 & $10 / 23 / 04$ & $<25$ & 2,931 & $<25$ & 85 & 141 & 8.4 & 3,157 & \\
\hline VER-3 & $05 / 17 / 05$ & 47 & 4,236 & 29 & 169 & 158 & 10.2 & 4,591 & \\
\hline VER-3 & $11 / 19 / 05$ & $<50$ & 4,946 & 61 & 293 & 241 & 11.6 & 5,541 & \\
\hline VER-3 & $05 / 12 / 06$ & $<20$ & 4,637 & 27 & 264 & 92 & 9.3 & 5,020 & \\
\hline VER-3 & $10 / 10 / 06$ & $<20$ & 2.491 & $<20$ & 261 & $<60$ & 7.0 & 2,752 & \\
\hline VER-4 & $07 / 02 / 03$ & 227 & 4,530 & 141 & 250 & 486 & 9.4 & 5,407 & \multirow{8}{*}{$\boldsymbol{\nabla}$} \\
\hline VER-4 & $11 / 19 / 03$ & $<200$ & 10,320 & 281 & 857 & 2,048 & 27.3 & 13,507 & \\
\hline VER-4 & $04 / 25 / 04$ & $<200$ & 7,960 & $<200$ & 465 & 756 & 24.3 & 9,181 & \\
\hline VER-4 & $10 / 23 / 04$ & $<50$ & 6.483 & 76 & $<50$ & 699 & 14.4 & 7,258 & \\
\hline VER-4 & $05 / 17 / 05$ & 55.1 & 4,909 & $<50$ & 264 & 280 & 12.7 & 5,452 & \\
\hline VER-4 & $11 / 19 / 05$ & $<100$ & 11,080 & 141 & 1,466 & 1,385 & 30.4 & 14,072 & \\
\hline VER-4 & $05 / 12 / 06$ & $<50$ & 5,553 & $<50$ & 745.2 & 384.8 & 15.92 & 6,683 & \\
\hline VER-4 & $10 / 10 / 06$ & $<1$ & 33 & $<1$ & $<1$ & 7.5 & 0.65 & 40 & \\
\hline
\end{tabular}


GROUNDWATER QUALITY MONITORING

Monitoring Wells

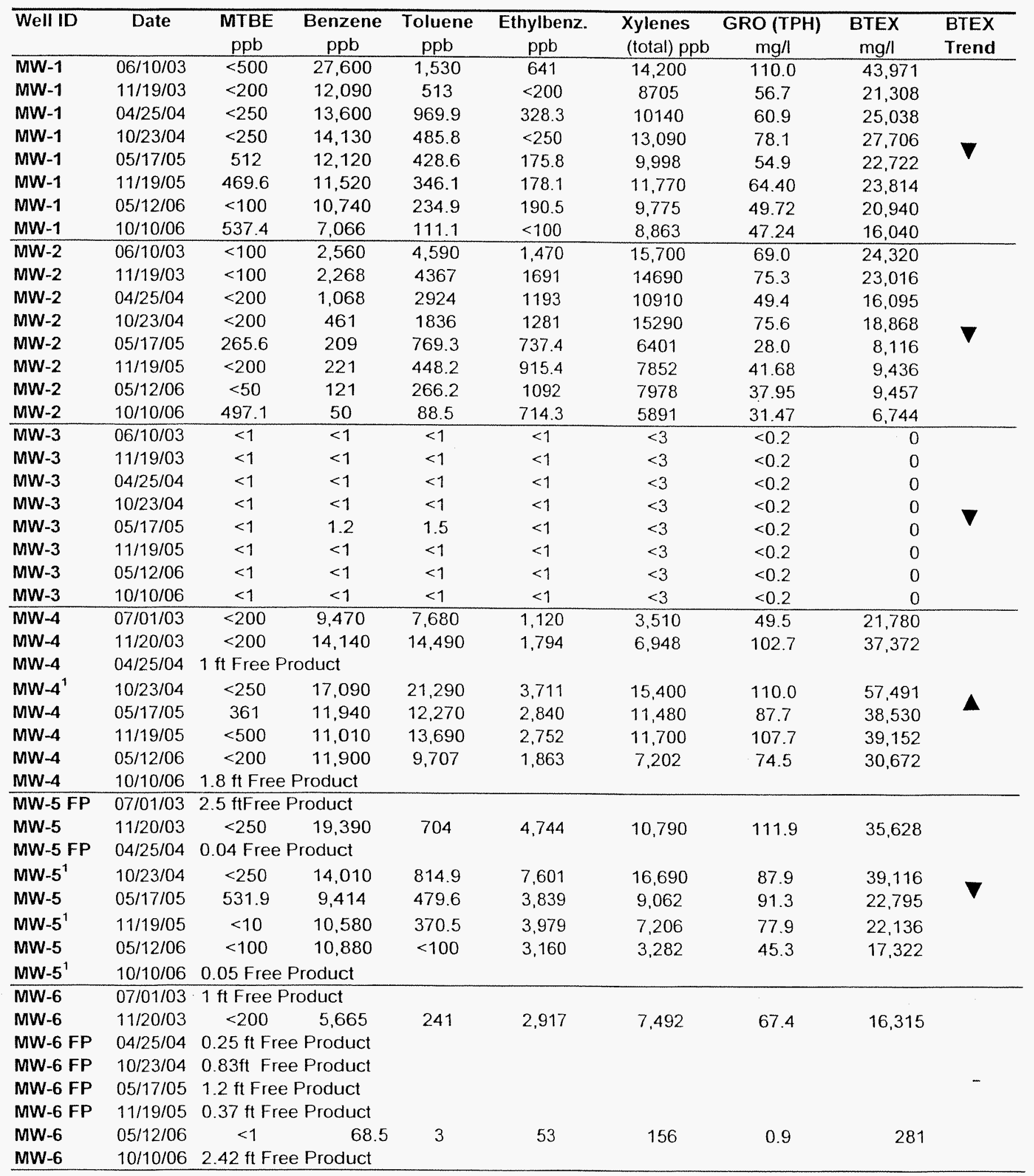


GROUNDWATER QUALITY MONITORING

Monitoring Wells (continued)

\begin{tabular}{|c|c|c|c|c|c|c|c|c|c|}
\hline Well ID & Date & $\begin{array}{c}\text { MTBE } \\
\mathrm{ppb}\end{array}$ & $\begin{array}{c}\text { Benzene } \\
\mathrm{ppb}\end{array}$ & $\begin{array}{c}\text { Toluene } \\
\mathrm{ppb}\end{array}$ & $\begin{array}{c}\text { Ethylbenz. } \\
\text { ppb }\end{array}$ & $\begin{array}{l}\text { Xylenes } \\
\text { (total) ppb }\end{array}$ & $\begin{array}{c}\text { GRO (TPH) } \\
\mathrm{mg} / 1\end{array}$ & $\begin{array}{c}\text { BTEX } \\
\mathrm{mg} / 1\end{array}$ & $\begin{array}{l}\text { BTEX } \\
\text { Trend }\end{array}$ \\
\hline$\overline{M W-7}$ & $07 / 01 / 03$ & $<1$ & $<1$ & $<1$ & $<1$ & $<3$ & $<0.2$ & 0 & \\
\hline$M W-7$ & $11 / 20 / 03$ & $<1$ & $<1$ & $<1$ & $<1$ & $<3$ & $<0.2$ & 0 & \\
\hline$M W-7$ & $04 / 25 / 04$ & $<1$ & 7.2 & 3.3 & 14.0 & 77.7 & 0.2 & 102 & - \\
\hline MW-7 & $10 / 23 / 04$ & $<1$ & $<1$ & $<1$ & $<1$ & $<3$ & $<0.2$ & 0 & \\
\hline MW-7 & $05 / 17 / 05$ & $<1$ & $<1$ & $<1$ & $<1$ & $<3$ & $<0.2$ & 0 & \\
\hline MW-9 & $06 / 10 / 03$ & $<100$ & 42,900 & 17,600 & 2,730 & 8,910 & 121.0 & 72,140 & \\
\hline MW-9 & $11 / 19 / 03$ & $<500$ & 22,370 & 14,460 & 2,910 & 10,950 & 79.4 & 50,690 & \\
\hline MW-9 & $04 / 25 / 04$ & $<250$ & 14,340 & 8,630 & 2,241 & 8,388 & 60.2 & 33,599 & \\
\hline MW-9 & $10 / 23 / 04$ & $<250$ & 12,710 & 2,046 & 1,368 & 4,569 & 57.7 & 20,693 & 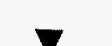 \\
\hline MW-9 & $05 / 17 / 05$ & 81.9 & 7,854 & 1,998 & 1.759 & 5.775 & 29.6 & 17,386 & $\nabla$ \\
\hline MW-9 & $11 / 19 / 05$ & $<500$ & 9,904 & 2,863 & 3,197 & 10,850 & 61.6 & 26,814 & \\
\hline MW-9 & 05/12/06 & $<100$ & 7,359 & 2,103 & 2,610 & 8,117 & 51.4 & 20,189 & \\
\hline MW-9 & $10 / 10 / 06$ & 553.4 & 6,643 & 2,235 & 2,705 & 7,572 & 54.7 & 19,155 & \\
\hline$M W-10$ & $07 / 01 / 03$ & $<1$ & $<1$ & $<1$ & $<1$ & $<3$ & $<0.2$ & 0 & \\
\hline MW-10 & $11 / 20 / 03$ & $<1$ & $<1$ & $<1$ & $<1$ & $<3$ & $<0.2$ & 0 & \\
\hline MW-10 & $04 / 25 / 04$ & $<1$ & $<1$ & $<1$ & $<1$ & $<3$ & $<0.2$ & 0 & \\
\hline MW-10 & $10 / 23 / 04$ & $<1$ & $<1$ & $<1$ & $<1$ & $<3$ & $<0.2$ & 0 & \\
\hline MW-10 & $05 / 17 / 05$ & $<1$ & 3 & 2 & 2 & 5 & $<0.2$ & 12 & - \\
\hline MW-10 & $11 / 19 / 05$ & $<1$ & $<1$ & $<1$ & $<1$ & $<3$ & $<0.2$ & 0 & \\
\hline MW-10 & $05 / 12 / 06$ & $<1$ & $<1$ & $<1$ & $<1$ & $<3$ & $<0.2$ & 0 & \\
\hline MW-10 & $10 / 10 / 06$ & $<1$ & $<1$ & $<1$ & $<1$ & $<3$ & $<0.2$ & 0 & \\
\hline MW-11 & $07 / 01 / 03$ & $<1$ & $<1$ & $<1$ & $<1$ & $<3$ & $<0.2$ & 0 & \\
\hline MW-11 & $11 / 20 / 03$ & $<1$ & $<1$ & $<1$ & $<1$ & $<3$ & $<0.2$ & 0 & \\
\hline MW-11 & $04 / 25 / 04$ & $<1$ & $<1$ & $<1$ & $<1$ & $<3$ & $<0.2$ & 0 & \\
\hline MW-11 & $10 / 23 / 04$ & $<1$ & $<1$ & $<1$ & $<1$ & $<3$ & $<0.2$ & 0 & \\
\hline MW-11 & $05 / 17 / 05$ & $<1$ & 1 & $<1$ & $<1$ & $<3$ & $<0.2$ & 1 & - \\
\hline MW-11 & $11 / 19 / 05$ & $<1$ & $<1$ & $<1$ & $<1$ & $<3$ & $<0.2$ & 0 & \\
\hline MW-11 & $05 / 12 / 06$ & $<1$ & $<1$ & $<1$ & $<1$ & $<3$ & $<0.2$ & 0 & \\
\hline MW-11 & $10 / 10 / 06$ & $<1$ & $<1$ & $<1$ & $<1$ & $<3$ & $<0.2$ & 0 & \\
\hline MW-12 & $07 / 01 / 03$ & $<10$ & 1,380 & $<10$ & 131 & 116 & 3.67 & 1,627 & \\
\hline MW-12 & $11 / 20 / 03$ & $<10$ & 786 & 10.7 & 79.2 & 99.7 & 4.2 & 976 & \\
\hline MW-12 & $04 / 25 / 04$ & $<20$ & 1,504 & $<20$ & 112 & 141.2 & 5.7 & 1,757 & \\
\hline MW-12 & $10 / 23 / 04$ & $<5$ & 618 & $<5$ & $<5$ & $<15$ & 1.2 & 618 & 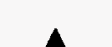 \\
\hline MW-12 & $05 / 17 / 05$ & $<10$ & 1,052 & $<10$ & 15.8 & $<30$ & 2.3 & 1,068 & $\mathbf{A}$ \\
\hline MW-12 & $11 / 19 / 05$ & $<20$ & 1,794 & $<20$ & $<20$ & $<60$ & 4.5 & 1,794 & \\
\hline MW-12 & 05/12/06 & $<1$ & 1,992 & $<1$ & $<1$ & $<3$ & 3.5 & 1,992 & \\
\hline MW-12 & $10 / 10 / 06$ & 71 & 6,636 & 5.4 & 16.3 & 20.1 & 15.5 & 6,678 & \\
\hline MW-13 & $07 / 01 / 03$ & $<50$ & 5,220 & 5740 & 974 & 3,160 & 34.5 & 15,094 & \\
\hline MW-13 & $11 / 20 / 03$ & $<100$ & 7,270 & 6064 & 991 & 3341 & 48.7 & 17,666 & \\
\hline MW-13 & $04 / 25 / 04$ & $<100$ & 9,981 & 3503 & 1352 & 2564 & 39.9 & 17,400 & \\
\hline MW-13 & $10 / 23 / 04$ & $<100$ & 5,733 & 4791 & $<100$ & 4256 & 51.2 & 14,780 & \\
\hline$M W-13$ & $05 / 17 / 05$ & $<200$ & 8,978 & 5567 & 1112 & 2911 & 51.9 & 18,568 & \\
\hline MW-13 & $11 / 19 / 05$ & $<200$ & 9,455 & 6594 & 1329 & 3681 & 50.1 & 21,059 & \\
\hline MW-13 & $05 / 12 / 06$ & $<100$ & 5,784 & 2446 & 960.3 & 1699 & 25.9 & 10,889 & \\
\hline MW-13 & $10 / 10 / 06$ & $<20$ & 8,324 & 3445 & 1137 & 1904 & 36.3 & 14,810 & \\
\hline$\overline{M W-14}$ & $07 / 01 / 03$ & $<250$ & 19,800 & $<250$ & 1010 & 1,340 & $<50$ & 22,150 & \\
\hline MW-14 & $11 / 20 / 03$ & $<200$ & 16,740 & 277.8 & 204 & 1950 & 52.4 & 19.172 & \\
\hline MW-14 & $04 / 25 / 04$ & $<20$ & 11,170 & 106.7 & 1128 & 1195 & 22.9 & 13,600 & \\
\hline MW-14 & $10 / 23 / 04$ & $<20$ & 11,450 & 151.4 & 1429 & 1266 & 25.6 & 14,296 & \\
\hline MW-14 & $05 / 17 / 05$ & $<200$ & 12,130 & 262.5 & 1294 & 965.3 & 40.8 & 14,652 & \\
\hline MW-14 & $11 / 19 / 05$ & $<200$ & 13,520 & 243.6 & 1762 & 1092 & 36.9 & 16,618 & \\
\hline MW-14 & 05/12/06 & $<100$ & 11,670 & 114.1 & 1726 & 961.7 & 30.1 & 14,472 & \\
\hline MW-14 & $10 / 10 / 06$ & 262 & 11,720 & $<100$ & 2134 & 1267 & 36.1 & 15,121 & \\
\hline
\end{tabular}


GROUNDWATER QUALITY MONITORING

Monitoring Wells (continued)

\begin{tabular}{|c|c|c|c|c|c|c|c|c|c|}
\hline Well ID & Date & $\begin{array}{c}\text { MTBE } \\
\text { ppb }\end{array}$ & $\begin{array}{c}\text { Benzene } \\
\text { ppb }\end{array}$ & $\begin{array}{c}\text { Toluene } \\
\text { ppb }\end{array}$ & $\begin{array}{c}\text { Ethylbenz. } \\
\text { ppb }\end{array}$ & $\begin{array}{l}\text { Xylenes } \\
\text { (total) ppb }\end{array}$ & $\begin{array}{c}\text { GRO (TPH) } \\
\mathrm{mg} / \mathrm{l}\end{array}$ & $\begin{array}{c}\text { BTEX } \\
\mathrm{mg} /\end{array}$ & $\begin{array}{l}\text { BTEX } \\
\text { Trend }\end{array}$ \\
\hline MW-15 & $07 / 01 / 03$ & $<100$ & 7,410 & $<100$ & 380 & 2,710 & 26.2 & 10,500 & \\
\hline MW-15 & $11 / 20 / 03$ & $<100$ & 6,000 & $<100$ & 470 & 2283 & 28.9 & 8,753 & \\
\hline$M W-15$ & $04 / 25 / 04$ & $<25$ & 3,627 & $<25$ & 259.4 & 731.4 & 13.6 & 4,618 & \\
\hline$M W-15$ & $10 / 23 / 04$ & $<25$ & 3,103 & $<25$ & 210.2 & 707.6 & 12.1 & 4,021 & \\
\hline MW-15 & $05 / 17 / 05$ & 73 & 1,921 & $<50$ & 293.2 & 739.9 & $<10$ & 2,954 & \\
\hline$M W-15$ & $11 / 19 / 05$ & $<50$ & 2,808 & $<50$ & 439.2 & 986.6 & 11.7 & 4,234 & \\
\hline$M W-15$ & $05 / 12 / 06$ & $<10$ & 2,358 & 13 & 430.2 & 880.8 & 10.6 & 3,682 & \\
\hline MW-15 & $10 / 10 / 06$ & $<10$ & 1,412 & $<10$ & 291.6 & 370.9 & 7.5 & 2,075 & \\
\hline
\end{tabular}

${ }^{1} \mathrm{FP}$ sheen

GROUNDWATER QUALITY MONITORING

Injection Wells

\begin{tabular}{lccccccc}
\hline Well ID & Date & $\begin{array}{c}\text { MTBE } \\
\mathrm{ppb}\end{array}$ & $\begin{array}{c}\text { Benzene } \\
\mathrm{ppb}\end{array}$ & $\begin{array}{c}\text { Toluene } \\
\mathrm{ppb}\end{array}$ & $\begin{array}{c}\text { Ethylbenz. } \\
\mathrm{ppb}\end{array}$ & $\begin{array}{c}\text { Xylenes } \\
\text { (total) ppb }\end{array}$ & $\begin{array}{c}\text { GRO (TPH) } \\
\text { mg/l }\end{array}$ \\
\hline I-1 & $07 / 02 / 03$ & $<20$ & 1,550 & 2,010 & 224 & 935 & 9.42 \\
I-2 & $07 / 02 / 03$ & $<20$ & 2,370 & 2,590 & 302 & 1,260 & 12.9 \\
I-3 & $07 / 02 / 03$ & $<10$ & 2,020 & 101 & 322 & 921 & 8.1 \\
I-4 & $07 / 02 / 03$ & $<1$ & 1,100 & 6.9 & 66.5 & 253 & 3.35 \\
I-5 & $07 / 02 / 03$ & $<10$ & 985 & 17.7 & 87.1 & 119 & 2.78 \\
I-6 & $07 / 02 / 03$ & $<10$ & 11,900 & 109 & 916 & 864 & 28.7 \\
I-7 & $07 / 02 / 03$ & $<5$ & 4,770 & 61.8 & 597 & 368 & 12.6 \\
I-8 & $07 / 02 / 03$ & $<20$ & 5,460 & 179 & 2270 & 2,920 & 27.8 \\
I-8 & $11 / 19 / 03$ & $<1$ & 70.4 & 2.9 & 1 & 8.9 & 0.89 \\
I-8 & $04 / 25 / 04$ & $<1$ & 104.8 & 4.8 & 46.1 & 126 & 2.389 \\
I-8 & $05 / 17 / 05$ & 6.7 & 16.1 & $<1$ & $<1$ & $<3$ & 0.25 \\
I-8 & $10 / 10 / 06$ & 19 & 95.9 & $<1$ & $<1$ & 4.1 & 0.896 \\
I-9 & $07 / 02 / 03$ & 254 & 1,340 & 11.4 & 58.7 & 178 & 3.52 \\
I-10 & $07 / 02 / 03$ & 121 & 480 & 21.8 & 56.1 & 206 & 1.89 \\
I-11 & $06 / 10 / 03$ & $<50$ & 1,790 & 141 & 69.5 & 7,360 & 30.8 \\
I-12 & $06 / 10 / 03$ & $<200$ & 38,500 & 10,900 & 1590 & 7.220 & 103.0 \\
I-13 & $06 / 10 / 03$ & $<10$ & 969 & 27.4 & 190 & 653 & 13.1 \\
I-14 & $06 / 10 / 03$ & $<500$ & 36,500 & 1,960 & 2090 & 3,470 & 100.0 \\
I-15 & $07 / 02 / 03$ & $<10$ & 4,710 & 24.5 & 54.5 & 202 & $<20$ \\
I-16 & $07 / 02 / 03$ & $<10$ & 7,810 & 86.8 & 987 & 573 & $<40$ \\
I-17 & $07 / 02 / 03$ & $<20$ & 9,360 & 87.2 & 952 & 2,040 & $<50$ \\
\hline
\end{tabular}


APPENDIX G-2

\section{BIODEGRADATION INDICATORS}




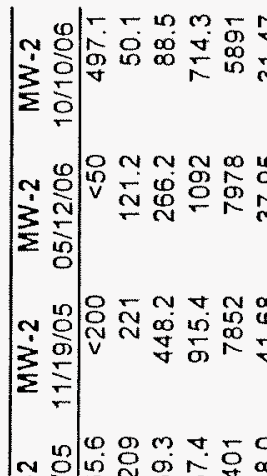

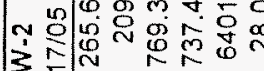

$\sum \frac{\pi}{5}$

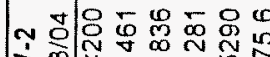

市 $\stackrel{m}{\mathrm{~N}}$

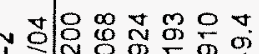

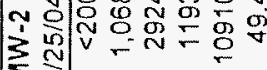

$\Sigma$ 列

ษ

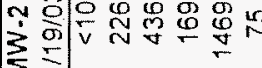

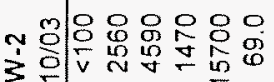

웧

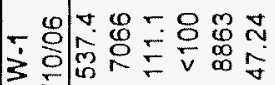

$\sum \frac{0}{5}$

colo o m in $\mathrm{x}$

उ

$\sum \frac{\pi}{5}$

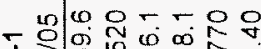

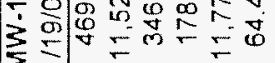

$\sum$

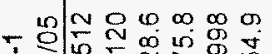

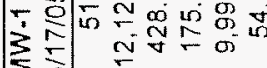

产

告

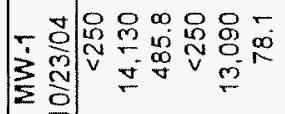

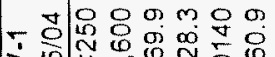

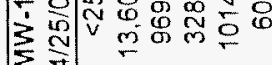

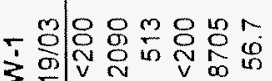

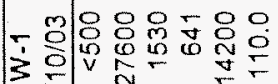

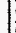

$\sum$ 熍

응응명응응

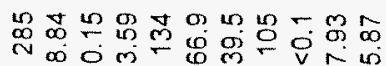

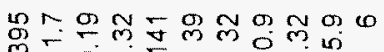

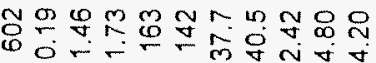

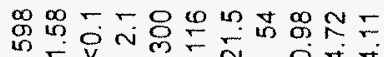

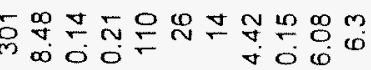

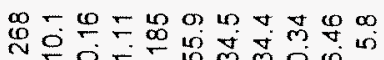

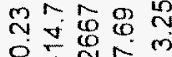

$0 \div \underset{0}{0}$

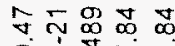

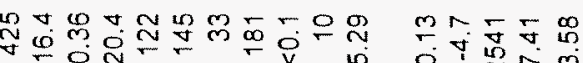

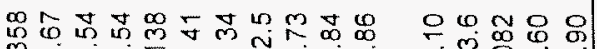

-OO $\stackrel{\sim}{\sim}$

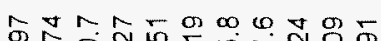

कि

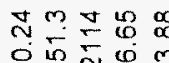

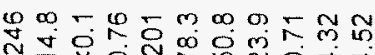

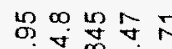

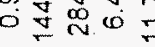

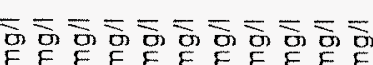

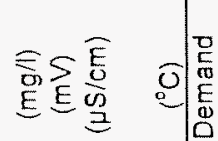

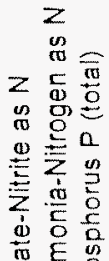

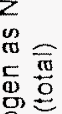

选高

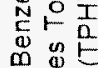

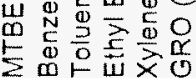

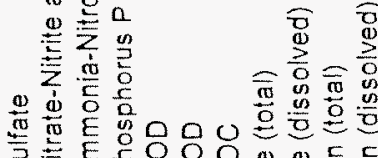

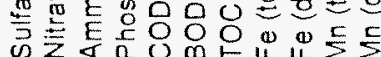

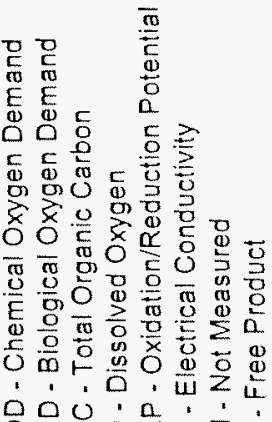

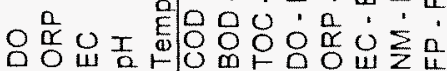




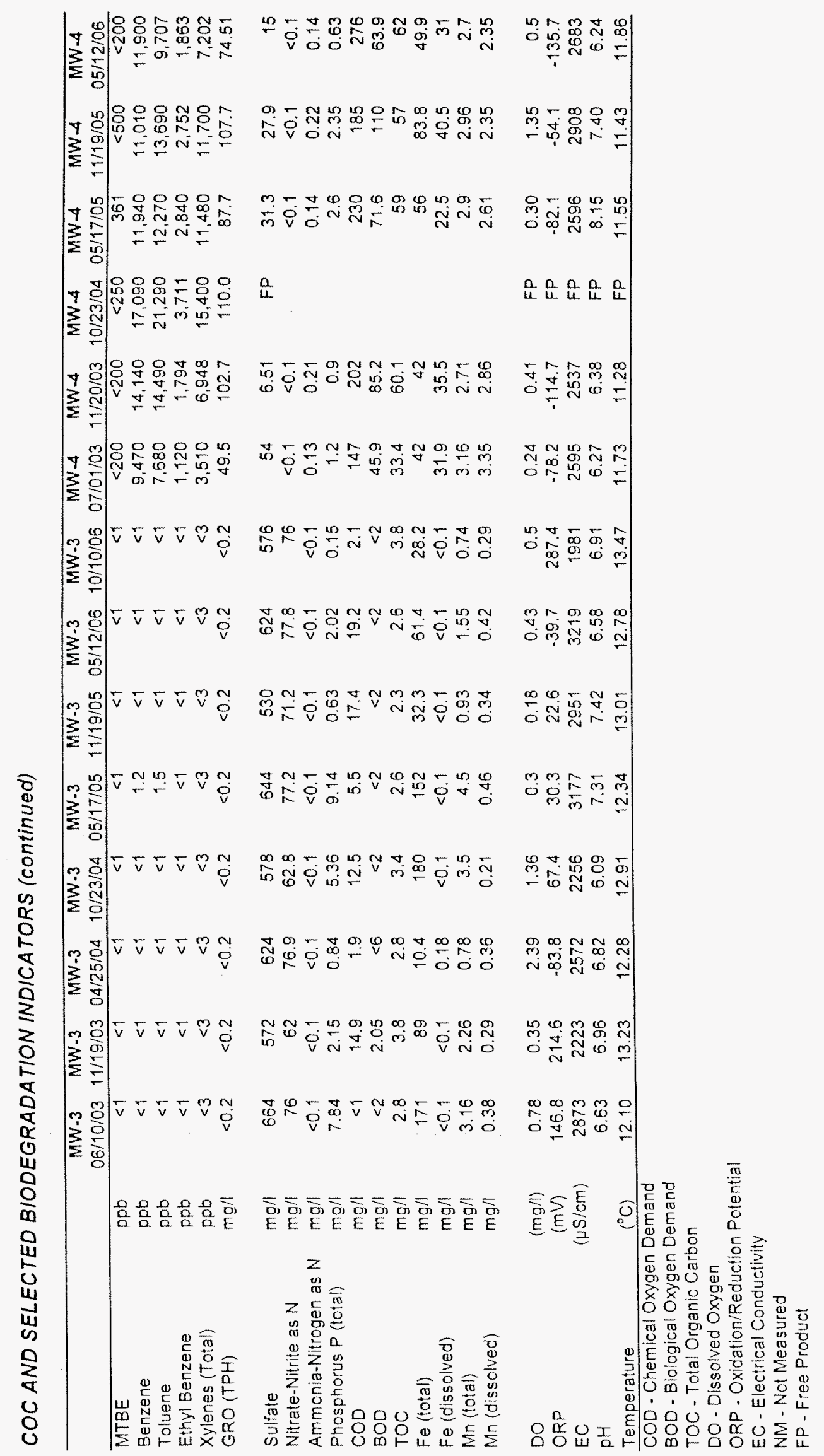




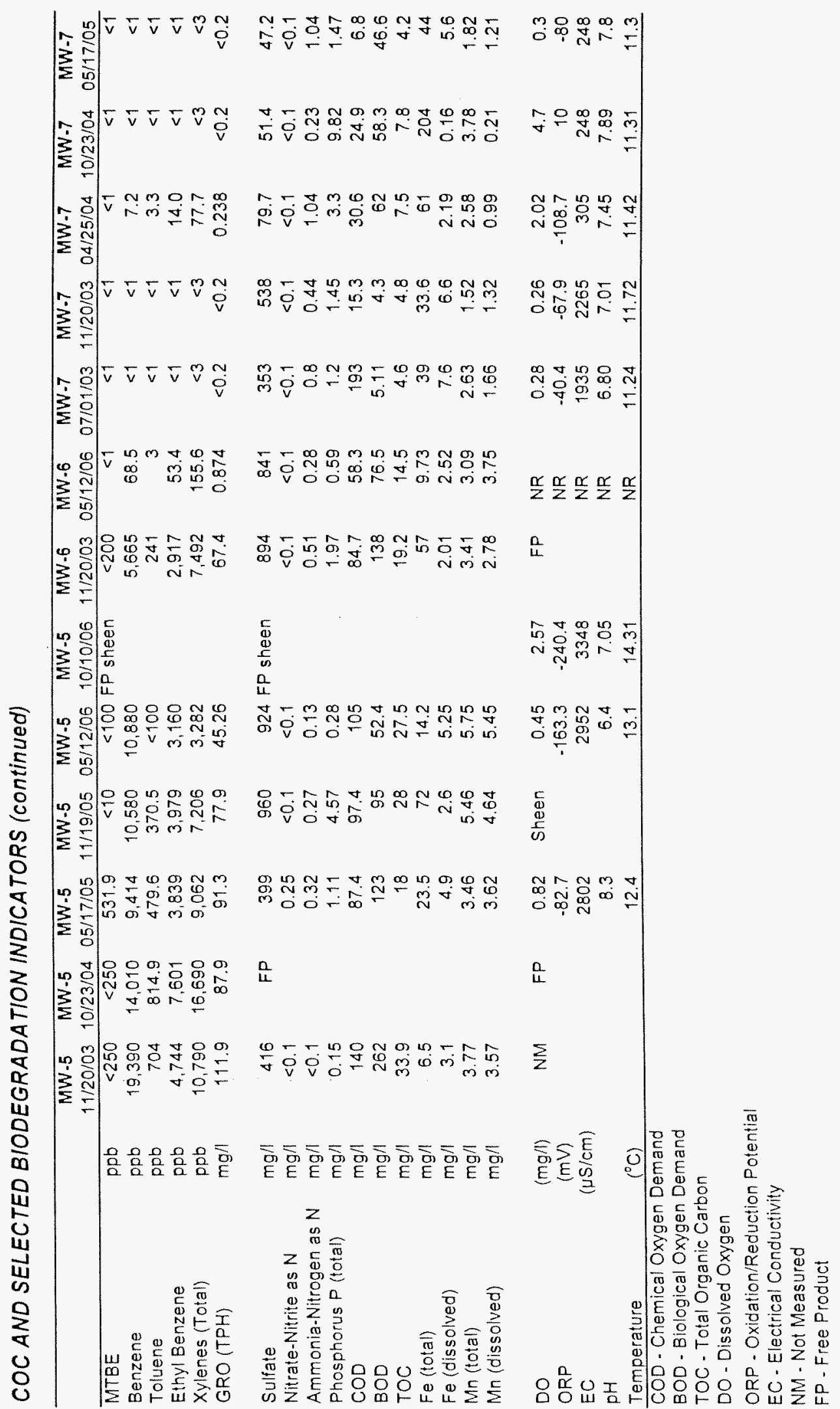




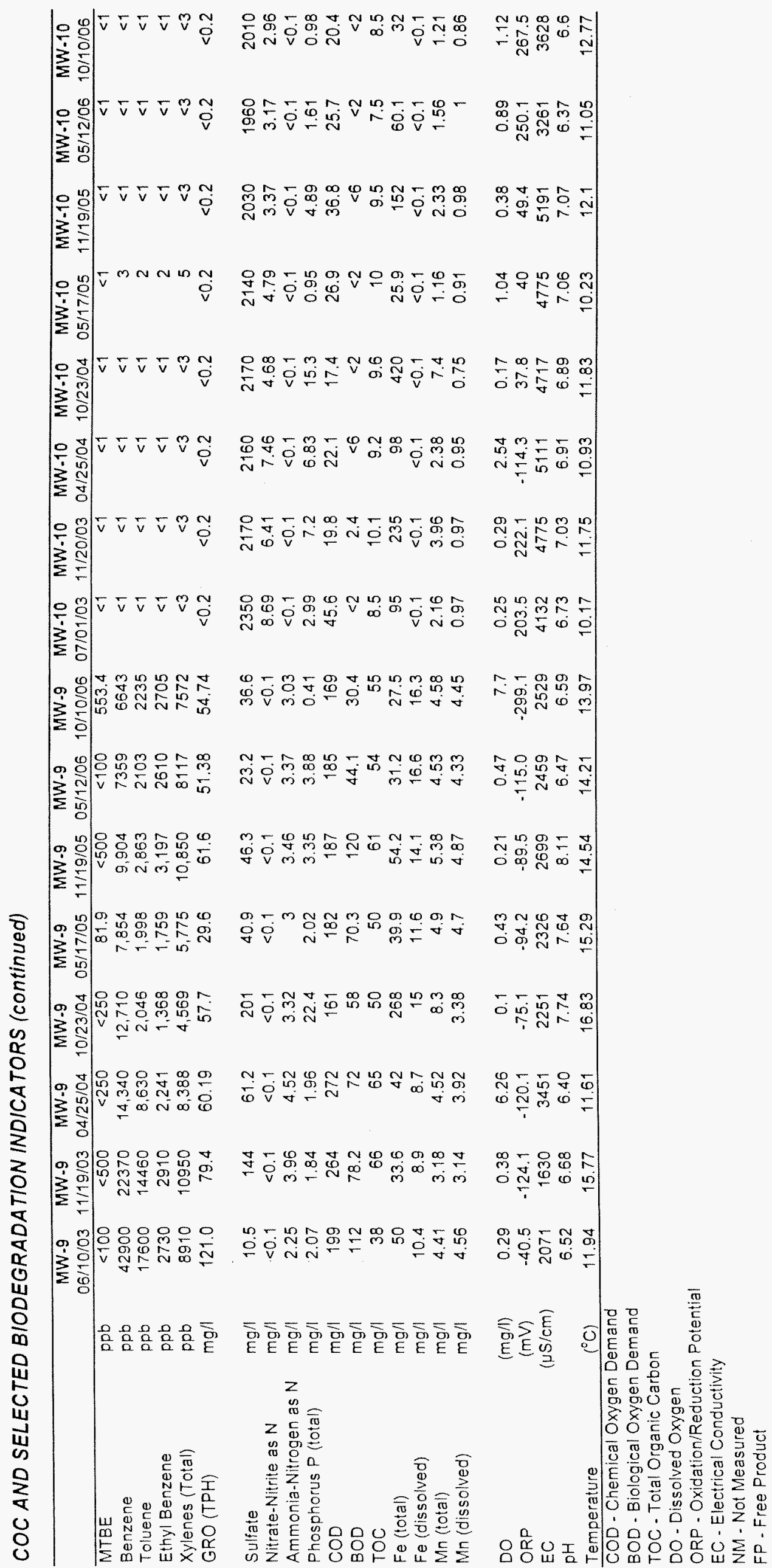




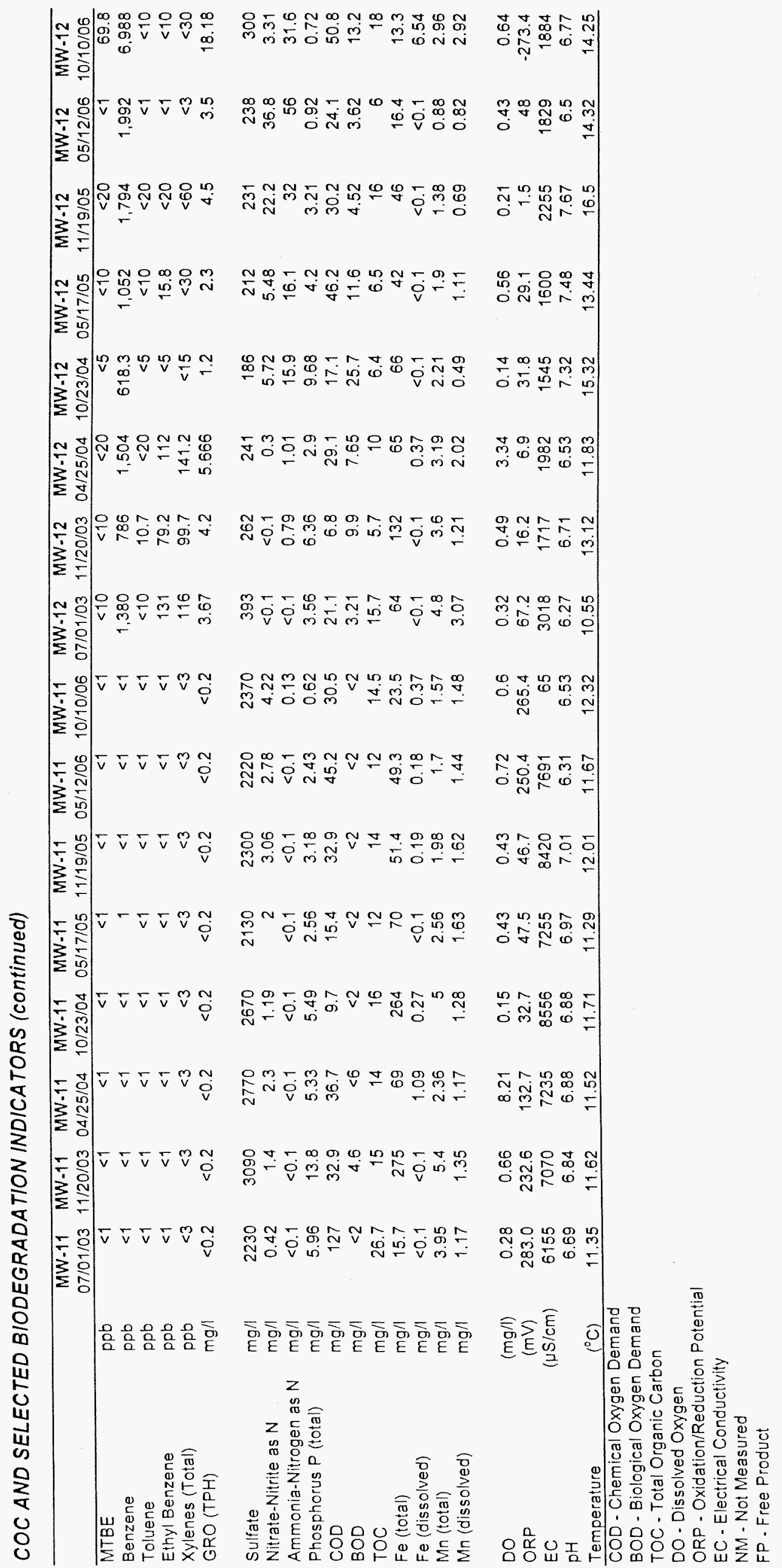




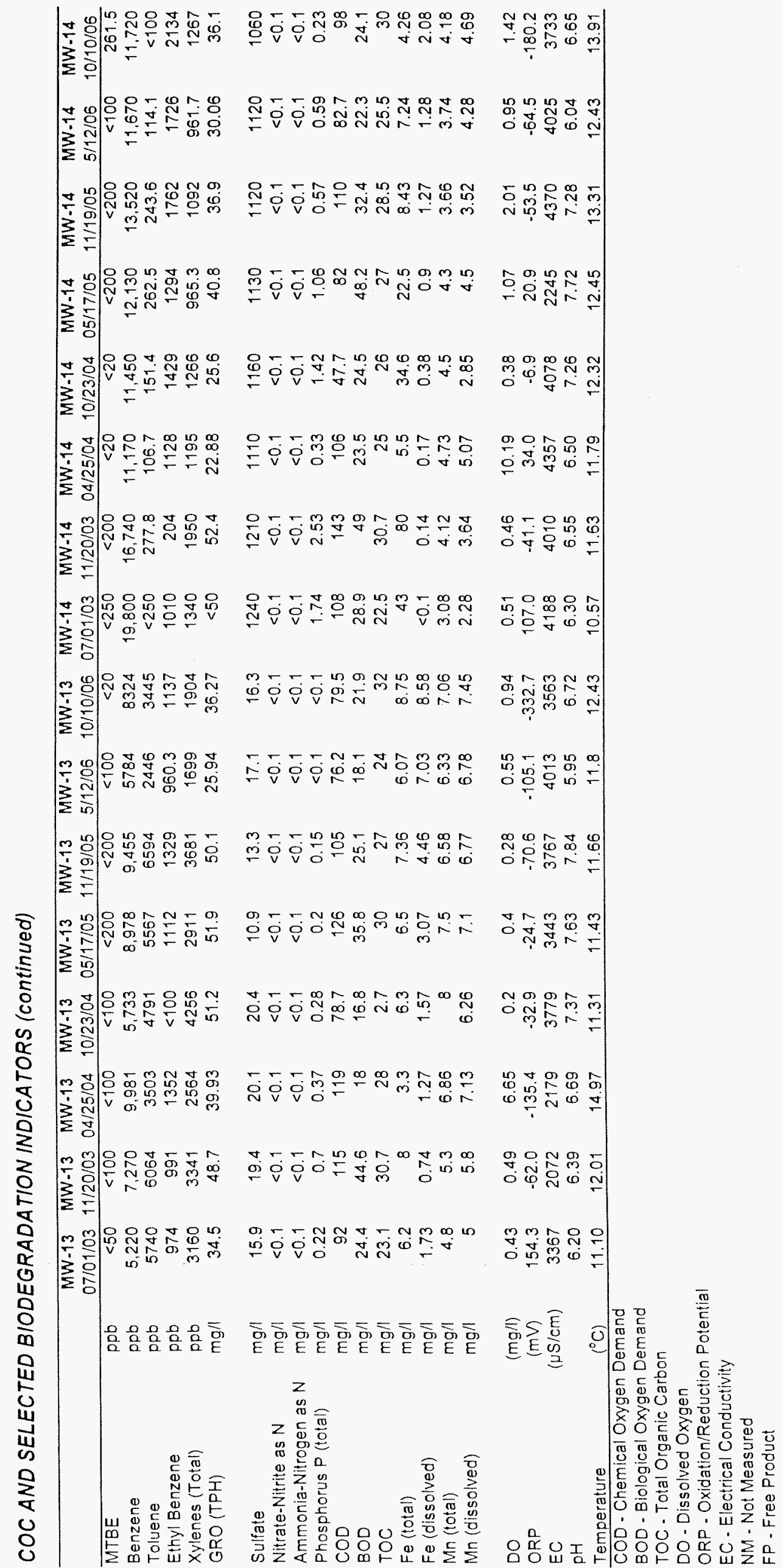




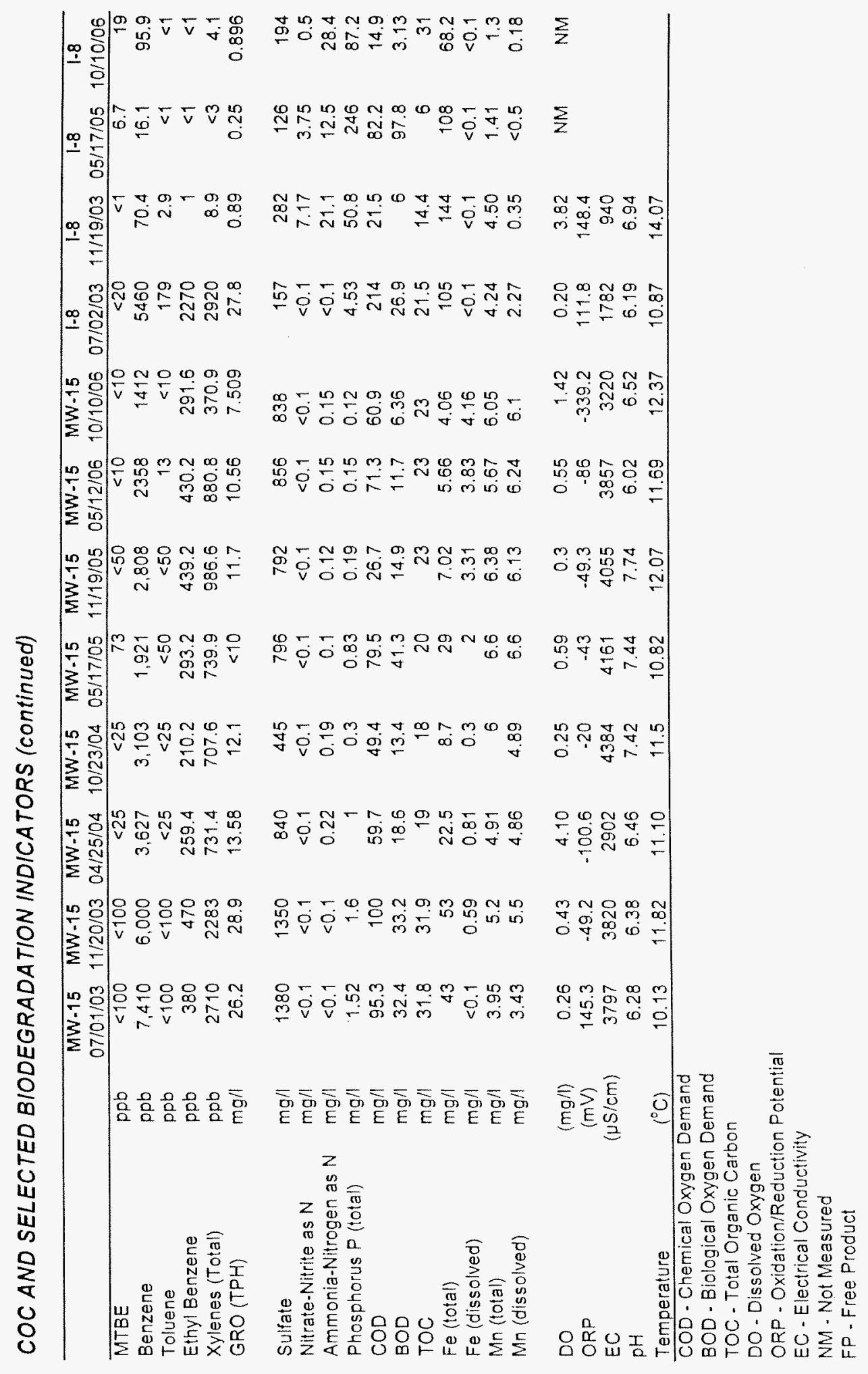




\begin{tabular}{|c|c|c|c|c|c|}
\hline Well ID & Date & $\begin{array}{c}\text { Nitrate-Nitrite as } \mathrm{N} \\
\mathrm{mg} / \mathrm{l}\end{array}$ & Well ID & Date & $\begin{array}{c}\text { Nitrate-Nitrite as } \mathbf{N} \\
\mathrm{mg} / \mathrm{l}\end{array}$ \\
\hline I-1 & $07 / 02 / 03$ & 20.8 & $1-9$ & $07 / 02 / 03$ & 4.42 \\
\hline 1-1 & $04 / 24 / 04$ & 5.95 & I-9 & $04 / 24 / 04$ & $<0.1$ \\
\hline $\mid-1$ & $10 / 09 / 06$ & $<0.1$ & $1-9$ & $10 / 23 / 04$ & $<0.1$ \\
\hline 1-2 & $07 / 02 / 03$ & 22.2 & $1-9$ & $10 / 10 / 06$ & 4.2 \\
\hline $1-2$ & $04 / 24 / 04$ & 2.96 & $1-10$ & $07 / 02 / 03$ & 5.93 \\
\hline $1-2$ & $10 / 09 / 06$ & $<0.1$ & $1-10$ & $04 / 24 / 04$ & $<0.1$ \\
\hline $1-3$ & $07 / 02 / 03$ & $<0.1$ & $1-10$ & $10 / 23 / 04$ & $<0.1$ \\
\hline $1-3$ & $04 / 24 / 04$ & $<0.1$ & $1-10$ & $10 / 10 / 06$ & 2.64 \\
\hline $1-3$ & $10 / 10 / 06$ & 6.9 & $1-11$ & $06 / 10 / 03$ & 23.4 \\
\hline $1-4$ & $07 / 02 / 03$ & 0.1 & $\mid-11$ & $04 / 24 / 04$ & 11.6 \\
\hline $1-4$ & $04 / 24 / 04$ & $<0.1$ & $\mid-11$ & $10 / 10 / 06$ & 0.71 \\
\hline $1-4$ & $10 / 10 / 06$ & 14.3 & $1-12$ & $06 / 10 / 03$ & $<0.1$ \\
\hline $1-5$ & $07 / 02 / 03$ & 7.65 & $1-12$ & $04 / 24 / 04$ & $<0.1$ \\
\hline $1-5$ & $04 / 24 / 04$ & 0.49 & $\mid-12$ & $10 / 10 / 06$ & $<0.1$ \\
\hline $1-5$ & $10 / 10 / 06$ & 18.1 & $1-13$ & $06 / 10 / 03$ & 6.33 \\
\hline$I-6$ & $07 / 02 / 03$ & 2.88 & $1-13$ & $04 / 24 / 04$ & 6.29 \\
\hline $1-6$ & $04 / 24 / 04$ & $<0.1$ & I-13 & $10 / 10 / 06$ & 0.4 \\
\hline $1-6$ & $10 / 23 / 04$ & 0.28 & $1-14$ & $06 / 10 / 03$ & $<0.1$ \\
\hline $1-6$ & $10 / 10 / 06$ & 0.29 & $1-14$ & $04 / 24 / 04$ & $<0.1$ \\
\hline $1-7$ & $07 / 02 / 03$ & 7.96 & $1-14$ & $10 / 10 / 06$ & $<0.1$ \\
\hline $1-7$ & $04 / 24 / 04$ & 4.73 & $1-15$ & $07 / 02 / 03$ & 6.06 \\
\hline $1-7$ & $10 / 23 / 04$ & 4.06 & $1-15$ & $04 / 24 / 04$ & $<0.1$ \\
\hline $1-7$ & $10 / 10 / 06$ & $<0.1$ & $I-15$ & $10 / 09 / 06$ & $<0.1$ \\
\hline $1-8$ & $07 / 02 / 03$ & $<0.1$ & $1-16$ & $07 / 02 / 03$ & 4.38 \\
\hline $1-8$ & $11 / 19 / 03$ & $7.17(5.91 \mathrm{D})$ & $1-16$ & $04 / 24 / 04$ & $<0.1$ \\
\hline $1-8$ & $04 / 24 / 04$ & 0.11 & $1-16$ & $10 / 09 / 06$ & $<0.1$ \\
\hline $1-8$ & $10 / 23 / 04$ & 0.59 & $\mid-17$ & $07 / 02 / 03$ & 0.13 \\
\hline $1-8$ & $05 / 17 / 05$ & 12.5 & $\mid-17$ & $04 / 24 / 04$ & $<0.1$ \\
\hline $1-8$ & $10 / 10 / 06$ & 0.5 & $1-17$ & $10 / 09 / 06$ & $<0.1$ \\
\hline
\end{tabular}

